Florida International University

FIU Digital Commons

$11-12-2020$

\title{
Production and Characterization of Twelve Different Biochars and Evaluating Their Effects on Soil Health and Plant Growth
}

Shagufta Gaffar

Florida International University, sgaff008@fiu.edu

Follow this and additional works at: https://digitalcommons.fiu.edu/etd

Part of the Agriculture Commons, Agronomy and Crop Sciences Commons, Environmental Health Commons, Environmental Microbiology and Microbial Ecology Commons, and the Environmental

Sciences Commons

\section{Recommended Citation}

Gaffar, Shagufta, "Production and Characterization of Twelve Different Biochars and Evaluating Their Effects on Soil Health and Plant Growth" (2020). FIU Electronic Theses and Dissertations. 4559.

https://digitalcommons.fiu.edu/etd/4559

This work is brought to you for free and open access by the University Graduate School at FIU Digital Commons. It has been accepted for inclusion in FIU Electronic Theses and Dissertations by an authorized administrator of FIU Digital Commons. For more information, please contact dcc@fiu.edu. 


\title{
FLORIDA INTERNATIONAL UNIVERSITY
}

Miami, Florida

\section{PRODUCTION AND CHARACTERIZATION OF TWELVE DIFFERENT BIOCHARS AND EVALUATING THEIR EFFECTS ON SOIL HEALTH AND PLANT GROWTH}

A dissertation submitted in partial fulfillment of

\author{
the requirements for the degree of \\ DOCTOR OF PHILOSOPHY \\ in \\ EARTH SYSTEMS SCIENCE \\ by
}

Shagufta Gaffar

2020 
To: Dean Michael R. Heithaus

College of Arts, Sciences and Education

This dissertation, written by Shagufta Gaffar, and entitled Production and Characterization of Twelve Different Biochars and Evaluating Their Effects on Soil Health and Plant Growth, having been approved in respect to style and intellectual content, is referred to you for judgment.

We have read this thesis and recommend that it be approved.

Leonard Scinto

Michael Ross

Yong Cai

Krishnaswamy Jayachandran, Major Professor

Date of Defense: November 12, 2020

The dissertation of Shagufta Gaffar is approved.

Dean Michael R. Heithaus
College of Arts, Sciences and Education

Andrés G. Gil

Vice President for Research and Economic Development and Dean of the University Graduate School

Florida International University, 2020 
(C) Copyright 2020 by Shagufta Gaffar

All rights reserved. 


\section{DEDICATION}

I dedicate this dissertation to my parents and my sister 


\section{ACKNOWLEDGMENTS}

I would like to take this opportunity to thank everyone who supported me in this journey to achieve my doctoral degree. I would like to begin by thanking my advisor, Dr. Krish Jayachandran for his advice, encouragement and patience. His mentorship helped me learn both on an academic and personal level.

I want to thank the members of my committee, Dr. Leonard Scinto, Dr. Michael Ross and Dr. Yong Cai for their interest in my research. I sincerely appreciate their time and suggestions for improving my dissertation. Special thanks to Dr. Scinto for letting me use his lab for sample analysis.

I would like to thank Dr. Jeff Novak and Don Watts from USDA-ARS, South Carolina, for helping me making the biochars without which the research would have not been possible.

I would also like to thank Dr. Rosemary Hickey-Vargas to allow me to use the inductively coupled plasma- optical emission spectroscopy (ICP-OES) instrument in her lab. I am grateful to Dr. Saoli Chanda for teaching me how to run the spectrometer and for all the conversations I had with her regarding research and life.

I want to thank Herma Pierre, graduate from Florida International University, who took time to train me in using the High performance liquid chromatography (HPLC) instrument. Thanks to Mark Kershaw from the Institute of Environment at FIU for helping me run my samples in the HPLC. 
My immense gratitude to FIU Agroecology graduate Clara Riquelme, for her endless time, hard work and support during my garden research project. She was there even over the weekends to help with the experiments. I do not think it would have been possible to successfully complete the project without her.

I cannot but thank Franco Tobias and Rafael Travieso from the Gaiser lab for letting me borrow tools to prepare my plant samples for analysis.

A huge hearted thanks to my fellow graduate students, staff and faculty at the Agroecology program for their support and help throughout this journey.

My deepest appreciation to all my friends here in Miami and in USA who made me feel like I was at home. I want to thank my parents, my sister and my friends abroad for their support and encouragement.

Finally, I would like to thank the Department of Earth and Environment for the support through the Graduate Teaching Assistantship. 


\begin{abstract}
OF THE DISSERTATION
PRODUCTION AND CHARACTERIZATION OF TWELVE DIFFERENT

BIOCHARS AND EVALUATING THEIR EFFECTS ON SOIL HEALTH AND

PLANT GROWTH

by

Shagufta Gaffar
\end{abstract}

Florida International University, 2020

Miami, Florida

Professor Krishnaswamy Jayachandran, Major Professor

Biochar has been a topic of growing interest in the scientific community. It is a product derived from carbon rich organic materials through the process of pyrolysis. It has received wide attention as a means to improve soil fertility and crop productivity, absorb pollutants in soil, and sequester carbon to mitigate climate change. Recent research on biochar explores its impacts on the environment with particular focus on use as a soil amendment in agriculture. The variation in biomass type and production temperature influences the variation in the environmental and agronomic outcomes of biochar application which makes it possible to design biochar with specific properties to achieve desired goals. Therefore, the advanced understanding of biochar is of utmost importance. The present research was aimed to produce and characterize twelve biochars from feedstocks consisting of invasive plant species along with native plants and agricultural residues made at two different production temperatures. Furthermore, the present study explored the potential of these biochars as amendments to remove pesticide from soil, thus reducing further groundwater pollution. The effects of the biochars on plant growth, soil 
microbial population and soil enzyme activities were also investigated. Laboratory studies were conducted to characterize the biochars and also to evaluate their effect on pesticide retention. A study of potted plants was done to observe how biochars influenced plant growth as well as soil microbial and enzyme activities. Results indicated that the production temperatures and type of feedstocks greatly influenced the physicochemical properties of the biochars which subsequently affected their performance. It was found that the type of feedstocks had greater effects on biochar performance than the selected production temperatures. The knowledge from the study will be beneficial to determine the integration of these biochars as an approach towards sustainable agricultural practice and in climate mitigation. 


\section{TABLE OF CONTENTS}

\section{CHAPTER}

PAGE

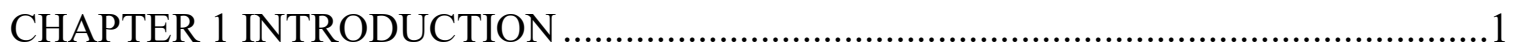

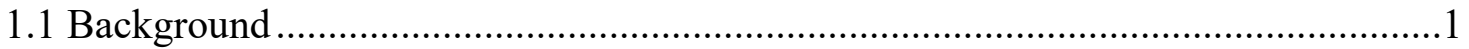

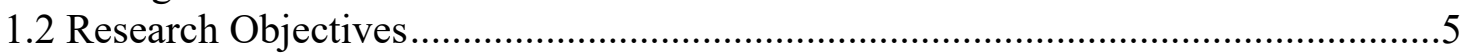

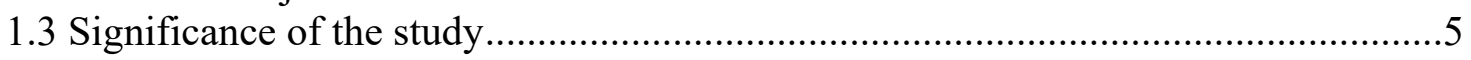

CHAPTER 2 PRODUCTION AND CHARACTERIZATION OF BIOCHARS ................7

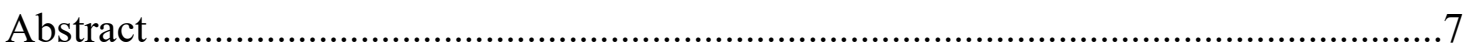

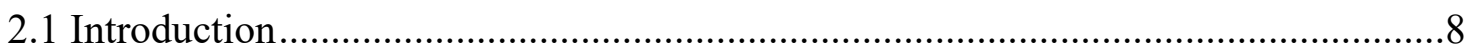

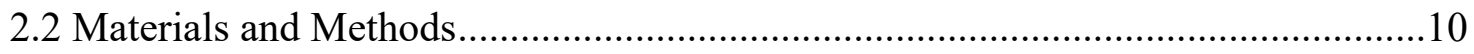

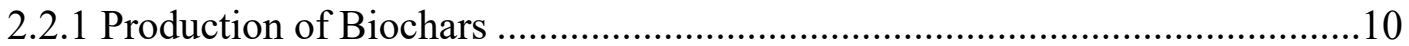

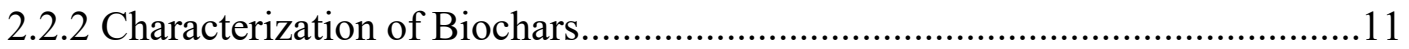

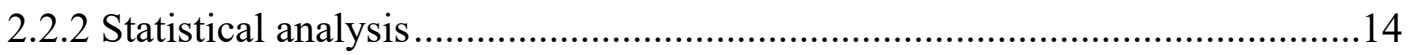

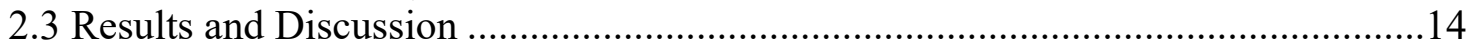

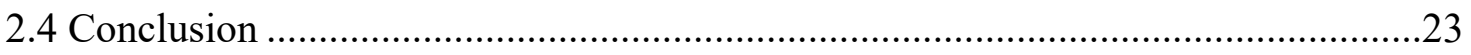

CHAPTER 3: EFFECT OF DIFFERENT BIOCHARS ON THE ADSORPTION

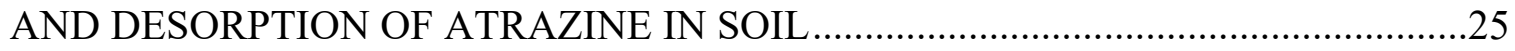

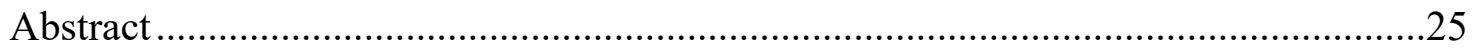

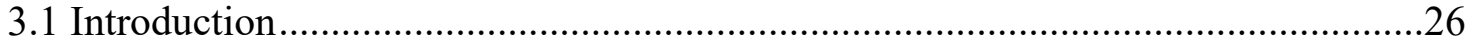

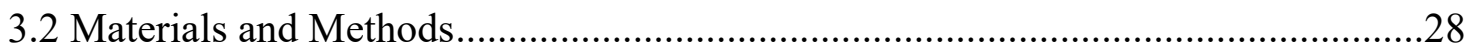

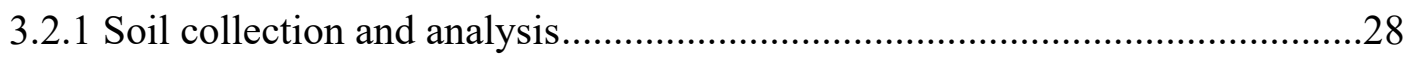

3.2.2 Properties of chemicals used in this study ..................................................29

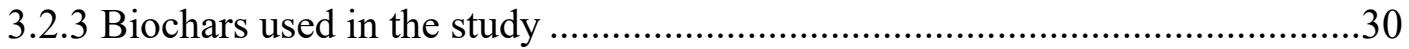

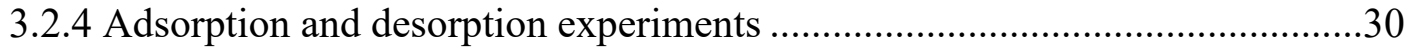

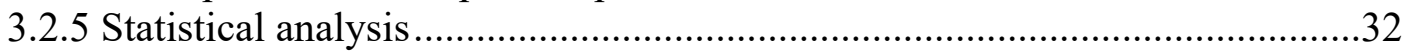

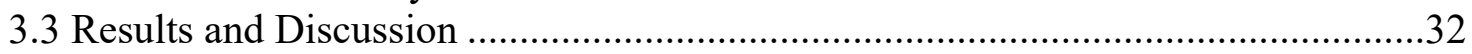

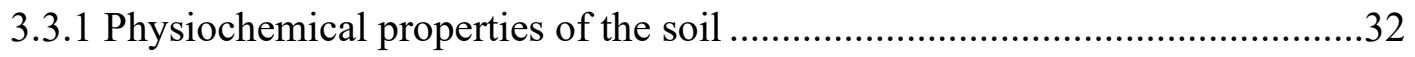

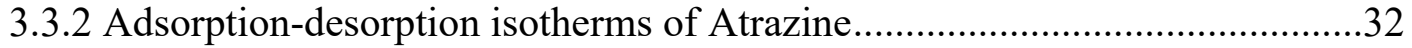

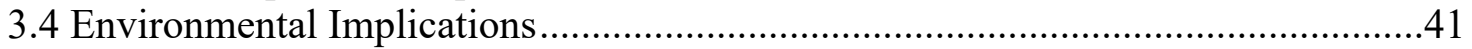

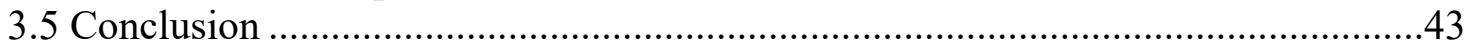

CHAPTER 4: INVESTIGATING THE EFFECT OF TWELVE DIFFERENT BIOCHARS ON THE GROWTH OF Capsicum annuum 'JALAPENO', SOIL MICROBIAL POPULATION, AND ENZYME ACTIVITY ………………..................45

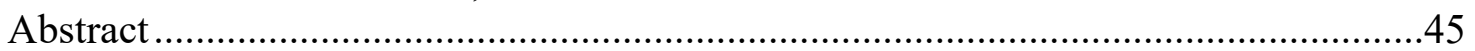

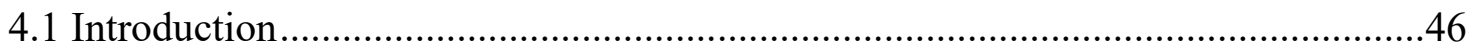

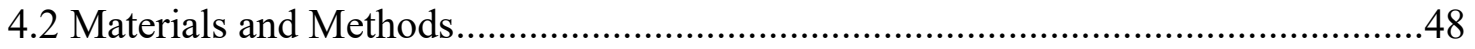

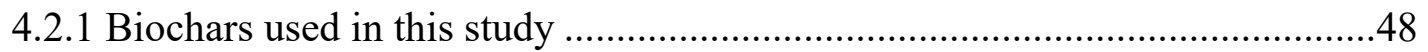

4.2.2 Site description and Experimental design ....................................................4

4.2.3 Soil collection and preparation ..................................................................... 
4.2.4 Potted plant experiment and plant parameter analysis ..............................52

4.2.5 Enumeration of soil microbial population ..................................................53

4.2.6 Estimation of arbuscular mycorrhizal (AM) fungi root colonization ...............53

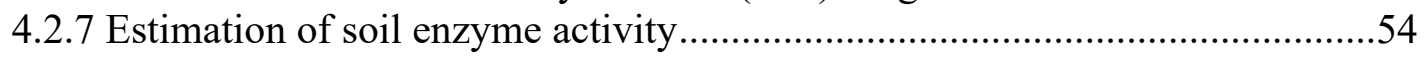

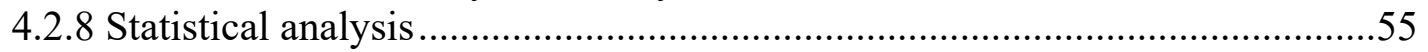

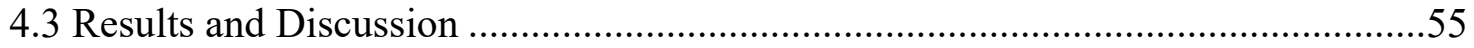

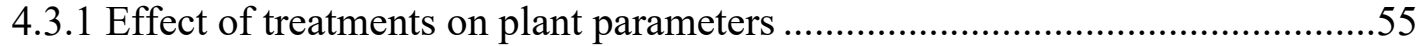

4.3.2 Enumeration of soil microbial population .................................................61

4.3.3 Estimation of root colonization by arbuscular mycorrhizal (AM) fungi .........66

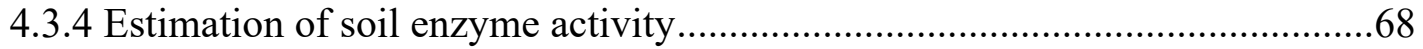

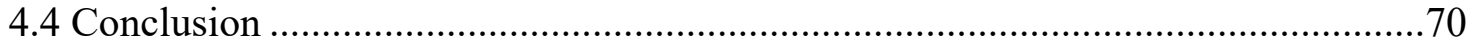

CHAPTER 5 SUMMARY AND CONCLUSION …................................................ 71

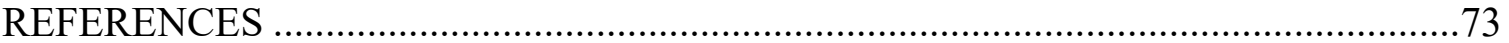

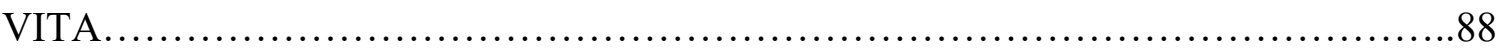




\section{LIST OF TABLES}

TABLE

PAGE

Table 2. 1 Yield, proximate analysis and selected physicochemical properties of the twelve different biochars made at two production temperatures. 16

Table 2. 2 Elemental composition and atomic ratio of the twelve different biochars. ..... 17

Table 3. 1 Physical and chemical properties of soil................................................ 29

Table 3. 2 Adsorption parameters for atrazine in unamended soil and soils amended with the twelve different biochars at $2 \%(\mathrm{w} / \mathrm{w})$

Table 3. 3 Desorption parameters for atrazine in unamended soil and soils amended with the twelve different biochars at $2 \%(\mathrm{w} / \mathrm{w})$

Table 4. 1 Selected physicochemical properties of the twelve different biochars used as treatments for the pot experiments.

Table 4. 2 The $p$ values for the main and interaction effect on treatment and sampling time for plant height, leaf number and SPAD values for Capsicum annuum 'Jalapeno' during the entire growing season.

Table 4. 3 Effect of different treatments on plant leaf, branch, shoot and root dry weight, fruit number and fruit fresh weight.

Table 4. 4 The $p$ values for the main and interaction effect on treatment and sampling time for bacterial and fungal population in soil.

Table 4. 5 Effect of different treatments on arbuscular mycorrhizal (AM) fungi root colonization during Capsicum annuum 'Jalapeno' production.

Table 4. 6 The $p$ values for the effect of different treatments on the $\beta$-1-4-glucisidase (for carbon), $\beta$-N-acetylglucosaminidase (for nitrogen), and alkaline phosphatase (for phosphorus) enzyme activities in soil. 


\section{LIST OF FIGURES}

\section{FIGURE}

PAGE

Figure 1. 1 Different Types of Biochars with feedstocks (Online image). Major, J. (2008). https://biochar-international.org/biochar-feedstocks/ 2

Figure 1. 2 Biochar as a potential carbon negative technology (Online image). Biochar Solutions Inc. (2011). https://images.app.goo.gl/De7jmBSN5S7cFuT87.... 3

Figure 1. 3 Benefits from Biochar (Online image). Tylor, P. (2015)............................ 3

Figure 2. 1 Images of the twelve different biochars; AP350 \& AP500 = Australian pine derive biochar pyrolyzed at $350^{\circ} \mathrm{C}$ and $500^{\circ} \mathrm{C}, \mathrm{BP} 350 \& \mathrm{BP} 500=$ Brazilian pepper derived biochar pyrolyzed at $350^{\circ} \mathrm{C}$ and $500^{\circ} \mathrm{C}, \mathrm{CH} 350 \& \mathrm{CH} 500=$ Coconut husk derived biochar pyrolyzed at $350^{\circ} \mathrm{C}$ and $500^{\circ} \mathrm{C}, \mathrm{Cy} 350 \&$ Cy500 $=$ Cypress derived biochar pyrolyzed at $350^{\circ} \mathrm{C}$ and $500^{\circ} \mathrm{C}, \mathrm{L} 350 \& \mathrm{~L} 500=$ Loblolly pine derived biochar pyrolyzed at $350^{\circ} \mathrm{C}$ and $500^{\circ} \mathrm{C}, \mathrm{P} 350 \& \mathrm{P} 500=$ Pecan shell derived biochar pyrolyzed at $350^{\circ} \mathrm{C}$ and $500^{\circ} \mathrm{C}$.

Figure 2. 2 Principal component analysis of the parameters measured for the characterization of biochars. PC1 explains $48 \%$ of the variance which is mainly a combination of $\mathrm{O}$ content $(\%), \mathrm{O} / \mathrm{C}$ and $(\mathrm{N}+\mathrm{O}) / \mathrm{C}$ ratios. $\mathrm{PC} 2$ in mainly a combination of $\mathrm{pH}$ and ash content (\%) and explains $21 \%$ of the variance.

Figure 2. 3 Hierarchical cluster analysis of the biochars based on the parameters from principal component analysis. Biochars with similar characteristics are clustered together. Sample abbreviations are the same as in Figure 2.1.

Figure 3. 1 The adsorption-desorption isotherms for atrazine calculated in soil without biochar.

Figure 3. 2 The adsorption-desorption isotherms for atrazine calculated in soil amended with the twelve different biochars at $2 \%(\mathrm{w} / \mathrm{w})$. AP350 \& AP500 = Australian pine derived biochar pyrolyzed at $350^{\circ} \mathrm{C}$ and $500^{\circ} \mathrm{C}, \mathrm{BP} 350 \& \mathrm{BP} 500=$ Brazilian pepper derived biochar pyrolyzed at $350^{\circ} \mathrm{C}$ and $500^{\circ} \mathrm{C}, \mathrm{CH} 350 \& \mathrm{CH} 500=$ Coconut husk derived biochar pyrolyzed at $350^{\circ} \mathrm{C}$ and $500^{\circ} \mathrm{C}, \mathrm{Cy} 350 \& \mathrm{Cy} 500=$ Cypress derived biochar pyrolyzed at $350^{\circ} \mathrm{C}$ and $500^{\circ} \mathrm{C}, \mathrm{L} 350 \& \mathrm{~L} 500=$ Loblolly pine derived biochar pyrolyzed at $350^{\circ} \mathrm{C}$ and $500^{\circ} \mathrm{C}, \mathrm{P} 350 \& \mathrm{P} 500=$ Pecan shell derived biochar pyrolyzed at $350^{\circ} \mathrm{C}$ and $500^{\circ} \mathrm{C}$. 
Figure 4. 1 Experimental layout of the shade house experiment

Figure 4. 2 Effect of different treatments on (a) plant height and (b) number of leaves throughout the growing season of Capsicum annuum 'Jalapeno'. Treatment abbreviations are the same as in Figure 4.1. Error bar represents standard error of mean values. WAP $=$ Weeks after planting.

Figure 4. 3 Comparison of soil plant analysis development (SPAD) chlorophyll meter value of the leaves throughout the growing season of Capsicum annuum 'Jalapeno'. Treatment abbreviations are the same as in Figure 4.1. Error bar represents standard error of mean values. WAP $=$ Weeks after planting.

Figure 4. 4 Effect of different treatments on (a) bacteria and (b) fungi population in soil 40 days and 90 days after plating Capsicum annuum 'Jalapeno' based on dilution plate counts. Treatment abbreviations are the same as in Figure 4.1. DAP = Days after planting.

Figure 4. 5 Effect of different treatments on $\beta$-1-4-glucisidase, $\beta$-Nacetylglucosaminidase, and alkaline phosphatase enzyme activities in soil using the fluorescent model substrate 4-methylumbelliferone (MUF) assay. Treatment abbreviations are the same as in Figure 4.1. 


\section{ABBREVIATIONS AND ACRONYMS}

$\begin{array}{ll}\text { ASTM } & \text { American Society for Testing and Materials } \\ \text { ATSRD } & \text { Agency for toxic Substances and Disease Registry Brunauer- } \\ \text { BET } & \text { Emmett-Teller } \\ \text { CEC } & \text { Cation Exchange Capacity } \\ \text { CMA } & \text { Corn Meal Agar } \\ \text { HOCs } & \text { Hydrophobic Organic Compounds } \\ \text { HPLC } & \text { High Performance Liquid Chromatography } \\ \text { ICP-OES } & \text { Inductively Coupled Plasma- Optical Emission Spectroscopy Loss } \\ \text { LOI } & \text { On Ignition } \\ \text { OC } & \text { Organic Carbon } \\ \text { OM SSA } & \text { Organic Matter } \\ \text { TPV TSA } & \text { Specific Surface Area } \\ & \text { Total Pore Volume } \\ & \text { Tryptic Soy Agar }\end{array}$




\section{CHAPTER 1 INTRODUCTION}

\subsection{Background}

Recently in the scientific community biochar has been a topic of growing interest. It is a product derived from organic materials rich in carbon. Biochar has the potential as a soil conditioner for carbon sequestration, waste management and energy production. Research on biochar explores its impacts on the environment with particular focus on use as a soil amendment in agriculture. Knowledge of biochar came from the 'Terra Preta' soils in the Amazon, where the practice of slashing and charring forest trees and other biomass led to the development of the dark and fertile soil along with the capacity for long lasting carbon storage (Sombroek et al., 2003; O’Neill et al., 2009).

Biochar is obtained through the process of pyrolysis which involves thermal and chemical decomposition of biomass in limited or zero supply of oxygen. It is one of the products of pyrolysis that yields a surplus of energy as heat or biofuel. The type of feedstock, pyrolysis temperature, and method of pyrolysis cause variation in the composition of biochars (Ippolito et al., 2012). A variety of biomass types have been successfully used for biochar production consisting of agricultural and forestry by-products (such as straw, nut shells, rice hulls, wood chips, wood pellets, tree bark, and switch grass), industrial by-products (such as bagasse from the sugarcane industry, paper sludge, and pulp), animal wastes (such as chicken litter, dairy and swine manure), and sewage sludge (Mylavarapu et al., 2013) (Figure 1.1). The use of organic waste and agricultural residue as potential feedstocks for biochar production can be an effective strategy for waste management. 


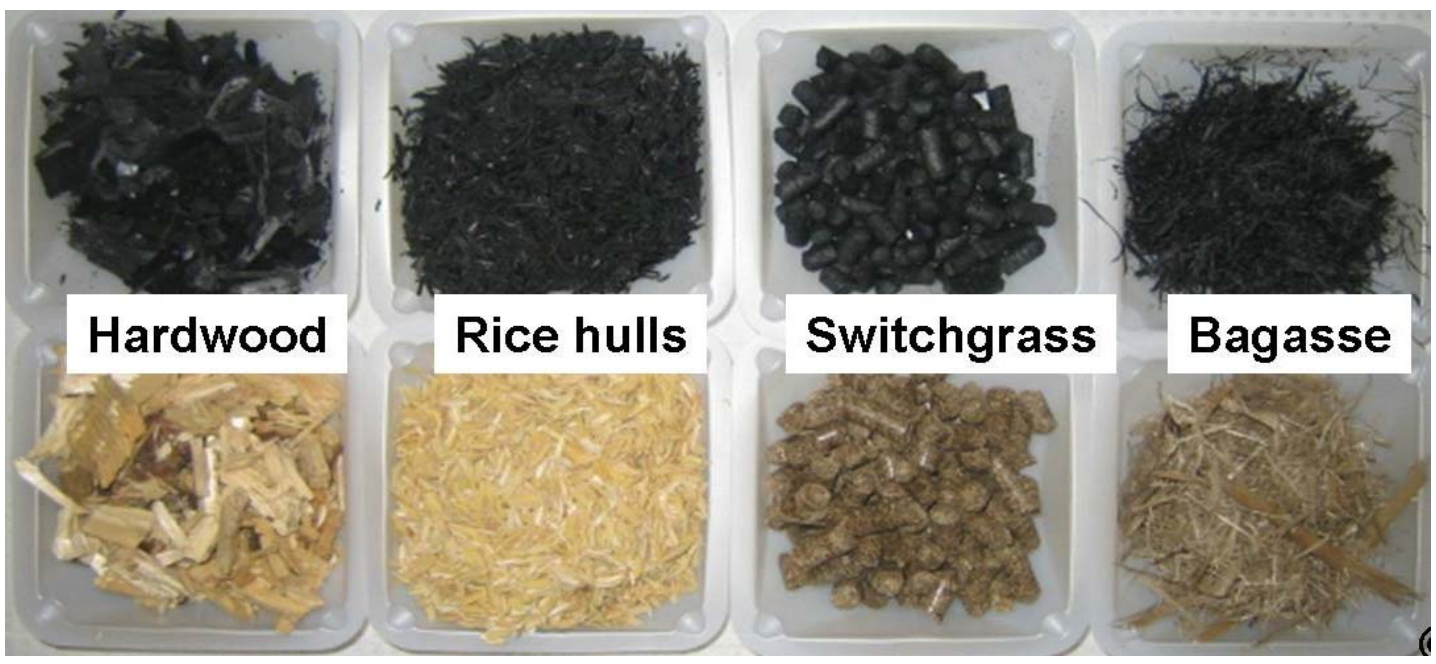

Figure 1. 1 Different Types of Biochars with feedstocks (Online image). Major, J. (2008). https://biocharinternational.org/biochar-feedstocks/

Burning fossil fuels, excessive tillage in agricultural fields and destruction of forests have resulted in the movement of carbon from the lithosphere and biosphere to the atmosphere faster than photosynthesis can remove it, such processes are therefore carbon positive (Lehman et. al., 2006). Approximately 15\% of the total global greenhouse gas emissions can be attributed to agriculture (Baumert, 2005). However, this is only a calculation for direct emissions, such as nitrous oxide, carbon dioxide, and methane. Indirect emissions from agriculture are estimated to be an additional 12\% (Scialabba et al., 2010). Approximately 600 million to 1 billion metric tons of carbon can be sequestered annually through the restoration of degraded soils (Lal and Bruce, 1999). Biochar has the potential to be carbon negative, that is its production and application have the potential to turn the carbon dioxide removed from the atmosphere by plants into a solid carbon that will stay solid (and out of the atmosphere) for a sufficiently long time (Lehman et. al., 2006) (Figure 1.2). Biochar is considered extremely stable and may remain in soils for long 
periods of time, estimated between one hundred to several thousand years (Novak et al., 2009).
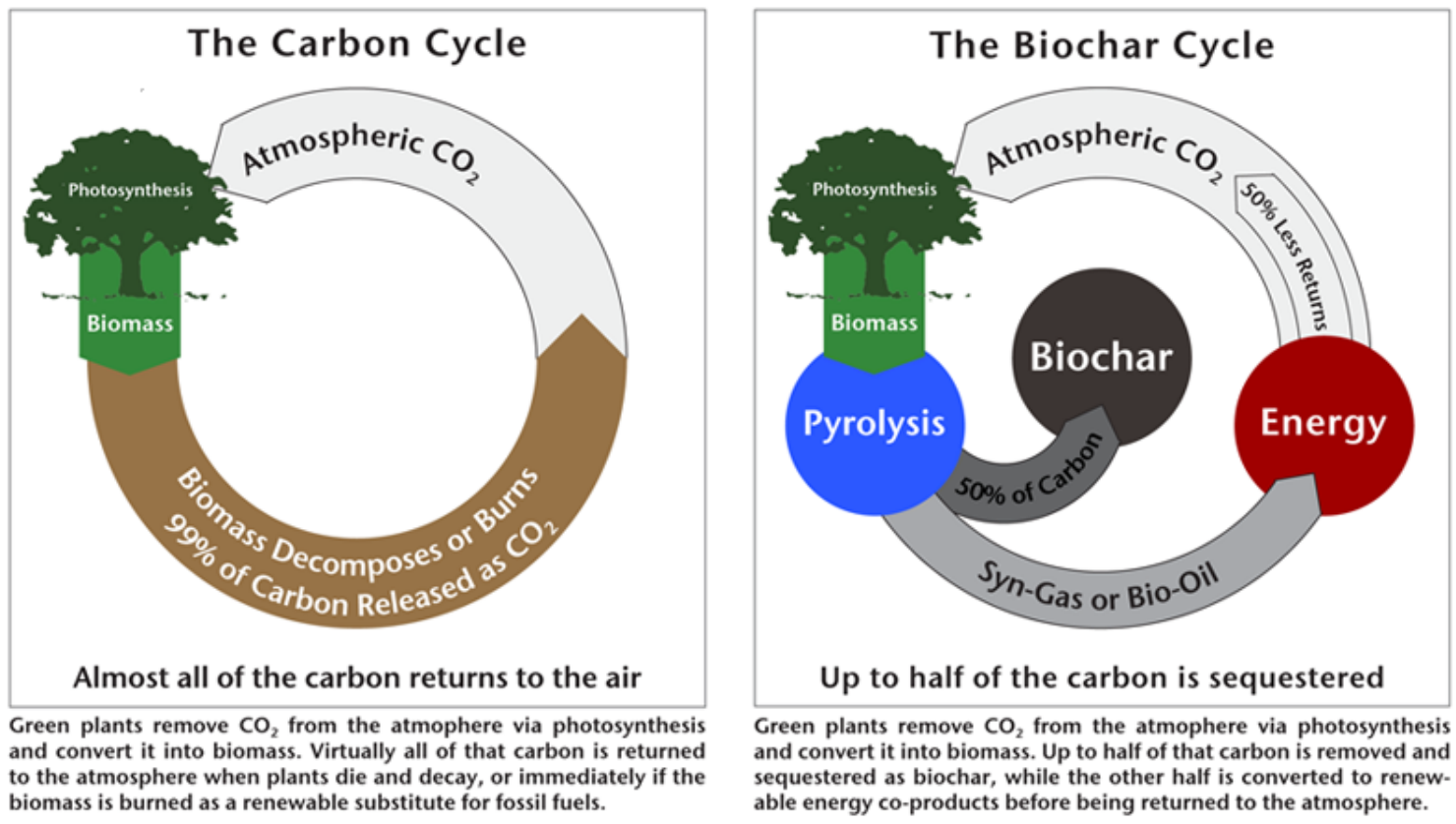

Figure 1. 2 Biochar as a potential carbon negative technology (Online image). Biochar Solutions Inc. (2011). https://images.app.goo.gl/De7jmBSN5S7cFuT87

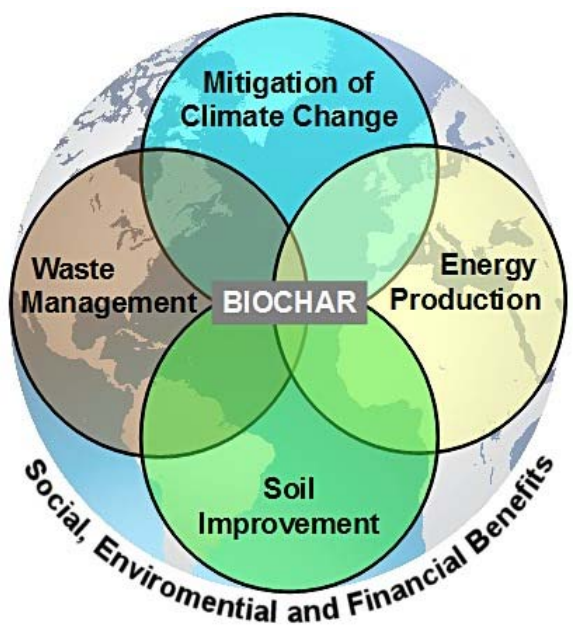

Figure 1. 3 Benefits from Biochar (Online image). Tylor, P. (2015).

https://deepgreenpermaculture.com/2015/03/15/biochar-ancient-origins-modern-inspirations/ 
Benefits from amending soils with biochar are multidimensional (Figure 1.3). These benefits include minimizing nitrous oxide and methane emissions, minimizing leaching of nutrients to groundwater, and reducing contaminant levels in soil (Lehmann et al., 2006; Glaser et al., 2009; Spokas et al., 2009; McHenry, 2010; Mylavarapu et al. 2013; Fidel et al., 2019). The net greenhouse gas (GHG) impact associated with biochar application to soil is influenced by the process and type of biochar produced as well as the soil condition (Ippolito et al., 2012). Kammann et al. (2012) showed that peanut hull biochar produced at high temperatures caused less release of $\mathrm{CO}_{2}, \mathrm{~N}_{2} \mathrm{O}$, and $\mathrm{CH}_{4}$ compared to those produced at low temperatures. Furthermore, pyrolysed products are protected from rapid microbial degradation allowing secure sequestration of carbon, thereby offering substantial potential for mitigation of greenhouse gas emissions (Lehmann et al., 2006; Spokas et al., 2009). Biochar has the ability to influence soil nutrient availability and crop production (Graber et al., 2010; Major et al., 2010), and soil microbial activity (Warnock et al., 2007; Steiner et al., 2008). A recent review of biochar articles by Spokas et al. (2012) stated that application of biochars have led to positive results in agricultural production. Although there have been some reports of no crop yield benefits (Schnell et al. 2012; de Malo Carvalho et al., 2013; Tammeorg et al., 2014) or even negative yield responses (Ippolito et al. 2012; Velez et al., 2018). Therefore, it is important to understand how biochars can influence crop yield. These multidimensional outcomes have triggered interest in the combined use of biochar for soil fertility improvement and carbon sequestration. 


\subsection{Research Objectives}

The purpose of my research was to produce and characterize biochars and to investigate their potentiality in reducing water pollution by removing pesticide from the soil, and to further observe their effects on plant growth, soil microbial population and enzyme activities as an soil amendment in agricultural setting.

The specific objectives were

$>$ To produce and characterize twelve biochars made from six different feedstocks consisting of invasive plant species along with native plants and agricultural residues at two different production temperatures

$>$ To evaluate the potential of these biochars in effectively removing Atrazine (pesticide) from the soil

To observe how these biochars can influence Jalapeno pepper plant growth and yield

$>$ To investigate the influence of these biochars on soil bacteria and fungi population, root colonization by arbuscular mycorrhizal fungi and enzyme activities in soil

\subsection{Significance of the study}

In the current agricultural scenario, where certain practices accidentally lead to the damage the on the environment, it is critical to find ways to mitigate problems and protect the environment while assuring food security. Biochar has the potential to improve soil quality that can promote food production along with improving the environment. The variation in biomass type and production temperature influences the variation in the environmental and agronomic outcomes of biochar application which is further affected by the type of soil, plants and climatic conditions. The first and crucial step to understanding 
biochar behavior relies on the knowledge of biochar properties which is possible to achieve through their careful characterization. From there, it is possible to evaluate the environmental and agronomic impacts of biochar applications. Limited information is available on the use of invasive plant species as feedstocks for potential biochar production and their influence on pesticide retention, plant growth and soil microbial population. The main purpose of the present study was to include invasive plant species along with native plants and agricultural residues as potential feedstocks for biochar production as an effective strategy towards waste management and to evaluate the performance of these biochar applications in agricultural settings. Results from the current study will be beneficial to determine the integration of these biochars as successful amendments in agricultural management strategies. 


\title{
CHAPTER 2 PRODUCTION AND CHARACTERIZATION OF BIOCHARS
}

\begin{abstract}
\end{abstract}
Application of biochar to soils have the potential to improve crop growth and the quality of the environment including soil conditions. The properties of biochar greatly influence their performance and the type of feedstocks and pyrolysis temperature impact the biochar properties. The present study was conducted to produce and characterize biochars made from diverse feedstocks at different pyrolysis temperatures that can help to determine their potential use. Twelve biochars were made from six different feedstocks consisting of Australian pine (Casaurina equisetifolia), Brazilian pepper (Schinus terebinthifolius), coconut husk (Cocos nusifera), cypress (Taxodium distichum), loblolly pine (Pinus taeda), and pecan shell (Carya illinoinensis) which were pyrolyzed at temperatures $350^{\circ} \mathrm{C}$ and $500^{\circ} \mathrm{C}$. The biochars were categorized on the basis of the feedstock and production temperatures. The ash content (50\%), fixed carbon content $(70 \%)$, and $\mathrm{pH}(10 \%)$ of the biochars significantly $(p<0.05)$ increased with increasing pyrolysis temperature. An increase in total carbon content, specific surface area (SSA) and total pore volume (TPV) of the biochars were also observed at higher temperature. As the temperature increased from $350^{\circ} \mathrm{C}$ to $500^{\circ} \mathrm{C}$ the moisture content and volatile matter (VM) content of the biochars decreased significantly $(p<0.05)$ whereas the decrease in cation exchange capacity (CEC) and average pore size of the biochars were not significant. Coconut husk produced biochars that had higher VM content (12-21\%), moisture content (3.5-9.5\%), $\mathrm{pH}(8-30 \%)$, and CEC (16-163\%) than the biochars made from the remaining five feedstocks. 


\subsection{Introduction}

Biochar is the carbonaceous solid residue obtained by pyrolysis. The process of pyrolysis involves thermal and chemical decomposition of biomass in limited or zero supply of oxygen. Biochar is typically produced at temperatures between $300^{\circ} \mathrm{C}-1000^{\circ} \mathrm{C}$ (Glaser et al., 2001). Three products are generated at varying amounts during the pyrolysis process: solid (char and/or ash), liquid (bio-oil or tar) and gas (syngas or producer gas). Depending on the product quantity and quality goals, each process uses different reaction conditions (temperature, pressure, heating rate, residence time, reactive or inert atmosphere, purge gas flow rate, etc) to optimize the production of one or more specific products (Ippolito et al., 2012). The type of biomass, pyrolytic process, and pyrolytic conditions influence the properties of the resulting biochars and biochar properties influence the environmental and agronomic impacts of biochar applications (Ippolito et al., 2012). Biochars with a highly aromatic composition may best be suited for long-term carbon sequestration because of their recalcitrant nature (Warnock et al., 2007). The degree of aromatic condensation in biochars is believed to be related to recalcitrance in the environment, carbons in dense aromatic structures are more resistant to oxidation and few microorganisms have enzymes capable of breaking down such bonds (Warnock et al., 2007). In general, the high the pyrolysis temperatures biochar with carbon in a stable form. Biochar with large amounts of carbon in poly-condensed aromatic structures is obtained by pyrolyzing organic feedstocks at high temperatures $\left(500^{\circ} \mathrm{C}\right.$ to $\left.700^{\circ} \mathrm{C}\right)$, but also have fewer ion exchange functional groups as a result of dehydration and decarboxylation, potentially limiting their usefulness for retaining soil nutrients sufficient for enhanced crop growth. Biochars produced at low temperatures have been considered more suitable as soil conditioners. At 
low temperatures $\left(250^{\circ} \mathrm{C}\right.$ to $\left.400^{\circ} \mathrm{C}\right)$ biochars have high yield recoveries and contain more $\mathrm{C}=\mathrm{O}$ and $\mathrm{C}-\mathrm{H}$ functional groups that can serve as nutrient exchange sites after oxidation.

Biochars can be made from the thermochemical processing of almost any carbonaceous material. One contributing factor to the feedstock variety is the desire to use locally available agricultural residues. The use of materials including agricultural wastes, forestry residues, dead biomass, urban yard waste, municipal solid wastes, etc. that do not compete with food production and would otherwise decompose must be taken into consideration as potential feedstocks for the sustainable production of biochar (Lehman et. al., 2006; Mylavarapu et al., 2013). Invasive plant species are often considered as a great threat to the agricultural ecosystem by competing with native species for resources and even altering the chemical properties of the soil where they grow. A recent report indicated that the U.S. alone spends about $\$ 3$ billion in an effort to prevent, control, and eradicate invasive plant species (Johnson et al., 2017). A major problem in dealing with invasive species, in addition to the cost involved in their management, has to do with their removal, extraction, and the sustainable management of the waste (residual) products. Application of biochar made from invasive plants can be an incentive to deal with these noxious plants (such as Casaurina equisetifolia, Schinus terebinthifolius, Melaleuca quinquenervia, etc.) in a profitable way. Moreover, the high temperature of the pyrolysis process can sterilize the invasive plants which can contribute to preventing further spread of these biological pollutants.

The characterization of biochars is an important initial step to understand the production specifics and application mechanisms in the environment including soil systems. A number of techniques have been used to characterize biochars. Use of some 
form of proximate analysis is prevalent in biochar literature which is used to differentiate between volatile and fixed carbon. The proximate analysis is a thermogravimetric method traditionally considered the most basic for determining char quality where moisture, volatile matter, ash and fixed carbon content are analyzed. The second most common analysis and one that is critical to further characterizations is the measurement of carbon, hydrogen, oxygen and nitrogen content, also known as elemental analysis. One way of measuring the degree of aromaticity is from the oxygen to carbon ratio $(\mathrm{O} / \mathrm{C})$ and hydrogen to carbon ratio $(\mathrm{H} / \mathrm{C})$. The total or ultimate analysis of a char includes information from both the elemental and the proximate analysis. Since $\mathrm{pH}$ affects so many physical, chemical and biological properties of soil, being able to predict the $\mathrm{pH}$ effects of biochar is critical to choosing the right biochar for the right application. It is also important to determine the cation exchange capacity (CEC) of biochars for studies related to nutrient as well as organic and inorganic pollutants in soil.

The objective of the current study was to combine invasive plant species with native plants and agricultural residues as potential feedstocks for biochar production and characterize twelve different biochars made from a total of six different feedstocks at two different temperatures.

2.2 Materials and Methods

\subsubsection{Production of Biochars}

A total of twelve biochars were produced from six different feedstocks which included Australian pine (Casaurina equisetifolia), Brazilian pepper (Schinus terebinthifolius), coconut husk (Cocos nusifera), cypress (Taxodium distichum), loblolly pine (Pinus taeda), and pecan shell (Carya illinoinensis) at temperatures $350^{\circ} \mathrm{C}$ and $500^{\circ} \mathrm{C}$ 
(Figure 2.1). The biochars were pyrolyzed at the USDA-ARS station in Florence, South Carolina, USA. Australian pine and Brazilian pepper are invasive plant species in South Florida which have been listed on the Florida's Noxious Weed list (UF-IFAS, 2012). These two feedstocks were collected from Possum Trot located in Miami, Florida, USA. Coconut was collected from LNB farm also located in Miami and the husk was separated at the laboratory in Florida International University (FIU). Loblolly pine and cypress are native to the southeastern United States. These feedstocks along with pecan shell were provided by USDA-ARS at Florence, South Carolina. Pecan shell and coconut husk were selected as feedstocks from agricultural residues. All feedstocks were oven dried at $70^{\circ} \mathrm{C}$ for 24 hours prior to pyrolyzing. The biochars were denoted on the basis of the feedstock and production temperature, for instance, AP350 indicated Australian pine derived biochar pyrolyzed at $350^{\circ} \mathrm{C}$ or AP500 indicated Australian pine derived biochar pyrolyzed at $500^{\circ} \mathrm{C}$ and so on.

\subsubsection{Characterization of Biochars}

Biochar yield, defined as the amount of biochar produced at each pyrolysis temperatures, was calculated as:

$$
\text { Biochar Yield }(\%)=\left(M_{\text {Biochar }} / M_{\text {Feedstock }}\right) \times 100
$$

where, MBiochar is the mass ( $\mathrm{g}$ ) of biochar and Mreedstock is the mass ( $\mathrm{g}$ ) of feedstock, both on a basis of dry weight. Proximate analysis, a combination of moisture, volatile matter (VM), ash, and fixed carbon (C) content of the biochar, used to measure char quality was conducted following the ASTM proximate analysis method for wood charcoals (ASTM D1762-84, 2007) in the laboratories at FIU using a Fisher Scientific isotemp muffle furnace. 


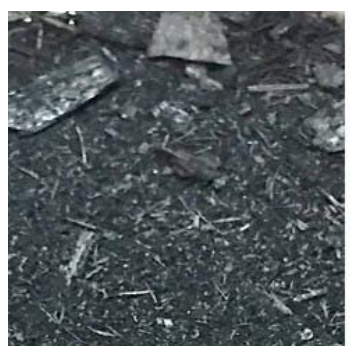

AP350

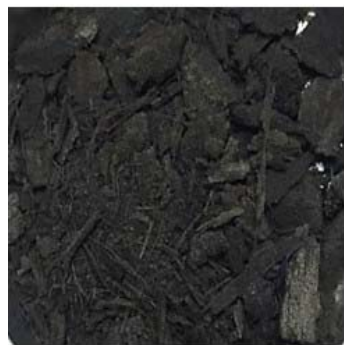

CH350

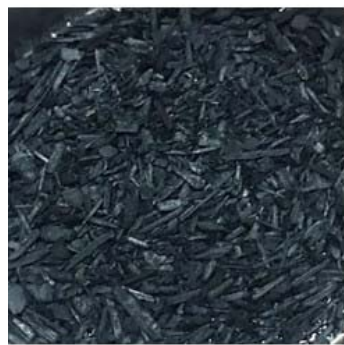

L350

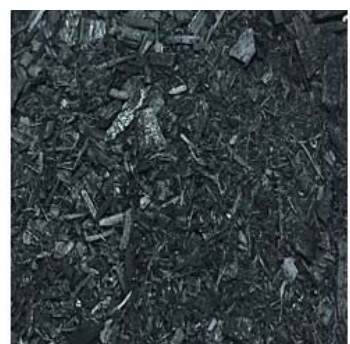

AP500

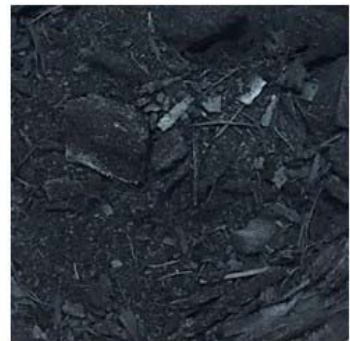

$\mathbf{C H 5 0 0}$

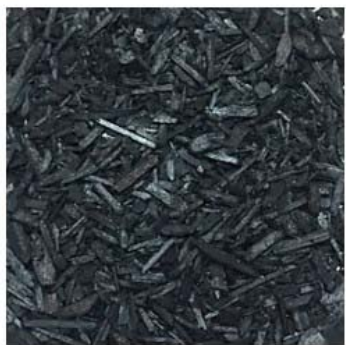

L500

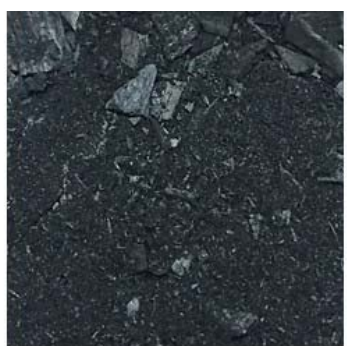

BP350

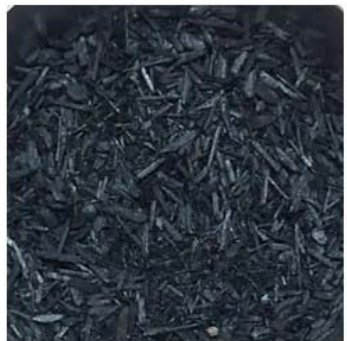

Cy350

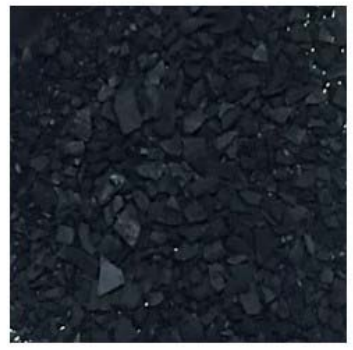

P350

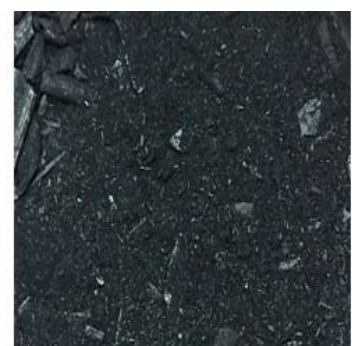

BP500

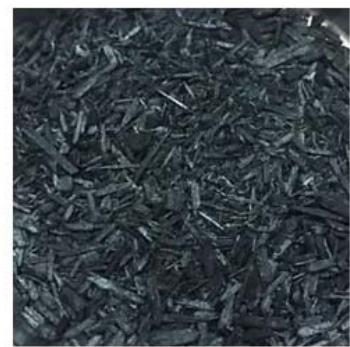

Cy500

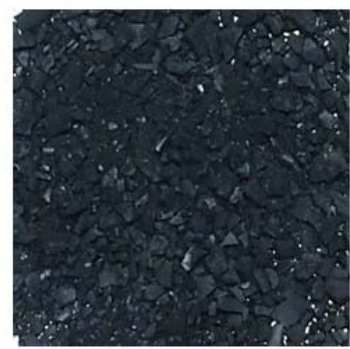

P500

Figure 2. 1 Images of the twelve different biochars; AP350 \& AP500 = Australian pine derive biochar pyrolyzed at $350^{\circ} \mathrm{C}$ and $500^{\circ} \mathrm{C}, \mathrm{BP} 350 \& \mathrm{BP} 500=$ Brazilian pepper derived biochar pyrolyzed at $350^{\circ} \mathrm{C}$ and $500^{\circ} \mathrm{C}, \mathrm{CH} 350 \& \mathrm{CH} 500=$ Coconut husk derived biochar pyrolyzed at $350^{\circ} \mathrm{C}$ and $500^{\circ} \mathrm{C}, \mathrm{Cy} 350 \& \mathrm{Cy} 500$ $=$ Cypress derived biochar pyrolyzed at $350^{\circ} \mathrm{C}$ and $500^{\circ} \mathrm{C}, \mathrm{L} 350 \&$ L500 $=$ Loblolly pine derived biochar pyrolyzed at $350^{\circ} \mathrm{C}$ and $500^{\circ} \mathrm{C}, \mathrm{P} 350 \& \mathrm{P} 500=$ Pecan shell derived biochar pyrolyzed at $350^{\circ} \mathrm{C}$ and $500^{\circ} \mathrm{C}$.

Moisture was measured as the mass lost at $105^{\circ} \mathrm{C}$. Approximately $1.0 \mathrm{~g}$ of ground biochar sample was taken in pre-weighed crucible cups and placed in the muffle furnace at $105^{\circ} \mathrm{C}$ for 2 hours. The crucibles with samples were cooled and weighed. The percentage of moisture in the samples was calculated as follows:

$$
\text { Moisture, } \%=[(\mathrm{A}-\mathrm{B}) / \mathrm{A}] \times 100
$$

Where, $\mathrm{A}=$ grams of air-dried sample used, and

$$
\mathrm{B}=\text { grams of sample after drying at } 105^{\circ} \mathrm{C}
$$


The VM content was measured as the mass lost at $950^{\circ} \mathrm{C}$. The crucibles containing the samples used for the moisture content determination were covered with lids and placed in the muffle furnace at $950^{\circ} \mathrm{C}$ for six minutes. After the crucibles with samples cooled, the weight was recorded. The percentage of VM content in the samples was calculated as follows:

$$
\text { Volatile matter, } \%=[(\mathrm{B}-\mathrm{C}) / \mathrm{B}] \times 100
$$

Where, $\mathrm{B}=$ grams of sample after drying at $105^{\circ} \mathrm{C}$

$\mathrm{C}=$ grams of sample after drying at $950^{\circ} \mathrm{C}$

Ash content was measured as the mass remaining after heating at $750^{\circ} \mathrm{C}$. The crucibles containing samples dried at $105^{\circ} \mathrm{C}$ were placed uncovered in the muffle furnace at $750^{\circ} \mathrm{C}$ for 6 hours. Weight of the cooled crucibles with samples were determined. The percentage of ash content in the samples was calculated as follows:

$$
\text { Ash content, } \%=(\mathrm{D} / \mathrm{B}) \times 100
$$

Where, $\mathrm{B}=$ grams of sample after drying at $105^{\circ} \mathrm{C}$

$\mathrm{D}=$ grams of residue

Fixed C, which corresponds to the stable carbon fraction of the sample was determined as:

$$
\text { Fixed C, }(\%)=[1-(\text { ash content }+\mathrm{VM} \text { content })] \times 100
$$

The $\mathrm{pH}$ of the biochar samples was measured in a 1:20 (w/v) biochar/deionized water mixture using a Denver instrument $\mathrm{pH}$ meter. The cation exchange capacity (CEC) was analyzed by a modified $\mathrm{NH}_{4}{ }^{+}$acetate compulsory displacement method (Gaskin et al., 2008). An amount of $0.2 \mathrm{~g}$ biochar was leached with $20 \mathrm{ml}$ deionized (DI) water for five times, followed by further leaching with $20 \mathrm{ml}$ of $1 \mathrm{M}$ sodium $\left(\mathrm{Na}^{+}\right)$acetate $(\mathrm{pH} 7)$ solution 
for five times. The biochar samples were then washed with $20 \mathrm{ml}$ of ethanol for five times to remove any excess sodium. Finally, the sodium on the exchangeable sites of the biochar was displaced by $20 \mathrm{ml}$ of $1 \mathrm{M}$ ammonium $\left(\mathrm{NH}_{4}^{+}\right)$acetate $(\mathrm{pH}$ 7) solution for five times and the leachates were stored at $4^{\circ} \mathrm{C}$ prior to analysis. The $\mathrm{CEC}$ of the biochars were calculated from the sodium displaced by ammonium using a Perkin Elmer inductively coupled plasma- optical emission spectroscopy (ICP-OES) instrument. Biochar samples were sent to Galbraith Laboratories, Inc., Tennessee, USA for elemental (carbon, hydrogen, nitrogen, oxygen, and sulfur content) analysis. The Micromeritics Tristar II surface area and porosity analyzer (Micromeritics, Georgia, USA) at the Department of Mechanical and Materials Engineering, FIU, was used to measure the Brunauer-EmmettTeller (BET) surface area, pore volume, and average pore size of the biochars. All samples were prepared in triplicates.

\subsubsection{Statistical analysis}

Statistical analysis was performed using a statistical analysis system (SAS 9.4 and JMP pro 14). Results were expressed as means and standard errors. Any differences between the mean values at $p<0.05$ were considered statistically significant.

\subsection{Results and Discussion}

Detailed information on biochar yield, proximate analysis, and physiochemical properties are presented in Tables 2.1 and 2.2 which show considerable variation between the twelve different biochars used in this study. Yield (\%), VM (\%), and moisture (\%) content of the biochars produced from pyrolysis of the six different feedstocks (Australian pine, AP; Brazilian pepper, BP; Coconut husk, $\mathrm{CH}$; Cypress, Cy; Loblolly pine, L; and Pecan shell, $\mathrm{P})$ decreased significantly $(p<0.05)$ as the temperature increased from $350^{\circ} \mathrm{C}$ 
to $500^{\circ} \mathrm{C}$ (Table 2.1 ). The average yield reduction (about $18 \%$ ) of the biochars with increasing pyrolysis temperature was owing to the dehydration of hydroxyl $\left(\mathrm{OH}^{-}\right)$groups and thermal degradation of ligno-cellulose structures (Antal and Gronli, 2003; Novak et al., 2009). Average VM and moisture content were reduced by $18 \%$ and $50 \%$, respectively, with increasing pyrolysis temperature. Previous studies reported that during the pyrolysis process the major component contributing higher char yield is the lignin contents, whereas, hemicelluloses and cellulose contents are mainly responsible for higher VM content of the biochar (Sugumaran and Seshadri, 2009; Maia et al., 2011; Sugumaran et al., 2012). Higher pyrolysis temperature can increase the degree of aromatization (Chen et al., 2016) and cause higher loss of gas products, tar oil, and low molecular weight hydrocarbons [such as methane $\left(\mathrm{CH}_{4}\right)$, ethane $\left(\mathrm{C}_{2} \mathrm{H}_{6}\right)$, and propane $\left.\left(\mathrm{C}_{3} \mathrm{H}_{8}\right)\right]$ (Domingues et al., 2017) which potentially reduce the VM contents of the biochars produced. The reduction in VM was an indication of greater pore formation on the biochars at higher pyrolysis temperatures (Lehman and Joseph, 2009). Pores produced in high temperature biochars serve as a potential habitat for microorganisms (Brewer et al., 2009; Downie et al., 2009) and offer higher sorption ability of organic compounds in soil (Chen et al., 2008; Cabrera et al., 2011). The presence of VM can be either favorable (Elad et al., 2010; Graber et al., 2010) or harmful (Jones et al., 2011) to different microbial communities in soil depending on the composition. The VM contents can act as a source of the substrate along with carbon and energy for soil microorganisms which tend to improve soil fertility (Khodadad et al., 2011; Jindo et al., 2014). 
Table 2. 1 Yield, proximate analysis and selected physicochemical properties of the twelve different biochars made at two production temperatures.

\begin{tabular}{|c|c|c|c|c|c|c|c|c|c|c|c|c|}
\hline \multirow[b]{2}{*}{ Sample } & \multirow[b]{2}{*}{ Feedstock } & \multirow[b]{2}{*}{$\begin{array}{c}\text { Temp. }{ }^{\dagger} \\
\left({ }^{\circ} \mathrm{C}\right)\end{array}$} & \multirow[b]{2}{*}{$\begin{array}{l}\text { Biochar } \\
\text { Yield } \\
(\%)\end{array}$} & \multicolumn{4}{|c|}{ Proximate Analysis } & \multirow[b]{2}{*}{$\mathrm{pH}$} & \multirow[b]{2}{*}{$\begin{array}{l}\mathrm{CEC}^{\ddagger} \\
\left(\mathrm{cmol} \mathrm{kg}^{-1}\right)\end{array}$} & \multirow[b]{2}{*}{$\begin{array}{c}\mathrm{SSA}^{\S} \\
\left(\mathrm{m}^{2} \mathrm{~g}^{-1}\right)\end{array}$} & \multirow[b]{2}{*}{$\begin{array}{c}\mathrm{TPV}^{\top} \\
\left(\mathrm{cm}^{3}\right. \\
\left.\mathrm{g}^{-1}\right)\end{array}$} & \multirow[b]{2}{*}{$\begin{array}{c}\text { Average } \\
\text { pore size } \\
(\mathrm{nm})\end{array}$} \\
\hline & & & & $\begin{array}{c}\text { Volatile } \\
\text { Matter } \\
\text { Content } \\
(\%)\end{array}$ & $\begin{array}{l}\text { Ash } \\
\text { Content } \\
(\%)\end{array}$ & $\begin{array}{l}\text { Moisture } \\
\text { Content } \\
(\%)\end{array}$ & $\begin{array}{c}\text { Fixed C } \\
(\%)\end{array}$ & & & & & \\
\hline AP350 & Australian pine & 350 & 41.00 & $79.24 \pm 2.39^{\mathrm{AB}}$ & $5.32 \pm 1.11^{\mathrm{B}}$ & $5.85 \pm 0.09^{\mathrm{ABCD}}$ & $15.44 \pm 3.50^{\mathrm{B}}$ & $8.58 \pm 0.03^{\mathrm{C}}$ & $16.31 \pm 5.50^{\mathrm{A}}$ & $0.98 \pm 0.07$ & 0.003 & 12.46 \\
\hline AP500 & $\begin{array}{l}\text { (Casaurina } \\
\text { equisetifolia) }\end{array}$ & 500 & 33.10 & $61.35 \pm 5.67^{\mathrm{ABC}}$ & $10.19 \pm 0.91^{\mathrm{A}}$ & $2.81 \pm 0.19^{\mathrm{DE}}$ & $28.46 \pm 6.59^{\mathrm{AB}}$ & $9.37 \pm 0.03^{\mathrm{B}}$ & $8.19 \pm 1.43^{\mathrm{A}}$ & $2.59 \pm 0.29$ & 0.006 & 9.40 \\
\hline BP350 & $\begin{array}{l}\text { Brazilian } \\
\text { pepper }\end{array}$ & 350 & 41.60 & $66.47 \pm 9.32^{\mathrm{ABC}}$ & $2.06 \pm 1.00^{\mathrm{CD}}$ & $4.40 \pm 0.47^{\mathrm{BCDE}}$ & $31.48 \pm 8.32^{\mathrm{AB}}$ & $7.72 \pm 0.08^{\mathrm{DE}}$ & $8.47 \pm 2.51^{\mathrm{A}}$ & $0.57 \pm 0.08$ & 0.002 & 12.26 \\
\hline BP500 & $\begin{array}{l}\text { (Schinus } \\
\text { terebinthifolius) }\end{array}$ & 500 & 33.00 & $55.80 \pm 3.79^{\mathrm{BC}}$ & $4.02 \pm 0.02^{\mathrm{BC}}$ & $1.96 \pm 0.98^{\mathrm{E}}$ & $40.18 \pm 3.82^{\mathrm{AB}}$ & $9.65 \pm 0.02^{\mathrm{AB}}$ & $7.92 \pm 2.30^{\mathrm{A}}$ & $2.29 \pm 0.26$ & 0.008 & 14.60 \\
\hline $\mathrm{CH} 350$ & Coconut husk & 350 & 47.20 & $85.05 \pm 2.45^{\mathrm{A}}$ & $3.74 \pm 0.48^{\mathrm{BC}}$ & $8.81 \pm 0.81^{\mathrm{A}}$ & $11.21 \pm 1.97^{\mathrm{B}}$ & $9.40 \pm 0.09^{\mathrm{B}}$ & $16.32 \pm 3.46^{\mathrm{A}}$ & $0.89 \pm 0.15$ & 0.003 & 13.31 \\
\hline CH500 & $\begin{array}{l}\text { (Cocos } \\
\text { nusifera) }\end{array}$ & 500 & 40.30 & $79.37 \pm 1.48^{\mathrm{AB}}$ & $8.88 \pm 0.38^{\mathrm{A}}$ & $4.96 \pm 0.92^{\mathrm{BCDE}}$ & $11.75 \pm 1.85^{\mathrm{B}}$ & $9.89 \pm 0.10^{\mathrm{A}}$ & $12.04 \pm 1.07^{\mathrm{A}}$ & $1.94 \pm 0.22$ & 0.004 & 7.99 \\
\hline Су 350 & Cypress & 350 & 37.70 & $72.75 \pm 1.17^{\mathrm{ABC}}$ & $0.55 \pm 0.05^{\mathrm{D}}$ & $6.51 \pm 0.57^{\mathrm{ABC}}$ & $26.71 \pm 1.22^{\mathrm{AB}}$ & $7.11 \pm 0.01^{\mathrm{G}}$ & $10.55 \pm 0.20^{\mathrm{A}}$ & $0.41 \pm 0.07$ & 0.001 & 10.01 \\
\hline Сy500 & $\begin{array}{l}\text { (Taxodium } \\
\text { distichum) }\end{array}$ & 500 & 30.00 & $62.66 \pm 7.56^{\mathrm{ABC}}$ & $1.59 \pm 0.11^{\mathrm{CD}}$ & $2.45 \pm 0.52^{\mathrm{E}}$ & $36.76 \pm 7.67^{\mathrm{AB}}$ & $7.67 \pm 0.01^{\mathrm{DE}}$ & $9.18 \pm 2.46^{\mathrm{A}}$ & $4.18 \pm 0.47$ & 0.002 & 2.39 \\
\hline L350 & Loblolly pine & 350 & 39.60 & $71.31 \pm 6.00^{\mathrm{ABC}}$ & $1.70 \pm 0.10^{\mathrm{CD}}$ & $3.46 \pm 0.46^{\mathrm{CDE}}$ & $26.98 \pm 6.11^{\mathrm{AB}}$ & $7.63 \pm 0.05^{\mathrm{EF}}$ & $8.51 \pm 1.84^{\mathrm{A}}$ & $0.30 \pm 0.06$ & 0.001 & 12.81 \\
\hline L500 & (Pinus taeda) & 500 & 32.20 & $48.59 \pm 7.53^{\mathrm{C}}$ & $3.20 \pm 0.19^{\mathrm{BCD}}$ & $2.36 \pm 0.56^{\mathrm{E}}$ & $48.21 \pm 7.73^{\mathrm{A}}$ & $7.84 \pm 0.01^{\mathrm{DE}}$ & $7.93 \pm 4.34^{\mathrm{A}}$ & $5.21 \pm 0.56$ & 0.004 & 3.13 \\
\hline P350 & Pecan shell & 350 & 46.80 & $68.04 \pm 4.12^{\mathrm{ABC}}$ & $2.18 \pm 0.12^{\mathrm{CD}}$ & $6.83 \pm 0.09^{\mathrm{AB}}$ & $29.78 \pm 4.24^{\mathrm{AB}}$ & $7.36 \pm 0.02^{\mathrm{FG}}$ & $6.14 \pm 1.18^{\mathrm{A}}$ & $0.36 \pm 0.05$ & 0.001 & 14.56 \\
\hline P500 & illinoinensis) & 500 & 39.20 & $56.33 \pm 1.12^{\mathrm{ABC}}$ & $3.82 \pm 0.29^{\mathrm{BC}}$ & $3.50 \pm 0.50^{\mathrm{CDE}}$ & $39.85 \pm 1.42^{\mathrm{AB}}$ & $7.94 \pm 0.03^{\mathrm{D}}$ & $4.66 \pm 1.41^{\mathrm{A}}$ & $2.14 \pm 0.34$ & 0.002 & 4.41 \\
\hline
\end{tabular}

Sample abbreviations are the same as in Figure 2.1.

Temp. $=$ Production temperature

${ }^{*} \mathrm{CEC}=$ Cation exchange capacity

${ }^{\S} \mathrm{SSA}=$ Specific surface area

"TPV $=$ Total pore volume

Numbers are mean \pm standard error.

Means within a column followed by the same letter are not significantly different at $p<0.05$. 
Table 2. 2 Elemental composition and atomic ratio of the twelve different biochars.

\begin{tabular}{|c|c|c|c|c|c|c|c|c|}
\hline \multirow[b]{2}{*}{ Sample } & \multirow[b]{2}{*}{$\begin{array}{c}\text { Carbon } \\
(\%)\end{array}$} & \multirow[b]{2}{*}{$\begin{array}{l}\text { Hydrogen } \\
(\%)\end{array}$} & \multirow[b]{2}{*}{$\begin{array}{l}\text { Nitrogen } \\
\quad(\%)\end{array}$} & \multirow[b]{2}{*}{$\begin{array}{l}\text { Oxygen } \\
(\%)\end{array}$} & \multirow[b]{2}{*}{$\begin{array}{l}\text { Sulfur } \\
(\%)\end{array}$} & \multicolumn{3}{|c|}{$\begin{array}{l}\text { Atomic ratio of the elements } \\
\text { in biochar }\end{array}$} \\
\hline & & & & & & $\mathrm{H} / \mathrm{C}^{\ddagger}$ & $\mathrm{O} / \mathrm{C}^{\S}$ & $(\mathrm{N}+\mathrm{O}) / \mathrm{C}^{\mathbb{f}}$ \\
\hline AP350 & 64.93 & 4.00 & 0.94 & 21.80 & 0.07 & 0.06 & 0.34 & 0.35 \\
\hline AP500 & 66.65 & 3.07 & 1.10 & 15.66 & 0.04 & 0.05 & 0.23 & 0.25 \\
\hline BP350 & 67.54 & 3.97 & 0.5 & 20.89 & 0.11 & 0.06 & 0.31 & 0.32 \\
\hline BP500 & 77.37 & 3.04 & 0.51 & 11.76 & 0.13 & 0.04 & 0.15 & 0.16 \\
\hline CH350 & 66.69 & 4.02 & 0.51 & 22.81 & 0.03 & 0.06 & 0.34 & 0.35 \\
\hline CH500 & 67.00 & 3.01 & 0.69 & 18.29 & 0.03 & 0.04 & 0.27 & 0.28 \\
\hline Су350 & 76.10 & 4.39 & 0.5 & 17.31 & 0.01 & 0.06 & 0.23 & 0.23 \\
\hline Су500 & 83.59 & 3.39 & 0.5 & 11.11 & 0.04 & 0.04 & 0.13 & 0.14 \\
\hline $\mathrm{L} 350$ & 67.71 & 4.25 & 0.5 & 17.13 & 0.09 & 0.06 & 0.25 & 0.26 \\
\hline L500 & 79.47 & 3.52 & 0.5 & 12.97 & 0.08 & 0.04 & 0.16 & 0.17 \\
\hline P350 & 68.45 & 3.59 & 0.5 & 22.85 & 0.04 & 0.05 & 0.33 & 0.34 \\
\hline P500 & 78.96 & 3.21 & 0.5 & 12.10 & 0.03 & 0.04 & 0.15 & 0.16 \\
\hline
\end{tabular}

Sample abbreviations are the same as in Figure 2.1.

${ }^{\sharp} \mathrm{H} / \mathrm{C}=$ Ratio of hydrogen and carbon

$\S_{\mathrm{O}} / \mathrm{C}=$ Ratio of oxygen and carbon

${ }^{\mathrm{I}}(\mathrm{N}+\mathrm{O}) / \mathrm{C}=$ Ratio of nitrogen and oxygen with carbon

Ash content of the biochars significantly $(p<0.05)$ increased with increasing pyrolysis temperature, likely because the ash mainly remains in the solid fraction and increasing temperature increase the concentrations of minerals and combusted organic residues (Cao and Harris, 2010). Increase of more than twice in ash content of the biochars was observed as the pyrolysis temperature increased from $350^{\circ} \mathrm{C}$ to $500^{\circ} \mathrm{C}$ (Table 2.1). Ash is an important factor that influences the sorption behavior of hydrophobic organic compounds (HOCs) which can block surface sorption sites in biochar or make it difficult to access because of their interactions with inorganic moieties (Zhang et al., 2013; Deng et al., 2014).

Similar to ash content, an increase in pyrolysis temperature also significantly increased the fixed $\mathrm{C}$ content of the biochars. An increase in pyrolysis temperature from 
$350^{\circ} \mathrm{C}$ to $500^{\circ} \mathrm{C}$ had resulted in about $70 \%$ increase (significant at $p<0.05$ ) in fixed $\mathrm{C}$ content of the biochars (Table 2.1) mainly because higher pyrolysis temperature can reduce overall biochar mass (Ronsee et al., 2013).

An average $10 \%$ increase of biochar $\mathrm{pH}$ with increased pyrolysis temperature possibly resulted from the gradual removal of acid functional groups [such as carboxylic $(-\mathrm{COOH})$, phenolic $(-\mathrm{C} 6 \mathrm{H} 5)$, and carbonyl $(-\mathrm{C}=\mathrm{O})$ group] from biochar surface and relative increase of ash contents. Biochars with $\mathrm{pH}$ in the alkaline range have the potential for neutralizing or increasing the $\mathrm{pH}$ of acidic soils (Sohi et al., 2010; Deng et al., 2014) which in turn provides a more favorable habitat for plants and microbes (Gaskin et al., 2008; Spokas et al., 2012). A study conducted by Novak et al. (2009) in South Carolina, USA showed that an application of $2 \%$ pecan shell derived biochar (produced at $700^{\circ} \mathrm{C}$ ) significantly increased the soil $\mathrm{pH}$ from 4.8 to 6.3 . An increase in soil $\mathrm{pH}$ can also facilitate enhanced germination (Cornelissen et al., 2018) and is often considered as a positive predictor for biochar impact on plant growth (Solaiman et al., 2012).

Cation exchange capacity (CEC) of the biochars decreased with increased pyrolysis temperature, however, no significant difference was observed (Table 2.1). As discussed earlier, increase in temperature resulted in the loss of oxygen-containing groups, such as, hydroxyl $\left(\mathrm{OH}^{-}\right)$, carboxylic $(-\mathrm{COOH})$, and carbonyl $(-\mathrm{C}=\mathrm{O})$ groups which resulted in the decrease of the biochar CEC (Song and Gao, 2012; Zornoza et al., 2016; Domingues et al., 2017; Batista et al., 2018). The CEC was also found to be associated with $\mathrm{O} / \mathrm{C}$ ratios (Table 2.2), where a high $\mathrm{O} / \mathrm{C}$ ratio produced a high $\mathrm{CEC}$ value. In a recent study, Zhao et al. (2017) found a positive relationship between the O/C ratio and CEC of the biochars (Apple tree; Malus pumila) produced at a temperature range of $300^{\circ} \mathrm{C}$ to $600^{\circ} \mathrm{C}$. In another study 
conducted in Brazil, Batista et al (2018) used Cocos nusifera (coconut shell), Citrus sinensis (orange peel), Elaeis guineensis (palm oil bunch), Saccharum officinarum (sugarcane bagasse), and Eichhornia crassipes (water hyacinth) feedstocks to make biochars at $350^{\circ} \mathrm{C}$ and found that low $\mathrm{O} / \mathrm{C}$ ratios are associated with low $\mathrm{CEC}$ of the biochars. The CEC of biochars have the potential to retain nutrients in the soil (Domingues et al., 2017). High CEC biochars can also be beneficial for the remediation of cationic trace elements found in contaminated soil (Cao et al., 2009; Houben et al., 2013; Cayuela et al., 2014).

Specific surface area (SSA) and total pore volume (TPV) of the biochars were numerically increased (but not significant at $p<0.05$ ) with higher temperatures. However, the average pore size of different biochars decreased with increased charring temperature with an exception for biochars made from BP where the average pore size increased at $500^{\circ} \mathrm{C}$. The decomposition of cellulose and hemicelluloses, removal of pore blocking substances, destruction of aliphatic alkyls and ester groups, exposure of the aromatic lignin core, thermal cracking, and formation of vesicular bundles or channel structures have been considered responsible for the high SSA and TPV in biochar with increasing pyrolysis temperature (Chen and Chen 2009; Ahmad et al. 2012; Li et al. 2013; Rafiq et al. 2016; Zhao et al. 2017). The condensation reaction of organic compounds causes the decrease in biochar pore size with increasing pyrolysis temperature (Giudicianni et al., 2013). Biochars having high SSA and TPV are considered as potential agents for the sorption of organic compounds in the soil (Chen et al., 2008; Cabrera et al., 2011).

The biochars had both carbonized (such as volatile matter, carbon content, $\mathrm{H} / \mathrm{C}$, $\mathrm{O} / \mathrm{C}$ ratio) and non-carbonized (such as ash content) fractions (Tables 2.1 and 2.2), 
indicating that the biochars were heterogeneous (Chen et al. 2008; Cao et al. 2009). It was observed that $\mathrm{C}(\%)$ content of the biochars increased while the $\mathrm{H}(\%)$ and $\mathrm{O}(\%)$ contents decreased as the pyrolysis temperature increased from $350^{\circ} \mathrm{C}$ to $500^{\circ} \mathrm{C}$ (Table 2.2). The increase in $\mathrm{C}$ content was the result of the high carbonization and high degree of carbon clustering in the aromatic structures as a result of increase in temperature (Novak et al., 2009; Keiluweit et al., 2010). The reduction in $\mathrm{H}$ content was relatively small because of an increase in temperature and almost negligible for the different feedstocks. All the biochars contained a relatively small amount of $\mathrm{N}(\%)$ which ranged from $0.5 \%$ to $1.1 \%$ and the $\mathrm{N}$ content remained relatively stable with very little change regardless of temperature and feedstock. The elemental composition of the biochars was used to calculate the atomic ratio for each biochar (Table 2.2). The $\mathrm{H} / \mathrm{C}, \mathrm{O} / \mathrm{C}$, and $(\mathrm{N}+\mathrm{O}) / \mathrm{C}$ ratios for all biochars decreased as the pyrolysis temperature increased. The elemental ratio of $\mathrm{H} / \mathrm{C}$ is used to evaluate the degree of carbonization and aromaticity of the biochar and is linked to the long-term stability in the environment (Schmidt and Noack, 2000). The low values represent a high degree of carbonization and aromaticity (Chun et al., 2004; Chen et al., 2005). A decrease in $\mathrm{O} / \mathrm{C}$ and $(\mathrm{N}+\mathrm{O}) / \mathrm{C}$ ratios indicate the reduction in biochar polarity (Chen et al., 2005). An increase in aromaticity and a decrease in polarity reflect higher sorption capacity of the biochars (Chen et al., 2005). Hydrophobic carbon can provide more sorption domains for HOCs, and aromaticity and pore-filling are positively correlated with aromatic carbon contents (Teixidó et al., 2011; Yang et al., 2011; Deng et al., 2014).

Among the different feedstocks, coconut husk $(\mathrm{CH})$ biochars had the highest yield (1-10\%), VM content (12-21\%), moisture content (3.5-9.5\%), pH (8-30\%), and CEC (16- 
$163 \%)$ than the biochars made from the remaining five feedstocks. Comparing the twelve biochars, it was found that $\mathrm{CH} 350$ biochar had the highest (significant at $p<0.05$ ) VM (85\%) and moisture content (8.81\%) (Table 2.1). Higher biochar yield from coconut husk, which can be considered as an agricultural residue (or waste), makes it an excellent feedstock for manufacturing abundant biochar in a cost-effective way. The high $\mathrm{pH}(9.40$ to 9.89) content of $\mathrm{CH}$ biochars makes it an useful liming material in acidic soils and the high CEC (12.02 to $\left.16.32 \mathrm{cmol} \mathrm{kg}^{-1}\right)$ can be effective in removing inorganic and organic contaminants from the soil. High pore volume and pore size of biochars made from Brazilian pepper (invasive in South Florida, USA) would also be very useful for the sorption of organic compounds and an excellent habitat for soil microorganisms.

The principal component analysis (PCA) biplot of biochar properties is presented in Figure 2.2. The PCA biplot is a combination of the PCA score and the loading plot. Principal component 1 (PC1) and principal component 2 (PC2) explains $48 \%$ and $21 \%$ of the total variance for the results. For $\mathrm{PC} 1$, the main contributing parameters were $\mathrm{O}$ content, $\mathrm{O} / \mathrm{C}$, and $(\mathrm{N}+\mathrm{O}) / \mathrm{C}$ ratios, whereas, $\mathrm{pH}$, ash content, $\mathrm{TPV}, \mathrm{H}$ content, and $\mathrm{N}$ content were the main contributing parameters for PC2. The angle between vector ash content, N content, and $\mathrm{pH}$ was very small which indicates the existence of a strong positive correlation between these variables. Similarly, $\mathrm{O}$ content, $\mathrm{O} / \mathrm{C},(\mathrm{N}+\mathrm{O}) / \mathrm{C}, \mathrm{VM}$ content, SSA, and average pore size had a strong positive correlation. Vectors positioned about 90 degrees to each other were not correlated. Therefore, ash, $\mathrm{pH}, \mathrm{N}$ content had no relation with $\mathrm{VM}$ content, $\mathrm{O}$ content, $\mathrm{O} / \mathrm{C},(\mathrm{N}+\mathrm{O}) / \mathrm{C}$, and average pore size. Vectors that were situated at 180 degrees angle were negatively correlated. Therefore, SSA had a strong 
negative correlation with $\mathrm{O}$ content, $\mathrm{O} / \mathrm{C},(\mathrm{N}+\mathrm{O}) / \mathrm{C}, \mathrm{VM}$ content, and average pore size. Similarly, TPV and H content were negatively correlated.

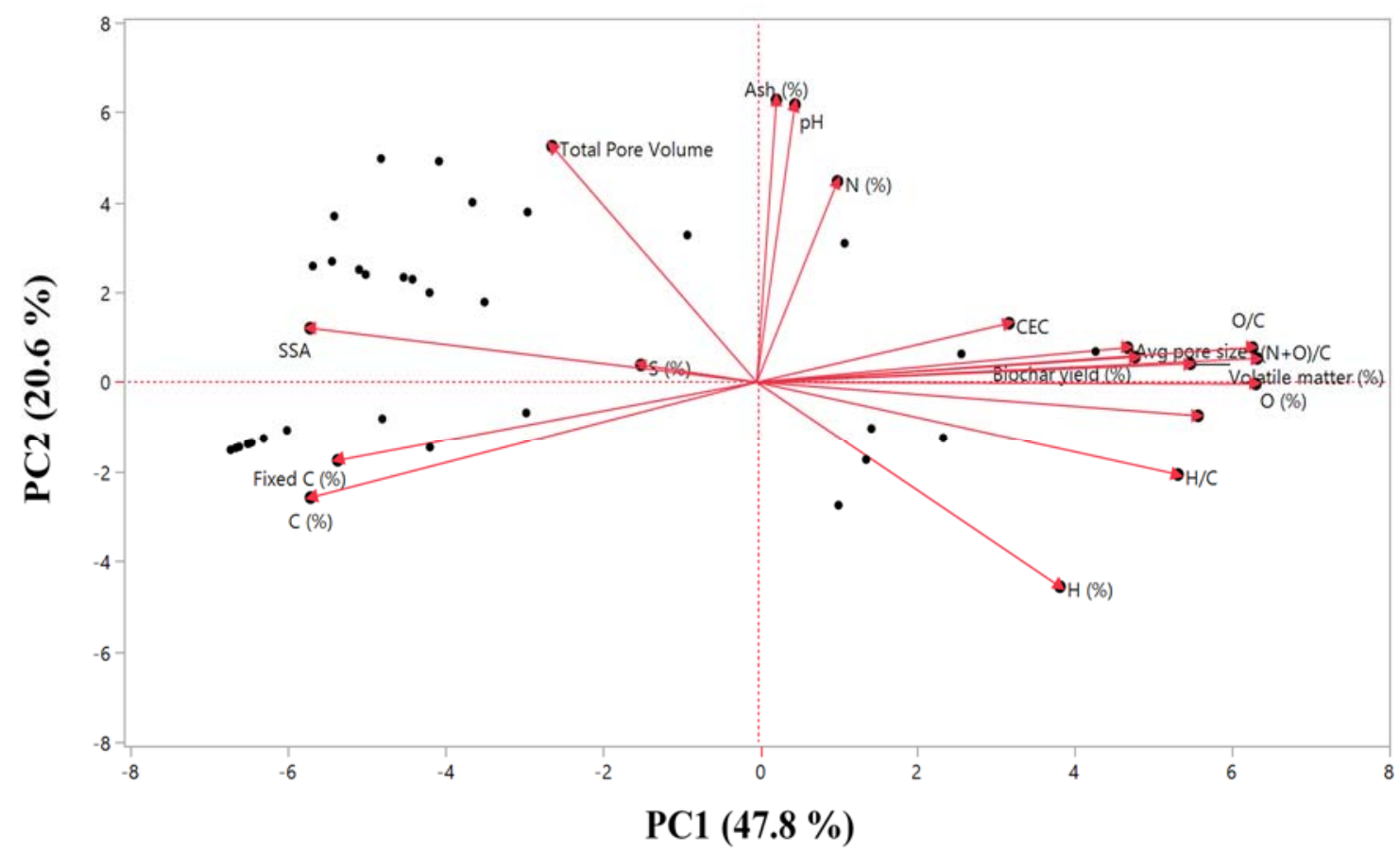

Figure 2. 2 Principal component analysis of the parameters measured for the characterization of biochars. $\mathrm{PC} 1$ explains $48 \%$ of the variance which is mainly a combination of $\mathrm{O}$ content $(\%), \mathrm{O} / \mathrm{C}$ and $(\mathrm{N}+\mathrm{O}) / \mathrm{C}$ ratios. PC2 in mainly a combination of $\mathrm{pH}$ and ash content (\%) and explains $21 \%$ of the variance.

The parameters from the PCA analysis was also used for hierarchical cluster analysis of the biochars (Figure 2.3). Biochars made at $500^{\circ} \mathrm{C}$ were different from the ones made at $350^{\circ} \mathrm{C}$. Among the biochars made at $500^{\circ} \mathrm{C}$, AP500 and $\mathrm{CH} 500$ were clustered together reflecting maximum similarity than the rest. For biochars made at $350^{\circ} \mathrm{C}, \mathrm{Cy} 350$ and L350 showed more similarity than the remaining biochars. The hierarchical clustering is helpful in further explaining similar effects from biochar applications. 


\section{Cluster Dendrogram}

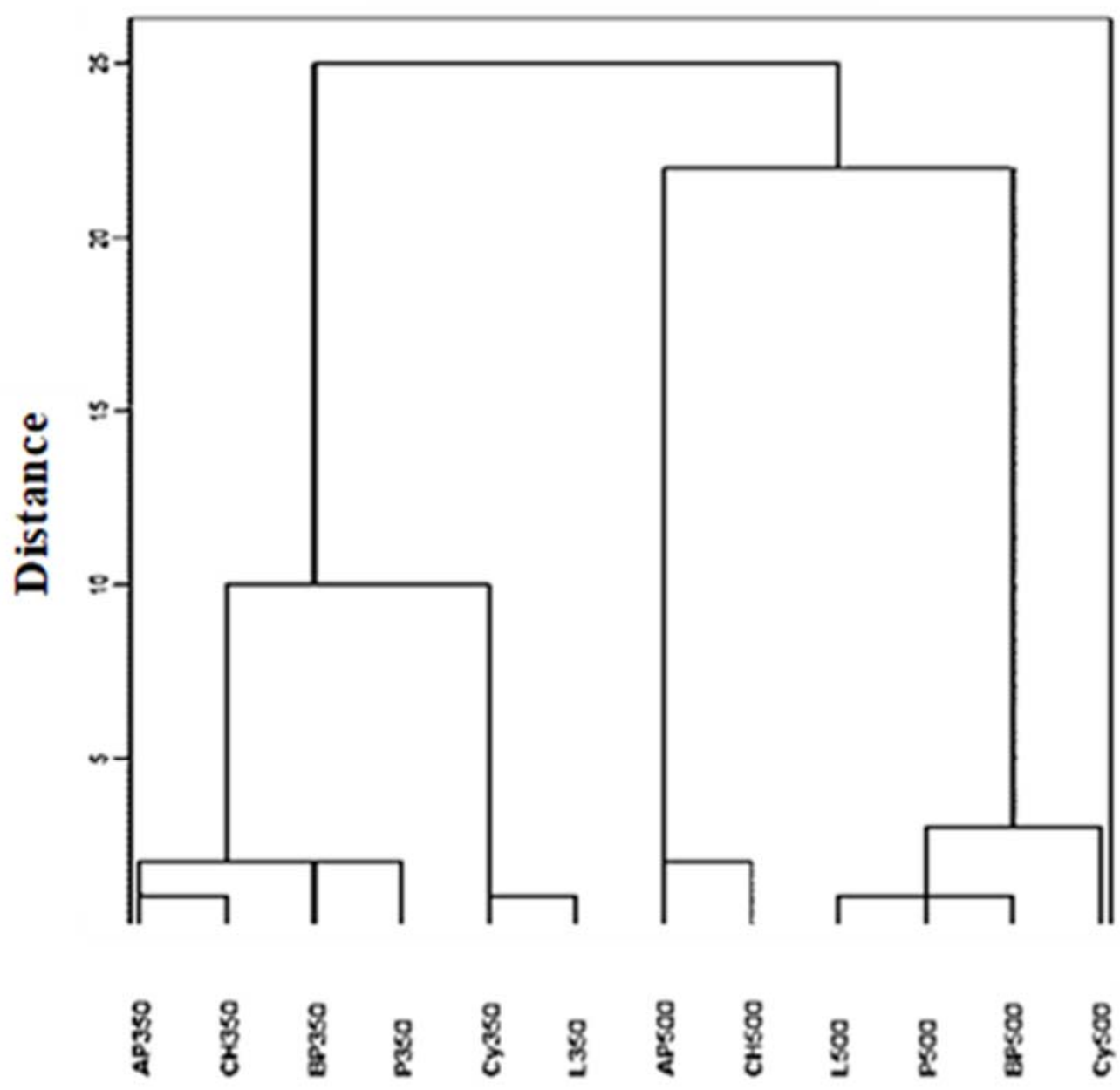

Biochar

Figure 2. 3 Hierarchical cluster analysis of the biochars based on the parameters from principal component analysis. Biochars with similar characteristics are clustered together. Sample abbreviations are the same as in Figure 2.1.

\subsection{Conclusion}

The data presented show that the pyrolysis temperature and the type of feedstock strongly influenced the physicochemical properties of the biochars. Higher pyrolysis temperatures resulted in biochars with higher ash content, $\mathrm{pH}$, specific surface area and pore volume. The increase in pyrolysis temperature decreased the moisture and volatile 
matter content, cation exchange capacity and the average pore size of the biochars. Variation in the physicochemical properties of the biochars greatly influence their potential in improving the environment as a soil conditioner and amendment including its role in reducing pollution. It is possible to produce biochars with distinct characteristics aimed for specific purposes. Therefore, it is important to characterize biochars prior to its application to achieve satisfactory outcomes. 
CHAPTER 3: EFFECT OF DIFFERENT BIOCHARS ON THE ADSORPTION AND DESORPTION OF ATRAZINE IN SOIL

\section{Abstract}

Biochar, produced from pyrolyzed biomass, has increasingly been considered as a cost-effective agent to reduce the loss of organic contaminants from soil profile through its high sorption potentiality. Application of biochars in agricultural soil is expected to reduce groundwater contamination of atrazine, a widely used herbicide in the U.S., and therefore, sustain environmental quality and reduce human health issues caused by atrazine. The present study was conducted to investigate the comparative ability of twelve different biochars made from six feedstocks at two production temperatures to remove and retain atrazine in an organic rich soil. The biochars were categorized by feedstock type and production temperatures. Soils were amended with $2 \%(\mathrm{w} / \mathrm{w})$ of the different biochars. Freundlich isotherms were used to explain the adsorption and desorption behaviors of atrazine in soil. The biochar amendments significantly affected the adsorption of atrazine compared to the unamended soil. It was found that coconut husk produced the most effective biochars (CH350 and $\mathrm{CH} 500)$, which adsorb 8-12\% more atrazine than soils without biochar (unamended). In Particular, among all 12 biochars, $\mathrm{CH} 350$ performed the best $\left(\mathrm{K}_{\mathrm{d} \text { ads }}=13.80, \mathrm{~K}_{\mathrm{OC}}=153.63, \mathrm{~K}_{\mathrm{d} \text { des }}=16.98\right)$ and had significantly higher $(p<0.05)$ adsorption than unamended soil possibly resulting from the highest cation exchange capacity of $\mathrm{CH} 350\left(16.32 \mathrm{cmol} \mathrm{kg}^{-1}\right)$. Additionally, biochars made from plant species native to South Florida, USA (loblolly pine and pecan shell) had 7-10\% higher sorption of atrazine compared to the biochars produced from non-native invasive species (AP and BP) suggesting that biochars produced from native species perform better in the same 
agroclimatic regions where they grow. The overall $\mathrm{K}_{\mathrm{d} \text { des }}$ values for atrazine desorption were found to be greater than the $\mathrm{K}_{\mathrm{d} \text { ads }}$ for the adsorption indicating a considerable amount of the atrazine that was adsorbed by the biochar amended soils were retained following desorption.

\subsection{Introduction}

Atrazine (2-chloro-4-ethylamino-6-isopropylamino-1,3,5-trithemazine) is one of the most commonly used herbicides (triazine group) in the United States to control preand post-emergence broadleaf weeds (Stellaria media, Taraxacum officinale, Lespedeza cuneata, etc.) in agricultural production. Herbicide accounted for approximately $59 \%$ of the total pesticide used in the U.S. agricultural sector and about 64 to 74 million pounds of atrazine was used for agricultural purposes in the U.S. in 2012 (Atwood and Paisley-Jones, 2017). Atrazine application was reported to benefit about $\$ 2.9$ billion every year for corn production in the U.S. (Bridges, 2011). However, atrazine can remain in the soil for several days to months when applied (ATSRD, 2003), and often break down relatively quickly by soil microorganisms (such as Arthrobacter, Nocardioides) which as a result easily contaminate ground and surface water systems. In recent decades, atrazine and its metabolites, namely, desethyl-atrazine [DEA; 2-amino-4-chloro-6-(isopropylamino)-striazine], deisopropyl-atrazine [DIA; 2-amino-4 chloro-6-(ethylamino)-s-triazine], and hydroxyl-atrazine [HA; 2-hydroxy-4-(ethylamino)-6-(isopropylamino)-s-triazine] have been commonly detected in soil, drinking water aquifers, shallow groundwater, and in surface water (Barbash et al., 2001; Sun et al., 2010; Lima et al., 2011). This is an imperative area of concern, because atrazine has been recognized as an endocrine disruptor in humans (Lasserre et al., 2009), also having adverse effects on the immune and central 
nervous systems of other mammals and aquatic invertebrates (Hayes et al. 2002; 2006; 2010). Several studies have shown that the adverse health effects of atrazine include increased risk of intrauterine growth retardation, reduced semen quality, and spontaneous abortions in humans, as well as demasculinization and hermaphrodism in frogs (Arbuckle, 2001; Hayes, 2002; 2006; 2010). Therefore, a viable issue remains to control the availability of atrazine in soil solution and their fate and transport in natural water resources. Sorption, a common physiochemical process, is an effective solution for controlling the loss of hydrophobic organic compounds (HOCs) like atrazine in the environment. Biochar, a byproduct of thermal pyrolysis of carbon-rich biomass, is often used as a soil amendment in agricultural fields (Laird et al., 2009; Lehmann and Joseph, 2009; Yao et al., 2010) and has the potentiality to adsorb HOCs when applied and thus reduce their loss from the soil profile. Biochar is also an effective agent for accumulating soil organic $\mathrm{C}$ (SOC) and reducing greenhouse gas emissions from the field (Lehmann et al., 2006; Glaser et al., 2009; Spokas et al., 2009; McHenry, 2010; Fidel et al., 2019), influencing soil nutrient availability and crop production (Graber et al., 2010; Major et al., 2010), and soil microbial activity (Steiner et al., 2008). Adsorption is usually the first process that begins straightaway when pesticides are applied to the soil. One of the important factors influencing the effectiveness of biochars for pesticide retention is pyrolysis condition (Mesa and Spokas, 2011). Increasing pyrolysis temperature can increase surface area, $\mathrm{C}$ content, and aromaticity of the biochars along with the decrease in polarity, oxygen, and hydrogen contents (Ahmad et al., 2014, Chen and Chen, 2009, Chen et al., 2012). Consequently, the potential of biochars to sorb organic contaminants increase making it a unique adsorbent (Ahmad et al., 2014;_Khorram et. al, 2016). However, 
biochars produced at low pyrolysis temperatures $\left(250^{\circ} \mathrm{C}\right.$ to $\left.400^{\circ} \mathrm{C}\right)$ are characterized by high polarity and the amount of oxygen-containing functional groups on its surfaces, and consequently, an effective agent to remove inorganic/polar organic contaminants (Novak et. al., 2009; Ahmad et al., 2014; Gai et al., 2014). The surface functional groups, aromaticity, and negative surface charge of biochars can increase the sorption capacity via $\pi$ (lone pair electrons)- $\pi, \pi-\pi$ electron donor-acceptor (EDA) interactions, hydrogen bonding, hydrophobic binding, and electrostatic effects (Zhu et al., 2005; Sun et al., 2013; Fang et al., 2014; Xiao and Pignatello, 2015; Zhang et al., 2018). On the other hand, atrazine can function as a $\pi$ electron donor and both as an H-bond donor and acceptor (Sun et al., 2010, Deng et al., 2014, Ahmad et al., 2014). Thus, biochar can be an effective means to mitigate atrazine contamination in the environment. Study on the effect of different biochars made from feedstocks consisting of invasive plant species on atrazine sorption behavior has not been adequately investigated in the past. Therefore, the objective of the study was to investigate the effects of different biochars made from feedstocks that include invasive plant species along with native plants and agricultural residues on the adsorption and desorption of atrazine as an effective means for removing pesticides from the environment.

\subsection{Materials and Methods}

\subsubsection{Soil collection and analysis}

The soil (0-5 cm depth) was collected from the garden research plot $\left(25.7540^{\circ} \mathrm{N}\right.$, $80.3801^{\circ} \mathrm{W}$ ) at Florida International University (FIU). Soil samples were then air-dried, passed through a $2 \mathrm{~mm}$ sieve, and homogenized prior to use. Soil textural class was analyzed by the hydrometer method using a Fisher brand ATSM 152H soil hydrometer, 
the method quantitatively determines the proportions of sand, silt, and clay in soil as determined by their settling rates in an aqueous solution using a hydrometer. Soil $\mathrm{pH}$ was measured in a 1:2(w/v) soil/deionized water mixture using Denver instrument $\mathrm{pH}$ meter. The organic matter (OM) content was determined by the loss on ignition (LOI) method with a Fisher Scientific isotemp muffle furnace $\left(\right.$ at $550^{\circ} \mathrm{C}$ ) and the organic carbon (OC) content was calculated from the OM content. Total carbon (C) and nitrogen (N) content of the soil was measured using a Leco TruSpec $\mathrm{CN}$ analyzer. The selected physicochemical properties of the soil are presented in Table 3.1.

Table 3. 1 Physical and chemical properties of soil.

\begin{tabular}{ll}
\hline Parameters & Mean Values \\
\hline $\mathrm{pH}$ & $7.52 \pm 0.04$ \\
Carbon (\%) & $9.90 \pm 0.55$ \\
Nitrogen (\%) & $0.55 \pm 0.03$ \\
OM $(\%)^{\S}$ & $15.49 \pm 0.34$ \\
OC $(\%)^{\S}$ & $8.98 \pm 0.20$ \\
Sand $(\%)$ & 76.44 \\
Silt $(\%)$ & 21.65 \\
Clay $(\%)$ & 1.91 \\
\hline §OM = Organic matter content & \\
§OC = Organic carbon content & \\
Numbers are mean \pm standard error &
\end{tabular}

\subsubsection{Properties of chemicals used in this study}

Analytical grade of atrazine (2-chloro-4-ethylamino-6-isopropylamino-1,3,5trithemazine) with $\geq 98 \%$ purity was purchased from Cayman Chemical, Michigan, USA. It has an aqueous solubility of $33 \mathrm{mg} \mathrm{L}^{-1}$ at $22^{\circ} \mathrm{C}$ and $\mathrm{pH} 7$, a $\log \mathrm{P}_{\text {ow }}$ of 2.82 , and a $\mathrm{pKa}$ value of 1.7 (US-EPA, 2009; Mandal and Singh, 2017). A stock solution of $20 \mathrm{mg} \mathrm{L}^{-1}$ of 
atrazine was prepared in deionized water. High performance liquid chromatography (HPLC) grade methanol and water were purchased from Fisher Scientific, Pennsylvania, USA.

\subsubsection{Biochars used in the study}

The twelve biochars used in this study were produced from six feedstocks which included Australian pine (Casaurina equisetifolia), Brazilian pepper (Schinus terebinthifolius), coconut husk (Cocos nusifera), cypress (Taxodium distichum), loblolly pine (Pinus taeda), and pecan shell (Carya illinoinensis) pyrolyzed at temperatures $350^{\circ} \mathrm{C}$ and $500^{\circ} \mathrm{C}$ and denoted using feedstock and production temperature. The biochars have been characterized in chapter 2 of this study and selected physicochemical properties are listed in Tables 2.1 and 2.2.

\subsubsection{Adsorption and desorption experiments}

Adsorption of atrazine in soil with and without biochar amendments was measured using the batch equilibrium method (OCED, 2000). Ten $\mathrm{ml}$ of atrazine solutions with initial concentrations $\left(\mathrm{C}_{\mathrm{i}}, \mathrm{mg} \mathrm{L}^{-1}\right)$ ranging from 1 and $15 \mathrm{mg} \mathrm{L}^{-1}$ were added to centrifuge tubes containing $5.0 \mathrm{~g}$ of unamended soil and soils amended with $2 \%(\mathrm{w} / \mathrm{w})$ of the twelve biochars. Suspensions were shaken at $120 \mathrm{rpm}$ for 24 hours in a platform shaker at $20 \pm$ $2^{\circ} \mathrm{C}$ and centrifuged at $1500 \mathrm{rpm}$ for 20 minutes. The supernatants were filtered through a $0.45 \mu$ membrane using a syringe and stored at $4^{\circ} \mathrm{C}$ until analyzed. Desorption experiments were carried out after adsorption using the samples that had the maximum initial pesticide

concentration $\left(15 \mathrm{mg} \mathrm{L}^{-1}\right)$ by replacing half of the supernatant solution with deionized water. Equilibrium concentrations $\left(\mathrm{Ce}_{\mathrm{e}}, \mathrm{mg} \mathrm{L}^{-1}\right)$ of atrazine in the supernatants were analyzed using Agilent 1260 infinity high performance liquid chromatography (HPLC) 
instrument. The HPLC was equipped with a diode array detector and a Hypersil Green ENV C18 analytical column $(150 \times 4.6 \mathrm{~mm}, 3 \mu \mathrm{m})$. The mobile phase consisted of methanol/water $(50: 50, \mathrm{v} / \mathrm{v})$ mixture and the detector was set at $222 \pm 2 \mathrm{~nm}$. All samples were prepared in triplicates.

The amount of pesticide adsorbed was calculated as,

$\mathrm{C}_{\mathrm{s}}=\left(\mathrm{C}_{\mathrm{i}-\mathrm{C}}\right) \times \mathrm{V} / \mathrm{M}$

where, $\mathrm{V}=$ the volume of pesticide solution added $(\mathrm{ml})$

$\mathrm{M}=$ mass of adsorbent $(\mathrm{g})$

The amount of pesticide desorbed was calculated as the difference between the amount of pesticide determined in the solution after the desorption experiment and the amount of pesticide remaining from the adsorption experiment.

The percentage of pesticide adsorbed was calculated as, Adsorption $(\%)=\left[\left(\mathrm{C}_{\mathrm{i}}-\mathrm{C}_{\mathrm{e}}\right) / \mathrm{C}_{\mathrm{i}}\right] \times 100$

The percentage of pesticide desorbed was calculated as the ratio between the amount of pesticide desorbed and the amount adsorbed at equilibrium.

All the adsorption and desorption isotherms were fitted using the Freundlich equation, $\mathrm{C}_{\mathrm{s}}=\mathrm{K}_{\mathrm{f} .} \mathrm{Ce}^{1 / \mathrm{n}}$

where $\mathrm{C}_{\mathrm{s}}=$ amount of pesticide adsorbed $\left(\mathrm{mg} \mathrm{kg}^{-1}\right)$

$$
\mathrm{C}_{\mathrm{e}}=\text { equilibrium concentration of pesticide }\left(\mathrm{mg} \mathrm{L}^{-1}\right)
$$

$\mathrm{K}_{\mathrm{f}}$ and $1 / \mathrm{n}$ are empirical constants

$\mathrm{K}_{\mathrm{f}}$ is the sorption coefficient which indicates the sorption capacity of pesticide and $1 / \mathrm{n}$ is the slope isotherm which reflects the sorption intensity $(1 / \mathrm{n}=1$ represents a linear isotherm curve). The values of $\mathrm{K}_{\mathrm{f}}$ cannot be compared due to variation in $1 / \mathrm{n}$ values. Therefore, $\mathrm{K}_{\mathrm{d}}$ 
is estimated as the ratio between the amount of pesticide sorbed and the equilibrium concentration of $1 \mathrm{mg} \mathrm{L}^{-1}$. The estimated $\mathrm{K}_{d}$ values were further normalized to the organic carbon (OC) content of the soil to quantify Koc values,

$\mathrm{K}_{\mathrm{OC}}=\left(\mathrm{K}_{\mathrm{d}} / \% \mathrm{OC}\right) \times 100$

The Koc values are used to predict pesticide sorption because OC is usually considered to be the primary soil component responsible for the sorption of pesticides (Krutz et al., 2003). The hysteresis coefficient was determined as, $H=\left(1 / \mathrm{n}_{\text {des }}\right) /\left(1 / \mathrm{n}_{\text {ads }}\right)$, which gives information about the reversibility of adsorption.

\subsubsection{Statistical analysis}

Regression analysis was performed on adsorption and desorption isotherms. Statistical analysis was performed using a statistical analysis system (SAS 9.4 and JMP pro 14). Results were expressed as means and standard errors. Any differences between the mean values at $p<0.05$ were considered statistically significant.

\subsection{Results and Discussion}

\subsubsection{Physiochemical properties of the soil}

The soil used in the study had high OM content (>15\%) possibly because the soil was collected from garden plots which had compost incorporated and residues from previous cropping season (Table 3.1 ). The soil was slightly alkaline (7.52) with a loamy sand texture.

\subsubsection{Adsorption-desorption isotherms of Atrazine}

The Freundlich adsorption-desorption isotherm was used in the study to describe partitioning of atrazine between the biochar/soil solution and in the solid surface. The adsorption-desorption isotherms (Figures 3.1 and 3.2) helped understand the nature of 
interactions between atrazine and soils with and without biochar amendments. The adsorption isotherms were well fitted by the Freundlich equation. The correlation coefficients, $\mathrm{r}^{2}$, ranged from 0.96 to 0.99 for soils amended with AP350, CH350, CH500, Cy350, Cy500, L350, L500, and P350 biochars and $\mathrm{r}^{2}$ was between 0.73 to 0.77 for soils amended with AP500, BP350, BP500, and P500 biochars.

The $1 / \mathrm{n}_{\text {ads }}$ values of atrazine adsorption in the unamended soil and biochar amended soils were less than 1, suggesting that the adsorption isotherms were nonlinear and L-type (Table 3.2; Figures 3.1 and 3.2). The L-type isotherms generally indicate that adsorption is strongly dependent on the initial solution concentration and there is a decrease in adsorption at higher solution concentrations of the pesticide (Cabrera et al., 2011; GarcíaJaramillo et al., 2014). An increase in the degree of isotherm nonlinearity and L-type isotherms reflected that pore-filling was the primary mechanism for the sorption of atrazine by the biochar amended soils (Cabrera et al., 2011; García-Jaramillo et al., 2014). Soils amended with biochars made from cypress (Cy), loblolly pine (L), and pecan shell (P) at $350^{\circ} \mathrm{C}$ had $1 / \mathrm{n}_{\text {ads }}$ values greater $(0.60,0.60$, and 0.60 , respectively) than that of the unamended soil (0.59). But all other biochar amended soils had $1 / \mathrm{n}_{\text {ads }}$ values lower than that of the unamended soil, suggesting that these biochars had more condensed sorption domain to enhance affinity for atrazine (Deng et. al., 2014). 


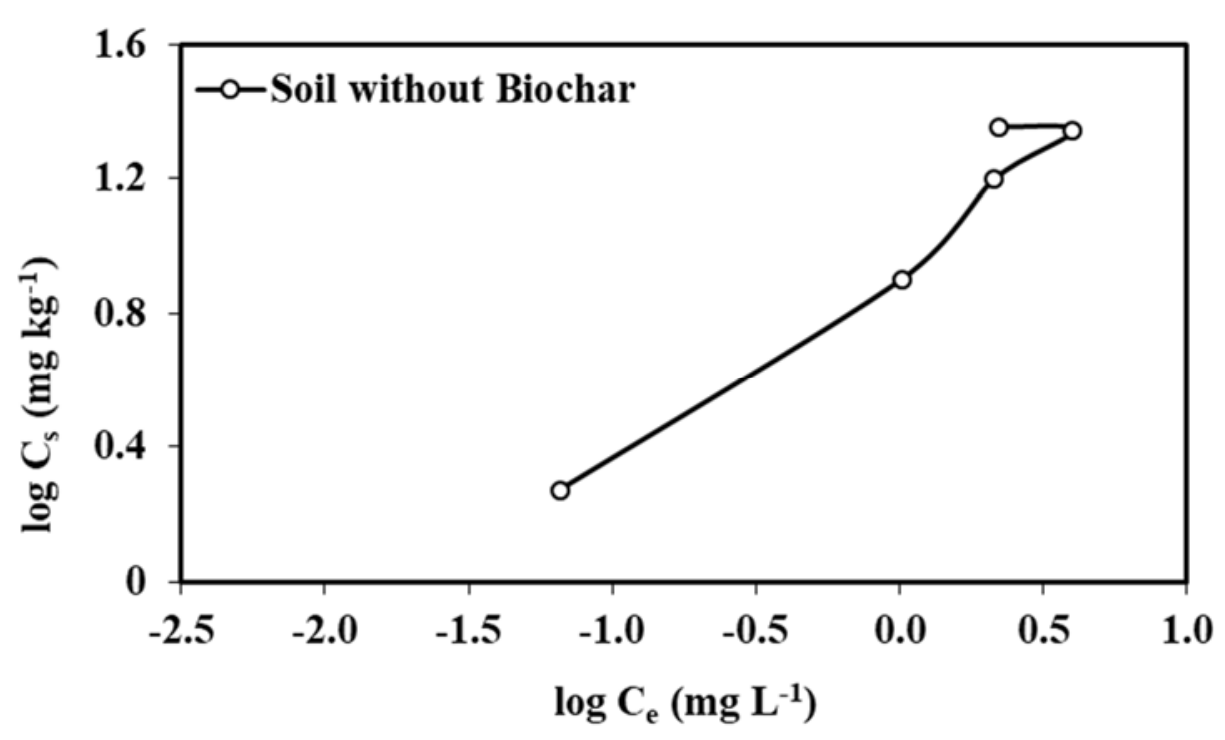

Figure 3. 1 The adsorption-desorption isotherms for atrazine calculated in soil without biochar.

The biochar amendments significantly influenced the adsorption of atrazine compared to the unamended soil. Overall, the $\mathrm{K}_{\mathrm{d}}$ ads values, which indicate the sorption affinity for atrazine (high value means higher affinity) were higher in biochars made from $\mathrm{AP}, \mathrm{CH}$, and $\mathrm{L}$ at $350^{\circ} \mathrm{C}$ and $500^{\circ} \mathrm{C}$, and from $\mathrm{BP}, \mathrm{Cy}$, and $\mathrm{P}$ at $500^{\circ} \mathrm{C}$ than the unamended soil (Table 3.2) likely because of higher SSA, TPV, and aromaticity (low H/C ratio) of those biochars (Tables 2.1 and 2.2). 

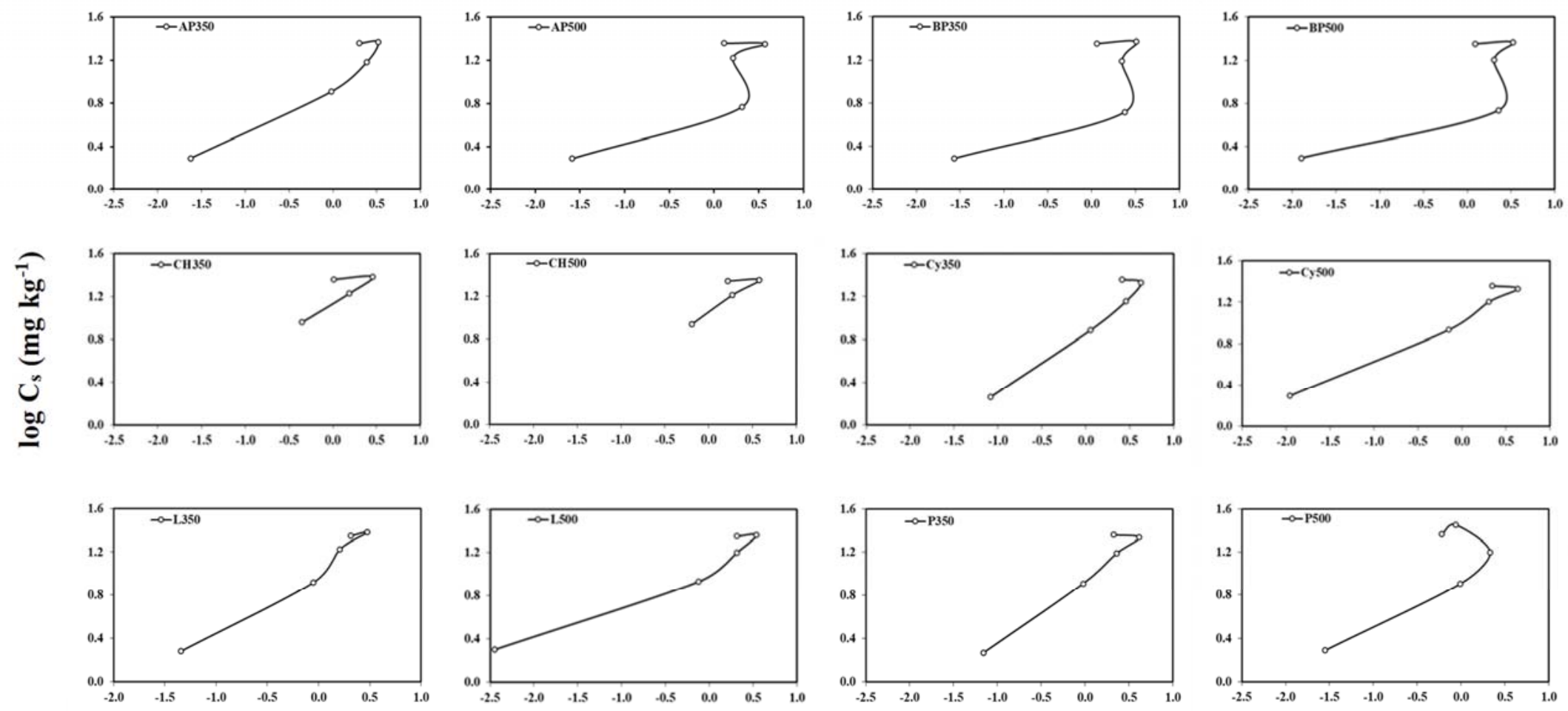

\section{$\log \mathrm{C}_{\mathrm{e}}\left(\mathrm{mg} \mathrm{L}^{-1}\right)$}

Figure 3. 2 The adsorption-desorption isotherms for atrazine calculated in soil amended with the twelve different biochars at $2 \%$ (w/w). AP350 \& AP500 $=$ Australian pine derived biochar pyrolyzed at $350^{\circ} \mathrm{C}$ and $500^{\circ} \mathrm{C}, \mathrm{BP} 350 \& \mathrm{BP} 500=$ Brazilian pepper derived biochar pyrolyzed at $350^{\circ} \mathrm{C}$ and $500^{\circ} \mathrm{C}$, $\mathrm{CH} 350$ \& $\mathrm{CH} 500=$ Coconut husk derived biochar pyrolyzed at $350^{\circ} \mathrm{C}$ and $500^{\circ} \mathrm{C}, \mathrm{Cy} 350$ \& $\mathrm{Cy} 500=$ Cypress derived biochar pyrolyzed at $350^{\circ} \mathrm{C}$ and $500^{\circ} \mathrm{C}, \mathrm{L} 350 \& \mathrm{~L} 500=$ Loblolly pine derived biochar pyrolyzed at $350^{\circ} \mathrm{C}$ and $500^{\circ} \mathrm{C}, \mathrm{P} 350 \& \mathrm{P} 500=$ Pecan shell derived biochar pyrolyzed at $350^{\circ} \mathrm{C}$ and $500^{\circ} \mathrm{C}$. 
Lower $\mathrm{K}_{\mathrm{d} \text { ads }}$ values of biochars made from $\mathrm{BP}$ and $\mathrm{Cy}$ at $350^{\circ} \mathrm{C}$ than the unamended soil suggest that these biochars may not be a viable option for atrazine adsorption in agricultural soils. The $\mathrm{K}_{\mathrm{d} \text { ads }}$ values can vary greatly in soil as a consequence of the influence of various soil components. Since soil OC is considered to be the primary soil component controlling the sorption of pesticide, the $\mathrm{K}_{\mathrm{d}}$ ads values were further normalized to Koc values for predicting better sorption behaviors of atrazine. The normalization assumes that $\mathrm{OM}$ is the primary soil property controlling adsorption, otherwise, there will be variation in the Koc values (Krutz et al., 2003). Greater Koc values of biochar amended soils than that of the unamended soil suggest that the biochars exhibit higher sorptivity to pesticide than the soil OC (Zhang et al., 2010; Hao et al., 2013). The Koc values of soils amended with biochars made from $\mathrm{AP}, \mathrm{CH}$, and $\mathrm{L}$ at $350^{\circ} \mathrm{C}$ and $500^{\circ} \mathrm{C}$, and from $\mathrm{BP}, \mathrm{Cy}$, and $\mathrm{P}$ at $500^{\circ} \mathrm{C}$ were greater than that of the unamended soil (Table 3.2) emphasizing greater affinity for atrazine by these biochars than the soil OM. Out of the 12 biochars, the Koc value for $\mathrm{CH} 350$ was significantly $(p<0.05)$ higher than the unamended soil. The Koc values of atrazine adsorption to biochars were in the range of 1 to 1.5 times higher than adsorption to soil. The addition of biochars in soils may have resulted in the increase of OC in soil which in turn, enhanced the adsorption of atrazine in the biochar amended soils. Similar results were observed in studies conducted by Hao et al. (2013) in China using corn cob biochars made at temperatures ranging from $350^{\circ} \mathrm{C}$ to $650^{\circ} \mathrm{C}$. Soil amended with biochars made from BP and $\mathrm{Cy}$ at $350^{\circ} \mathrm{C}$ had $\mathrm{Koc}$ values lower than that of the unamended soil, indicating possible interference of the higher OM content of soil in the sorption of atrazine by these biochars. The presence of OM in soils can decrease the sorption of organic compounds by biochar by blocking biochar pores or competing for biochar surface adsorption sites (Pignatello et 
al., 2006; Koelmans et al., 2009; Qui et al., 2009; Yu et al., 2011; Delwiche et al., 2014). Application of biochars made from $\mathrm{CH}$ and $\mathrm{L}$ at $350^{\circ} \mathrm{C}$ and $500^{\circ} \mathrm{C}$, from $\mathrm{AP}$ at $350^{\circ} \mathrm{C}$, and from $\mathrm{Cy}$ and $\mathrm{P}$ at $500^{\circ} \mathrm{C}$ increased the overall percentage of adsorption of atrazine in soil, with CH350 biochar amended soil having the highest (Table 3.2).

Table 3. 2 Adsorption parameters for atrazine in unamended soil and soils amended with the twelve different biochars at $2 \%(\mathrm{w} / \mathrm{w})$.

\begin{tabular}{|c|c|c|c|c|c|c|}
\hline Treatment & $\mathrm{K}_{\mathrm{fads}}{ }^{\ddagger}$ & $1 / \mathrm{nads}^{\S}$ & Freundlich $\mathrm{r}^{2}$ & $\mathrm{~K}_{\mathrm{d} \text { ads }}{ }^{\mathbb{2}}$ & $\mathrm{Koc}^{\#}$ & Adsorption (\%) \\
\hline Soil & $9.12 \pm 1.07$ & $0.59 \pm 0.04$ & 0.99 & $9.12^{\mathrm{BCDE}}$ & $101.53 \mathrm{BCDE}$ & $\begin{array}{c}73.24-93.44 \\
(81.25)^{\dagger \dagger}\end{array}$ \\
\hline Soil + AP350 & $10.47 \pm 1.15$ & $0.47 \pm 0.06$ & 0.96 & $10.47^{\mathrm{ABCDE}}$ & $116.56^{\mathrm{ABCDE}}$ & $\begin{array}{c}75.77-97.63 \\
(83.09)\end{array}$ \\
\hline Soil + AP500 & $9.17 \pm 1.48$ & $0.43 \pm 0.14$ & 0.77 & $9.17^{\mathrm{E}}$ & $102.09^{\mathrm{E}}$ & $\begin{array}{c}58.72-98.96 \\
(79.20)\end{array}$ \\
\hline Soil + BP350 & $8.32 \pm 1.45$ & $0.42 \pm 0.19$ & 0.72 & $8.32^{\mathrm{CDE}}$ & $92.63 \mathrm{CDE}$ & $\begin{array}{c}52.26-98.28 \\
(76.73)\end{array}$ \\
\hline Soil + BP500 & $9.33 \pm 1.45$ & $0.36 \pm 0.15$ & 0.73 & $9.33^{\mathrm{CDE}}$ & $103.87^{\mathrm{CDE}}$ & $\begin{array}{c}54.51-98.73 \\
(77.72)\end{array}$ \\
\hline Soil + CH350 & $13.80 \pm 1.02$ & $0.52 \pm 0.02$ & 0.99 & $13.80^{\mathrm{A}}$ & $153.63^{\mathrm{A}}$ & $\begin{array}{c}80.96-100.0 \\
\quad(90.31)\end{array}$ \\
\hline Soil + CH500 & $10.96 \pm 1.02$ & $0.54 \pm 0.02$ & 0.99 & $10.96^{\mathrm{ABC}}$ & $122.02 \mathrm{ABC}$ & $\begin{array}{c}75.03-100.0 \\
(87.05)\end{array}$ \\
\hline Soil + Cy350 & $7.94 \pm 1.05$ & $0.60 \pm 0.03$ & 0.99 & $7.94^{\mathrm{DE}}$ & $88.40^{\mathrm{DE}}$ & $\begin{array}{c}71.35-93.99 \\
(78.52)\end{array}$ \\
\hline Soil + Cy500 & $11.40 \pm 1.07$ & $0.40 \pm 0.03$ & 0.99 & $11.40^{\mathrm{ABCDE}}$ & $126.92 \mathrm{ABCDE}$ & $\begin{array}{c}71.32-98.90 \\
(83.97)\end{array}$ \\
\hline Soil + L350 & $11.39 \pm 1.12$ & $0.60 \pm 0.07$ & 0.98 & $11.39^{\mathrm{BCDE}}$ & $126.80^{\mathrm{BCDE}}$ & $\begin{array}{c}80.10-95.48 \\
(85.42)\end{array}$ \\
\hline Soil + L500 & $12.30 \pm 1.15$ & $0.33 \pm 0.05$ & 0.96 & $12.30^{\mathrm{ABCD}}$ & $136.93 \mathrm{ABCD}$ & $\begin{array}{c}76.84-99.65 \\
(85.12)\end{array}$ \\
\hline Soil + P350 & $9.12 \pm 1.02$ & $0.60 \pm 0.02$ & 0.99 & $9.12^{\mathrm{CDE}}$ & $101.53^{\mathrm{CDE}}$ & $\begin{array}{c}\text { 72.24-93.01 } \\
\quad(80.82)\end{array}$ \\
\hline Soil + P500 & $13.49 \pm 1.48$ & $0.52 \pm 0.21$ & 0.75 & $13.49^{\mathrm{AB}}$ & $150.18^{\mathrm{AB}}$ & $\begin{array}{c}78.45-97.18 \\
(87.53)\end{array}$ \\
\hline
\end{tabular}

Treatment abbreviations are the same as in Figure 3.2.

${ }^{*} \mathrm{~K}_{\mathrm{f} \text { ads }}=$ Freundlich sorption coefficient

$\S 1 / \mathrm{n}_{\mathrm{ads}}=$ Freundlich slope constant

${ }^{\top} \mathrm{K}_{\mathrm{d} \text { ads }}=$ Sorption coefficient estimated from the Freundlich sorption isotherms at equilibrium concentration $\left(\mathrm{C}_{\mathrm{e}}\right)$ of $1.0 \mathrm{mg} \mathrm{L}^{-1}$

${ }^{\#} \mathrm{~K}_{\mathrm{OC}}=\left(\mathrm{K}_{\mathrm{d} \text { ads }} / \% \mathrm{OC}\right) \times 100$, Sorption coefficient $\left(\mathrm{K}_{\mathrm{d} \text { ads }}\right)$ normalized to the organic carbon $(\mathrm{OC})$ content of the soil

tNumber in parentheses is the average adsorption by each treatment across the entire range of pesticide concentration

Numbers are mean \pm standard error

Means within a column followed by the same letter are not significantly different at $p<0.05$. 
The results suggest that coconut husk $(\mathrm{CH})$ had the highest adsorption (\%) of atrazine among the six feedstocks followed by loblolly pine (L) and pecan shell (P) compared to the unamended soil (Table 3.2). Only Brazilian pepper (BP) feedstock had lower $(5 \%$ but not significant at $p<0.05)$ atrazine adsorption than unamended soil for this experiment which was likely due to the very low CEC that was observed in biochars from BP feedstocks (Table 2.1). Overall, the atrazine adsorption capacity of biochars made from loblolly and pecan (native to Southeastern U.S.) was 7-10\% higher than biochars made from Australian pine and Brazilian pepper (non-native to Florida and invasive species) emphasizing that biochars produced from native plant species performed better in the same agroclimatic regions where they grow. Biochars from loblolly pine and pecan shell has been documented as effective adsorbents of organic compounds in previous studies (Jung et al., 2013; Komnitsas et al., 2016; Pan, 2020). Among all twelve biochars, CH350 performed best and had about 1.2 times higher $(p<0.05)$ adsorption than unamended soil possibly resulting from the highest CEC of CH350 (16.32 $\left.\mathrm{cmol} \mathrm{kg}^{-1}\right)$. Mandal et al. (2017) also observed that biochars (Oryza sativa, rice straw) with higher CEC resulted in higher adsorption of atrazine and imidacloprid pesticides. Coconut tree is very common in the tropical climate of Florida, USA, and specifically in South Florida (due to the shoreline and sea beaches), the abundance is much higher than other parts of the state. Therefore, it was assumed that large quantity biochar production from coconut husk in South Florida would be an effective solution of atrazine adsorption for other agricultural settings in the U.S. 
Desorption isotherms were also adequately described by the Freundlich adsorptiondesorption equation indicated by the correlation coefficient $\left(\mathrm{r}^{2}\right)$ values that ranged between 0.62 to 0.97 (Table 3.3 ).

Table 3. 3 Desorption parameters for atrazine in unamended soil and soils amended with the twelve different biochars at $2 \%(\mathrm{w} / \mathrm{w})$.

\begin{tabular}{ccccccc}
\hline Treatment & $\mathrm{K}_{\mathrm{fdes}}{ }^{\ddagger}$ & $1 / \mathrm{n}_{\text {des }}{ }^{\S}$ & Freundlich $\mathrm{r}^{2}$ & $\mathrm{~K}_{\mathrm{ddes}}{ }^{\circledR}$ & $\mathrm{H}^{\#}$ & $\begin{array}{c}\text { Desorption } \\
(\%)\end{array}$ \\
\hline Soil & $10.00 \pm 1.22$ & $0.62 \pm 0.07$ & 0.96 & 10.00 & $1.07^{\mathrm{A}}$ & 3.52 \\
Soil + AP350 & $11.48 \pm 1.15$ & $0.49 \pm 0.07$ & 0.94 & 11.48 & $1.04^{\mathrm{AB}}$ & 2.69 \\
Soil + AP500 & $10.72 \pm 1.35$ & $0.45 \pm 0.17$ & 0.70 & 10.72 & $1.05^{\mathrm{B}}$ & 2.30 \\
Soil + BP350 & $10.00 \pm 1.41$ & $0.43 \pm 0.19$ & 0.62 & 10.00 & $1.02^{\mathrm{AB}}$ & 3.19 \\
Soil + BP500 & $10.96 \pm 1.38$ & $0.38 \pm 0.16$ & 0.66 & 10.96 & $1.06^{\mathrm{A}}$ & 3.12 \\
Soil + CH350 & $16.98 \pm 1.12$ & $0.48 \pm 0.18$ & 0.70 & 16.98 & $0.92^{\mathrm{AB}}$ & 2.11 \\
Soil + CH500 & $15.85 \pm 1.09$ & $0.54 \pm 0.11$ & 0.79 & 15.85 & $1.00^{\mathrm{AB}}$ & 6.03 \\
Soil + Cy350 & $8.71 \pm 1.12$ & $0.64 \pm 0.08$ & 0.95 & 8.71 & $1.07^{\mathrm{AB}}$ & 2.82 \\
Soil + Cy500 & $12.30 \pm 1.09$ & $0.42 \pm 0.04$ & 0.97 & 12.30 & $1.05^{\mathrm{AB}}$ & 2.66 \\
Soil + L350 & $12.02 \pm 1.09$ & $0.61 \pm 0.06$ & 0.97 & 12.02 & $1.02^{\mathrm{AB}}$ & 4.94 \\
Soil + L500 & $13.49 \pm 1.12$ & $0.35 \pm 0.05$ & 0.95 & 13.49 & $1.06^{\mathrm{AB}}$ & 4.45 \\
Soil + P350 & $9.77 \pm 1.12$ & $0.63 \pm 0.08$ & 0.96 & 9.77 & $1.05^{\mathrm{AB}}$ & 2.26 \\
Soil + P500 & $15.85 \pm 1.41$ & $0.53 \pm 0.21$ & 0.68 & 15.85 & $1.02^{\mathrm{AB}}$ & 1.20 \\
\hline
\end{tabular}

Treatment abbreviations are the same as in Figure 3.2.

${ }^{*} \mathrm{~K}_{\mathrm{fdes}}=$ Freundlich sorption coefficient

$\S 1 / \mathrm{n}_{\text {des }}=$ Freundlich slope constant

${ }^{\top} \mathrm{K}_{\mathrm{d} \text { des }}=$ Sorption coefficient estimated from the Freundlich sorption isotherms at equilibrium concentration $\left(\mathrm{C}_{\mathrm{e}}\right)=1.0 \mathrm{mg} \mathrm{\textrm {L } ^ { - 1 }}$

${ }^{\#} \mathrm{H}=\left(1 / \mathrm{n}_{\mathrm{des}}\right) /\left(1 / \mathrm{n}_{\mathrm{ads}}\right)$, Hysteresis coefficient

Numbers are mean \pm standard error

Means within a column followed by the same letter are not significantly different at $p<0.1$.

Larger $K_{d}$ des values indicate a greater proportion of the pesticide is retained by the biochar amended soils following the desorption experiment compared to the unamended soil. (Krutz et al., 2003; Ghosh and Singh, 2013). Overall $\mathrm{K}_{\mathrm{d} \text { des }}$ values for atrazine were $16 \%$ higher than $\mathrm{K}_{\mathrm{d} \text { ads }}$ values showing a considerable amount of the atrazine that was adsorbed by the biochar amended soils were retained following the desorption experiment. Since the $\mathrm{K}_{\mathrm{d} \text { des }}$ values of soils amended with biochars made from $\mathrm{AP}, \mathrm{CH}$, and $\mathrm{L}$ at $350^{\circ} \mathrm{C}$ 
and $500^{\circ} \mathrm{C}$, and from $\mathrm{BP}$ and $\mathrm{P}$ at $500^{\circ} \mathrm{C}$ were higher than the unamended soil (Table 3.3), it can be assumed that these biochars retained higher amount of adsorbed atrazine than the unamended soil.

The Freundlich $1 / \mathrm{n}_{\text {des }}$ values represent the nonlinearity of the desorption isotherms and are an index for the desorption intensity. The difference between desorption and adsorption isotherms for soils with and without biochars is indicative of hysteresis. Hysteresis provides information on the reversibility of adsorption which is crucial in determining the mobility of the pesticides in the soil profile. The hysteresis index $(\mathrm{H})$, calculated as the ratio between $1 / \mathrm{n}_{\text {des }}$ and $1 / \mathrm{n}_{\text {ads }}$, is positive when the value is less than 1 and is negative when it is greater than 1. Positive hysteresis was observed in soil amended with coconut husk biochar $(\mathrm{CH})$, where, the $\mathrm{H}$ value for $\mathrm{CH} 350$ biochar amended soil was less than 1 (Table 3.3) implying that it was difficult to desorb atrazine that had already been sorbed by this biochar. The hysteresis that occurred may be the result of the irreversible binding of atrazine on biochars in sorption sites or because of the entrapment in the porous structure of biochars, which made it difficult for the atrazine molecule to be washed out (Bhanderi et al., 1996; Yu et al., 2006). In the present study, the 1/ndes values were slightly higher than the $1 / \mathrm{n}_{\text {ads }}$ values for the unamended soil and soils amended with biochars made from $\mathrm{AP}, \mathrm{BP}, \mathrm{Cy}, \mathrm{L}$, and $\mathrm{P}$ biochars, resulting in $\mathrm{H}$ values higher than 1 . Therefore, negative hysteresis was observed in these cases indicating that the rate of desorption was slightly higher than the rate of adsorption. In general, the adsorption mechanism greatly influences hysteresis. After being adsorbed, some amount of the adsorbate may further react with the adsorbent surface (involving several interaction mechanisms) depending on their properties and the number of heterogeneous adsorbing sites on biochars and soil with 
different adsorption energies (Raman et al., 1988; Ghosh and Singh, 2013). The percentage of desorption for soil amended with biochars made from $\mathrm{CH}$ at $500^{\circ} \mathrm{C}$ and from $\mathrm{L}$ at $350^{\circ} \mathrm{C}$ and $500^{\circ} \mathrm{C}$ were higher than the unamended soil (Table 3.3). The sorption of atrazine is pH-dependent and desorption increases with an increase in pH (Liu et al. 1995; Ghosh and Singh, 2013; Deng et al. 2014). The pH of CH500 (9.89), L350 (7.63), and L500 (7.84) biochars were higher than the unamended soil (7.52), which may have attributed towards the higher percentage of desorption observed by these biochars (Table 2.1). The lowest percentage of desorption was observed in P500 biochar amended soil (1.20\%), which had the second highest adsorption (Tables 3.2 and 3.3), indicating that this biochar was able to retain the maximum amount of the adsorbed atrazine, which can help in reducing further surface and ground water contamination. Therefore, pecan shell $(\mathrm{P})$, which is considered as an agricultural waste, can also be considered an effective feedstock for the mass production of biochar that can be used to reduce atrazine contamination in the environment.

\subsection{Environmental Implications}

Despite causing surface and groundwater contaminations, Atrazine is still one of the most widely used pesticides in the world. In fact, it is the second most commonly used pesticide in the U.S. agriculture and its sale at present is still steadily maintained at 70-80 million pounds per year (Grube et al., 2004). The maximum contaminant level (MCL) for atrazine in drinking water established by US-EPA is $3.0 \mu \mathrm{g} / \mathrm{L}$ and the European Union requires the MCL below $0.1 \mu \mathrm{g} / \mathrm{L}$ for a single pesticide in drinking water. As atrazine has a half-life of one to twelve months in the environment and can persist in soil for up to a decade (Naseri et al. 2009), it has been frequently detected in Spanish, European and American surface and groundwater resources at concentrations many times above the 
$0.1 \mu \mathrm{g} \mathrm{L}{ }^{-1}$ groundwater quality standard for individual pesticides or $0.5 \mu \mathrm{g} \mathrm{L}^{-1}$ for the sum of several pesticides (Sun et al., 2010; Barco-Bonilla et al., 2013; Moreno-Gonzalez et al., 2013; Mandal and Singh, 2017). It is well known that atrazine is a highly mobile toxic to aquatic organisms, plants, and human beings (Lasserre et al., 2009). The use of biochar as an adsorbent offers great potential for removing pesticides from the environment in an efficient and cost-effective manner. A study conducted in Minnesota, USA by Spokas et al. (2009) reported the high adsorption capacity of 5\% (w/w) sawdust biochars produced at $500^{\circ} \mathrm{C}$ to atrazine and acetochlor in a sandy loam soil sample. Results from Delwiche et al. (2014) using biochars made from pine wood chip pyrolyzed between $300^{\circ} \mathrm{C}$ to $550^{\circ} \mathrm{C}$ resulted in a decrease in the leaching of atrazine from a homogenized soil column by $52 \%$. A study conducted in China by Deng et al. (2014) using manioc waste derived biochars at $750^{\circ} \mathrm{C}$ showed that the addition of biochars to soil increased the sorption of atrazine by about 17.5 times. Huang et al. (2018) conducted a study in China using biochars made from sugarcane at $500^{\circ} \mathrm{C}$, where the addition of biochars increased the adsorption of atrazine by $27 \%$ in a moist soil with a low level of total organic carbon while it increased by $32 \%$ in a paddy soil with high total organic carbon. In all studies, the high adsorption of atrazine was attributed to the high SSA, porous structure, and aromaticity of the biochars. It is evident that biochars produced from different feedstocks have various physiochemical properties that greatly influence the sorption capacity for pesticides. In general, the high SSA, carbonaceous nature, hydrophobicity, and porous structure of the biochar play an important role in effectively influencing the sorption of pesticides. In the current study the CEC of the biochars, in addition to SSA, TPV, and aromaticity influenced the higher adsorption of atrazine. Despite the high indigenous SOM, the biochar 
amendments enhanced the adsorption of atrazine as indicated by the Koc values. The higher observed adsorption by biochars made from $\mathrm{AP}, \mathrm{CH}$, and $\mathrm{L}$ at $350^{\circ} \mathrm{C}$ and $500^{\circ} \mathrm{C}, \mathrm{BP}, \mathrm{Cy}$ and, $\mathrm{P}$ at $500^{\circ} \mathrm{C}$ than unamended soil indicate the effectiveness of these biochars in retaining atrazine thus reducing further surface and ground water contamination. The current study shows that out of the six different feedstocks, $\mathrm{CH}$ and P derived biochars performed best as reflected by the comparatively higher adsorption capacity and low desorption percentage, respectively. The results from the study demonstrate that the use of invasive plant species (AP and $\mathrm{BP})$ and agricultural residues $(\mathrm{CH}$ and $\mathrm{P})$ for the production of biochars and its application will provide a cost-effective and eco-friendly approach to deal with pesticide contamination in the environment.

\subsection{Conclusion}

Atrazine is a very effective and widely used herbicide in the U.S. and generates higher economic return from crop production when applied in agricultural fields. However, it is highly mobile and can easily be lost from the soil profile to subsequently cause groundwater contamination. A significant amount of atrazine concentration in drinking water resources were reported which has the potentiality to cause human health issues and several environmental quality problems. The current study assessed the effects of biochars produced from various feedstocks and their comparative ability to retain atrazine in the soil surface. Agricultural waste materials are often difficult to manage, and it was found that biochars made from coconut husk (a waste product of coconut) performed best for controlling the sorption behavior of atrazine in the soil. Other biochars from native plant species (loblolly pine and pecan shell) also performed well and about $7-10 \%$ better in increasing atrazine adsorption compared to biochars from invasive plant species 
(Australian pine and Brazilian pepper) which indicates that climatic conditions may have more effect on the performance of the biochars in agricultural soil. The biochar amendments significantly influenced the adsorption of atrazine compared to the unamended soil. Cation exchange capacity and specific surface area were the two major properties of the biochars that contributed towards their potentiality in atrazine sorption isotherms. The results indicate that type of feedstocks and agroclimatic conditions had greater effects on biochar performance than the production temperature of those biochars. 


\section{CHAPTER 4: INVESTIGATING THE EFFECT OF TWELVE DIFFERENT BIOCHARS}

ON THE GROWTH OF Capsicum annuum 'JALAPENO', SOIL MICROBIAL POPULATION, AND ENZYME ACTIVITY

Abstract

In recent years biochar is being applied extensively to agricultural soils because of the potential influence on plant productivity, microorganisms, and enzyme activity in soil. This study was conducted to observe the effects of twelve biochar treatments (made from six different feedstocks at $350^{\circ} \mathrm{C}$ and $500^{\circ} \mathrm{C}$ ) on Jalapeno pepper (Capsicum annuum 'Jalapeno') growth, soil bacteria and fungi population, mycorrhizal fungi root colonization and soil enzyme activity. The biochar treatments did not significantly influence the growth and yield of Jalapeno pepper plant compared to the control, however there was significant difference in the influence among different biochar treatments. Biochars made from Brazilian pepper at $500^{\circ} \mathrm{C}$ (T6) performed best in affecting plant growth and yield. An overall increase in the bacteria $(10 \%)$ population with a decrease in fungi $(8 \%)$ population in soil resulted from the effects of biochar treatments $(p<0.05)$ over the entire growing period of Jalapeno. The treatments containing biochars made from coconut husk (T7 and T8) had the highest number of bacteria colonies in soil collected at 40 days after planting (DAP) Jalapeno which was $9.5 \%$ significantly $(p<0.05)$ higher than the bacteria colonies observed in the control (T2). However, at 90 DAP a 3.8\% reduction in bacteria population was observed in soils treated with these biochars, possibly resulting from the unfavorable effects of the comparatively high volatile matter content of these biochars. Treatments containing biochars made from Brazilian pepper at $350^{\circ} \mathrm{C}(\mathrm{T} 5)$ and biochars made from loblolly pine at $350^{\circ} \mathrm{C}(\mathrm{T} 10)$ resulted in a $12 \%$ and $8 \%$, respectively, increase in fungi 
population compared to the control at 90 DAP. Treatments containing coconut husk biochars (T7 and T8), loblolly pine biochar (T9 and T10), cypress biochars (T11 and T12), and pecan shell biochars (T13 and T14) resulted in 159\%, 169\%, 203\%, and 179\%, respectively, significantly $(p<0.05)$ higher root colonization by AM fungi in comparison to the control (T2). The treatment containing cypress biochars made at $350^{\circ} \mathrm{C}$ (T11) showed the significantly highest (3.5 times) alkaline phosphatase enzyme activity in soil compared to the control (T2). $\beta$-N-acetylglucosaminidase enzyme activity in soils was significantly higher (19 times) compared to the control (T2) caused by the treatments containing Brazilian pepper biochars made at $500^{\circ} \mathrm{C}$. (T6). However, there was no significant effect of biochar on the $\beta-1-4$-glucisidase enzyme activity in soil. The specific sorption behavior (specific surface area, cation exchange capacity), pore structure (total pore volume, average pore size), $\mathrm{pH}$, ash and volatile matter content were the major biochar properties that influenced the effects of the biochar treatments. The type feedstock had greater effect on the biochar performance than the selected production temperature.

\subsection{Introduction}

As a soil conditioner biochars have the ability to affect plant growth by supplying and more importantly retaining nutrients and by improving soil physical and biological properties (Downie et al., 2009). However, the effectiveness of biochars for enhancing plant production depends not only on the type of soil, crops, climatic conditions (Blackwell et al., 2009; Obia et al., 2016) but also is influenced by the properties of the biochars (Van Zwieten et al., 2009; Cayuela et al., 2014; Jeffery et al., 2011). The inherent variability of biochars due to different feedstock and production conditions implies a high variability of their effect on soil properties and productivity (Novak and Busscher, 2013; Zhao et al., 
2013). As a result, the effects of biochar on crop production are rather variable (Borchard et al., 2014; Jeffery et al., 2011; Schultz and Glaser, 2012).

Soil organism activity is crucial to maintaining soil conditions and enhancing plant development. Biochar pores serve as a habitat to soil microorganisms such as bacteria (size range from 0.3 to $3 \mathrm{~mm}$ ), fungi $(2-80 \mathrm{~mm})$, and protozoa $(7-30 \mathrm{~mm}$ ) (Zackrisson et al., 1996; Pietikainen et al., 2000; Warnock et al., 2007; Quilliam et al., 2013; Jaafar et al., 2014) and also protect them from predators (Zackrisson et al., 1996; Warnock et al., 2007). Biochar macropores (> $200 \mathrm{~nm}$ ) represent majority of the protected microbial habitats due to the size to accommodate bacteria, although biochar also contains micropores $(<2 \mathrm{~nm})$ and mesopores $(2-50 \mathrm{~nm})$ that could store water and dissolved substances that are needed for microbial metabolism (Quilliam et al., 2013). The abundance and size of these pores depends on the production temperature of the biochar as well as biochar feedstocks (Shaaban et al. 2014).

The effects of biochar on soil fungi and especially mycorrhizal fungi have received greater attention. A study conducted by Ishii and Kadoya (1994) showed that biochar can have positive effects on the abundance of arbuscular mycorrhizal (AM) fungi. In another study by Warnock et al. (2007) it was found that AM fungi were positively affected by biochar. However, some studies have also found that biochar can negatively affect AM fungi abundance (Gaur and Adholeya, 2000; Birk et al., 2009; Warnock et al., 2010).

Microbially produced extracellular enzymes are important for organic matter decomposition and nutrient cycling for microbial as well as plant uptake (Burns et al., 2013). Therefore, the influence of biochar on activities of soil extracellular enzymes is important. Studies reveal variable effect of biochars on extracellular enzyme activities 
(Bailey et al., 2011; Awad et al., 2012; Paz-Ferreiro et al., 2012; Ameloot et al., 2013; Masto et al., 2013). The influence of biochar on soil enzyme activity depends on the interaction of substrate and enzyme with biochar, that is, sorption and desorption of substrates on biochar cation and anion exchange sites, binding of extracellular enzymes to the biochar surface and is related to the porosity and surface area of biochar (Lammirato et al., 2011). Biochar with greater porosity and surface area is expected to reduce extracellular enzyme activity, since functional groups on such biochar would tend to bind substrates and extracellular enzymes, thus interfering with the rate of substrate diffusion to the active site of enzyme catalysis (Bailey et al., 2011; Lammirato et al., 2011).

Similar to plant response, the variability in biochar properties together with the variation in soil types strongly affect microbial and enzyme activities in soil, thus, warrants intensive research to better understand the role of different biochar applications. Even though a number of studies have been conducted on biochar amendments in soils, the use and effect of biochars on plant and soil microorganisms in organic rich soils have been little studied. Therefore, this study was designed to investigate the plant and microbial response and enzyme activity in an organic rich soil, following the addition of twelve biochars from different feedstocks.

\subsection{Materials and Methods}

\subsubsection{Biochars used in this study}

The twelve biochars used in this study was produced from six feedstocks pyrolyzed at temperatures $350^{\circ} \mathrm{C}$ and $500^{\circ} \mathrm{C}$. The feedstocks consisted of Australian pine (Casaurina equisetifolia), Brazilian pepper (Schinus terebinthifolius), coconut husk (Cocos nusifera), cypress (Taxodium distichum), loblolly pine (Pinus taeda), and pecan shell (Carya illinoinensis). The 
biochars were denoted based on the feedstock and production temperature, such as AP350 indicated Australian pine derived biochars pyrolyzed at $350^{\circ} \mathrm{C}$ and so on. The biochars have been characterized in chapter 2 and selected physicochemical properties are listed in Table 4.1.

\subsubsection{Site description and Experimental design}

The potted experiment was conducted at the Organic Garden shade house $\left(25.7540^{\circ} \mathrm{N}\right.$, $80.3801^{\circ} \mathrm{W}$ ) located near the nature preserve at Florida International University (FIU), Miami, FL, USA, between 22 March and 25 June 2019. Treatments for this study were laid out according to a randomized complete block design (RCBD). Treatments consisted of $\mathrm{T} 1=$ No Biochar + No Hoagland's nutrient solution $(\mathrm{HNS}), \mathrm{T} 2(\mathrm{Control})=$ No Biochar + HNS, T3 $=$ AP350 + HNS (Australian pine derived biochar pyrolyzed at $350^{\circ} \mathrm{C}$ ), T4 $=$ AP500 + HNS (Australian pine derived biochar pyrolyzed at $500^{\circ} \mathrm{C}$ ), T5 $=\mathrm{BP} 350+\mathrm{HNS}$ (Brazilian pepper derived biochar pyrolyzed at $350^{\circ} \mathrm{C}$ ), $\mathrm{T} 6=\mathrm{BP} 500+\mathrm{HNS}\left(\right.$ Brazilian pepper derived biochar pyrolyzed at $\left.500^{\circ} \mathrm{C}\right), \mathrm{T} 7=\mathrm{CH} 350$ + HNS (Coconut husk derived biochar pyrolyzed at $350^{\circ} \mathrm{C}$ ), T8 $=\mathrm{CH} 500+\mathrm{HNS}$ (Coconut husk derived biochar pyrolyzed at $500^{\circ} \mathrm{C}$ ), $\mathrm{T} 9=\mathrm{L} 350+\mathrm{HNS}$ (Loblolly pine derived biochar pyrolyzed at $350^{\circ} \mathrm{C}$ ), $\mathrm{T} 10=\mathrm{L} 500+\mathrm{HNS}$ (Loblolly pine derived biochar pyrolyzed at $500^{\circ} \mathrm{C}$ ), $\mathrm{T} 11=\mathrm{Cy} 350$ + HNS (Cypress derived biochar pyrolyzed at $350^{\circ} \mathrm{C}$ ), T12 $=$ Cy500 + HNS (Cypress derived biochar pyrolyzed at $500^{\circ} \mathrm{C}$ ), T13 $=\mathrm{P} 350+\mathrm{HNS}$ (Pecan shell derived biochar pyrolyzed at $350^{\circ} \mathrm{C}$ ), $\mathrm{T} 14=\mathrm{P} 500+\mathrm{HNS}\left(\right.$ Pecan shell derived biochar pyrolyzed at $\left.500^{\circ} \mathrm{C}\right)$. Each treatment had 5 replications. Details of the experimental lay out is presented in Figure 4.1. 
Table 4. 1 Selected physicochemical properties of the twelve different biochars used as treatments for the pot experiments.

\begin{tabular}{cccccccccc}
\hline Sample & $\begin{array}{c}\text { Volatile } \\
\text { Matter } \\
(\%)\end{array}$ & $\begin{array}{c}\text { Ash } \\
(\%)\end{array}$ & $\mathrm{pH}$ & $\begin{array}{c}\mathrm{CEC}^{\ddagger} \\
\left(\mathrm{cmol} \mathrm{kg}^{-1}\right)\end{array}$ & $\begin{array}{c}\mathrm{SSA}^{\S} \\
\left(\mathrm{m}^{2} / \mathrm{g}\right)\end{array}$ & $\begin{array}{c}\mathrm{TPV} \\
\left(\mathrm{cm}^{3} / \mathrm{g}\right)\end{array}$ & $\begin{array}{c}\text { Average } \\
\text { pore size } \\
(\mathrm{nm})\end{array}$ & Carbon (\%) & Nitrogen $(\%)$ \\
\hline AP350 & 79.24 & 5.32 & 8.58 & 16.31 & 0.98 & 0.003 & 12.46 & 64.93 & 0.94 \\
AP500 & 61.35 & 10.19 & 9.37 & 8.19 & 2.59 & 0.006 & 9.40 & 66.65 & 1.10 \\
BP350 & 66.47 & 2.06 & 7.72 & 8.47 & 0.57 & 0.002 & 12.26 & 67.54 & 0.5 \\
BP500 & 55.80 & 4.02 & 9.65 & 7.92 & 2.29 & 0.008 & 14.60 & 77.37 & 0.51 \\
CH350 & 85.05 & 3.74 & 9.40 & 16.32 & 0.89 & 0.003 & 13.31 & 66.69 & 0.51 \\
CH500 & 79.37 & 8.88 & 9.89 & 12.04 & 1.94 & 0.004 & 7.99 & 67.00 & 0.69 \\
L350 & 71.31 & 1.70 & 7.63 & 8.51 & 0.30 & 0.001 & 12.81 & 67.71 \\
L500 & 48.59 & 3.20 & 7.84 & 7.93 & 5.21 & 0.004 & 3.13 & 79.47 & 0.5 \\
Cy350 & 72.75 & 0.55 & 7.11 & 10.55 & 0.41 & 0.001 & 10.01 & 76.10 & 0.5 \\
Cy500 & 62.66 & 1.59 & 7.67 & 9.18 & 4.18 & 0.002 & 2.39 & 83.59 & 0.5 \\
P350 & 68.04 & 2.18 & 7.36 & 6.14 & 0.36 & 0.001 & 14.56 & 68.45 & 0.5 \\
P500 & 56.33 & 3.82 & 7.94 & 4.66 & 2.14 & 0.002 & 4.41 & 78.96 & 0.5 \\
\hline
\end{tabular}

Sample abbreviation are as follows

AP350 \& AP500 = Australian pine derived biochar pyrolyzed at $350^{\circ} \mathrm{C}$ and $500^{\circ} \mathrm{C}$; BP350 \& $\mathrm{BP} 500=$ Brazilian pepper derived biochar pyrolyzed at $350^{\circ} \mathrm{C}$ and $500^{\circ} \mathrm{C}$; $\mathrm{CH} 350 \& \mathrm{CH} 500=$ Coconut husk derived biochar pyrolyzed at $350^{\circ} \mathrm{C}$ and $500^{\circ} \mathrm{C}$; Cy $350 \& \mathrm{Cy} 500=\mathrm{Cypress}$ derived biochar pyrolyzed at $350^{\circ} \mathrm{C}$ and $500^{\circ} \mathrm{C}$; L350 \& L500 = Loblolly pine derived biochar pyrolyzed at $350^{\circ} \mathrm{C}$ and $500^{\circ} \mathrm{C}$; P350 \& P500 = Pecan shell derived biochar pyrolyzed at $350^{\circ} \mathrm{C}$ and $500^{\circ} \mathrm{C}$

CEC = Cation Exchange Capacity

${ }_{\mathrm{SSA}}=$ Specific surface area

TPV $=$ Total pore volume 


\begin{tabular}{ccccccccccccccc} 
Replications & \multicolumn{1}{c}{ Treatments } \\
R1 & T9 & T5 & T10 & T4 & T6 & T2 & T14 & T7 & T8 & T1 & T13 & T3 & T11 & T12 \\
R2 & T13 & T3 & T4 & T11 & T5 & T6 & T1 & T8 & T10 & T2 & T14 & T12 & T9 & T7 \\
R3 & T6 & T2 & T8 & T13 & T4 & T5 & T3 & T14 & T12 & T9 & T11 & T11 & T7 & T1 \\
R4 & T1 & T4 & T14 & T3 & T10 & T11 & T5 & T12 & T13 & T8 & T7 & T7 & T6 & T9 \\
R5 & T8 & T14 & T5 & T6 & T4 & T13 & T11 & T1 & T3 & T10 & T9 & T9 & T2 & T12
\end{tabular}

Figure 4. 1 Experimental layout of the shade house experiment. Treatments are as follows:

T1 = No Biochar + No Hoagland's No.2 basal salt solution (HNS)

$\mathrm{T} 2(\mathrm{Control})=$ No Biochar + HNS

$\mathrm{T} 3=\mathrm{AP} 350+\mathrm{HNS}$ (Australian pine derived biochar pyrolyzed at $350^{\circ} \mathrm{C}$ )

$\mathrm{T} 4=\mathrm{AP} 500+\mathrm{HNS}$ (Australian pine derived biochar pyrolyzed at $500^{\circ} \mathrm{C}$ )

$\mathrm{T} 5=\mathrm{BP} 350+\mathrm{HNS}\left(\right.$ Brazilian pepper derived biochar pyrolyzed at $\left.350^{\circ} \mathrm{C}\right)$

$\mathrm{T} 6=\mathrm{BP} 500+\mathrm{HNS}$ (Brazilian pepper derived biochar pyrolyzed at $500^{\circ} \mathrm{C}$ )

$\mathrm{T} 7=\mathrm{CH} 350+\mathrm{HNS}\left(\right.$ Coconut husk derived biochar pyrolyzed at $\left.350^{\circ} \mathrm{C}\right)$

$\mathrm{T} 8=\mathrm{CH} 500+\mathrm{HNS}\left(\right.$ Coconut husk derived biochar pyrolyzed at $\left.500^{\circ} \mathrm{C}\right)$

$\mathrm{T} 9=\mathrm{L} 350+\mathrm{HNS}$ (Loblolly pine derived biochar pyrolyzed at $350^{\circ} \mathrm{C}$ )

$\mathrm{T} 10=\mathrm{L} 500+\mathrm{HNS}$ (Loblolly pine derived biochar pyrolyzed at $500^{\circ} \mathrm{C}$ )

$\mathrm{T} 11=\mathrm{Cy} 350+\mathrm{HNS}\left(\right.$ Cypress derived biochar pyrolyzed at $\left.350^{\circ} \mathrm{C}\right)$

$\mathrm{T} 12=\mathrm{Cy} 500+\mathrm{HNS}\left(\right.$ Cypress derived biochar pyrolyzed at $\left.500^{\circ} \mathrm{C}\right)$

$\mathrm{T} 13=\mathrm{P} 350+\mathrm{HNS}\left(\right.$ Pecan shell derived biochar pyrolyzed at $\left.350^{\circ} \mathrm{C}\right)$

$\mathrm{T} 14=\mathrm{P} 500+\mathrm{HNS}\left(\right.$ Pecan shell derived biochar pyrolyzed at $\left.500^{\circ} \mathrm{C}\right)$

Treatments were arranged in a randomized complete block design (RCBD). Each treatment had 5 replications.

\subsubsection{Soil collection and preparation}

Soil used for this study was collected from the garden research plot at FIU. It is classified as a Krome loamy-skeletal, carbonatic, hyperthermic lithic Udorthent, according to the USDA-NRCS Soil Series Classification Database (Velez et al., 2018). The soil had a pH of 7.52 and consisted of $9.9 \%$ carbon, $0.55 \%$ nitrogen, $15.5 \%$ organic matter, $76 \%$ sand, $22 \%$ silt and $2 \%$ clay. The research plot soils received compost produced onsite at an undetermined rate. Cover crops were also incorporated into the soil. These attributed to the high organic matter content of the soil. The soil collected in March 2019 was passed through a $4 \mathrm{~mm}$ opening sieve, homogenized and amended with the twelve different biochars. Soils received biochars at the rate of $22.5 \mathrm{t} / \mathrm{ha}$ soil $(1 \%, \mathrm{w} / \mathrm{w})$. Approximately 6 
$\mathrm{kg}$ of soil (dry weight basis) was lightly packed into 2-gallon nursery pots (7.6 L). Miracle grow (20N:8.7P:16.7K) was added as starter fertilizer at the time of planting seeds in the pots and approximately $500 \mathrm{ml}$ of Hoagland's No.2 basal salt (with macro- and micronutrients) solution (HNS) (Johnson et al., 1996) was also added to each pot twice a week to eliminate nutrient limitations over the course of the growing period. Water was added every other day except on days when there was rain. Pots consisting treatment T1 did not receive any starter fertilizer or HNS.

\subsubsection{Potted plant experiment and plant parameter analysis}

Jalapeno pepper (Capsicum annuum 'Jalapeno') was used as the plant for this study. It is one of the popular crops grown in Florida, USA. The U.S. demand for Jalapeno rises every year because of the growing popularity of ethnic cuisine (Ozores-Hampton and McAvoy, 2014). The low calories and rich vitamins, minerals, fiber, antioxidants and bioactive compounds in Jalapeno are reported to have many health benefits including reduced risk of death due to cardiovascular diseases, tumor development and cancer (Agudo et. al., 2007; Nomura et. al., 2008; Liu et. al., 2000). Four seeds per pot were placed a few centimeters apart and about an inch deep on 22 March 2019. After seedlings emerged the plants were thinned to one per pot. To evaluate the effects of the biochar treatments on plant, selected parameters were measured throughout the growing duration of Jalapeno using methods adapted from Gravel et al. (2013) and Liu et al. (2019). Plant height (cm) and number of leaves were measured at 4, 6, 8, 10,12 and 14 weeks after planting (WAP). Height was measured from the first cotyledon's node as a reference point to the uppermost leaf node. The average leaf chlorophyll content was measured using Soil Plant Analysis Development (SPAD) 502 Plus Chlorophyll meter at 6, 8, 10, 12 and 14 WAP. Fruits were 
harvested 90 days after planting (DAP). Yield was recorded from the weight (fresh) and number of fruits per treatment. The plants were removed from pots at $14 \mathrm{WAP}$ and the leaves, branches and roots were collected for analysis. Roots were washed thoroughly to remove soil prior to any experiment. All samples were oven dried at $70^{\circ} \mathrm{C}$ for 72 hours to estimate leaf, branch, shoot and root dry biomass weight.

\subsubsection{Enumeration of soil microbial population}

Microbial population were estimated by modified dilution spread plate method (Bey, 2001). Soils used for this study were collected at 40 DAP and 90 DAP. Soil dilutions were made using sterile saline solution $(0.85 \% \mathrm{NaCl})$ and vortex shaker was used for dispersion. Bacteria were cultured at three dilutions $\left(10^{-4}, 10^{-5}, 10^{-6}\right)$ with two replicates each on tryptic soy agar (TSA) media. Fungi were cultured at three dilutions $\left(10^{-3}, 10^{-4}\right.$ and $10^{-5}$ ) with two replicates each on corn meal agar (CMA) media containing streptomycin to limit bacterial growth. Plates containing 30-300 colonies were counted manually after 24 hours of incubation at $28^{\circ} \mathrm{C}$ for bacteria and after 7 days for fungi. The colony forming units (CFU) were calculated using the following formula:

$$
\mathrm{CFU} / \mathrm{g} \text { soil }=\frac{\text { number of colonies } \times \text { dilution factor }}{\text { volume of culture plate }(\mathrm{ml}) \times \text { dry weight of soil }(\mathrm{g})}
$$

\subsubsection{Estimation of arbuscular mycorrhizal (AM) fungi root colonization}

The degree of arbuscular mycorrhizal (AM) fungi colonization in the root samples was performed following a modified method by McGonigle et al. (1990). At the end of the Jalapeno growth period, the roots of each plants were carefully washed in a $2 \mathrm{~mm}$ sieve to remove all remaining soil particles. Twenty-five thin root fragments were removed from fresh root samples and submerged in micro centrifuge tubes containing $10 \%$ potassium 
hydroxide solution $(\mathrm{KOH})$. The tubes were placed in the oven at $70^{\circ} \mathrm{C}$ for 2 hours prior to rinsing with deionized (DI) water. Since the roots were clean and already white, bleaching was not conducted. The roots were then stained by adding a $0.5 \%$ Trypan blue/lactoglycerol solution in the tube and placed in the oven at $70^{\circ} \mathrm{C}$ for 30 minutes. Finally, the samples were thoroughly washed to remove any excess blue stain. Each set of 25 roots was placed horizontally on a microscopic slide containing a drop of lactoglycerol solution. Each root was examined under a compound microscope and recorded for colonization which was indicated by the visual presence of any three structures: hyphae, vesicles, or arbuscules. The percentage of AM fungi colonization was calculated by the following formula:

AM Fungi Root Colonization $(\%)=\frac{\text { Number of colonized roots }}{25} \times 100$

\subsubsection{Estimation of soil enzyme activity}

Soil enzyme activities for $\beta$-1-4-glucisidase (C), alkaline phosphatase (P), and $\beta$ $\mathrm{N}$-acetylglucosaminidase $(\mathrm{N})$ enzymes were conducted using the fluorescent model substrate 4-methylumbelliferone (MUF) assay (Sinsabaugh et al, 1997; Hoppe, 1993; Chrost and Kambeck, 1986). The soils collected at 90 DAP (during harvest) were used for this analysis. The substrates used for each of these enzyme assays were MUF- $\beta$-Dglucoside (MUF-C), MUF-phosphate (MUF-P), and MUF-N-acetyl- $\beta$-D-glucosaminide (MUF-N). Enzyme activity was determined from the difference between the amounts of fluorescent substrate liberating during incubation time $\left(\mathrm{t}_{\mathrm{f}}\right)$ from time zero $\left(\mathrm{t}_{0}\right)$. The amount of substrate liberated per gram of dry soil was determined by comparison to standard curves 
generated using known concentration of MUF substrates. Synergy HT Multi-Mode 96 well Plate reader was used to conduct this experiment.

\subsubsection{Statistical analysis}

Statistical analysis was performed using a statistical analysis system (SAS 9.4 and JMP pro 14). The differences between each treatment and the control as well as between treatments were evaluated using a one-way analysis of variance (ANOVA) followed by Tukey's honestly significant difference (HSD) post hoc test for the effect of biochars on plant shoot and root dry biomass, yield, AM fungi root colonization and soil enzyme activities. A two-way ANOVA for the effect of biochar and sampling time on plant height, number of leaves, SPAD values and soil microbial population was performed. Results were expressed as means and standard errors. Any differences between the mean values at $p<$ 0.05 were considered statistically significant.

\subsection{Results and Discussion}

\subsubsection{Effect of treatments on plant parameters}

The effect of different treatments on Capsicum annuum 'Jalapeno' plant growth and yield are presented in Figures 4.2 and 4.3, and Table 4.3. The interactive effect of treatment and sampling time was not significantly different for plant height, number of leaves and SPAD values (Table 4.2). A lack of significance in the interaction suggests the sampling time did not influence the effects of the treatments on the plant parameters and vice versa, although the treatments and sampling time separately were influential on the above-mentioned plant growth parameters. In some plants the biochar treatments resulted in a decrease in plant height, number of leaves and SPAD values compared to the control (T2) but the effect was not significant. 
Table 4. 2 The $p$ values for the main and interaction effect on treatment and sampling time for plant height, leaf number and SPAD values for Capsicum annuum 'Jalapeno' during the entire growing season.

\begin{tabular}{llll}
\hline Sources of Variation & $\begin{array}{l}\text { Plant Height } \\
(\mathrm{cm})\end{array}$ & $\begin{array}{l}\text { Number of } \\
\text { Leaves }\end{array}$ & $\begin{array}{l}\text { Leaf SPAD } \\
\text { Value }\end{array}$ \\
\hline Treatment & $0.0001^{*}$ & $0.0005^{*}$ & $0.0001^{*}$ \\
Sampling time & $0.0001^{*}$ & $0.0001^{*}$ & $0.001^{*}$ \\
Treatment $\times$ Sampling time & 0.0419 & 0.6322 & 0.608 \\
\hline
\end{tabular}

${ }^{*}=$ Significant at $p<0.05$.

The biochar treatments did not have any significant effect on the above ground (leaf, branch and shoot) biomass dry weight (g) and below ground (root) biomass dry weight (g) compared to the control (T2), however there was significant difference among the biochar treatments in their effects (Table 4.3). Plants that received treatment T6 (containing Brazilian pepper biochars made at $500^{\circ} \mathrm{C}$ ) had the highest shoot $(45 \%)$ and root $(43 \%)$ dry weight compared to the rest of the treatments. The effect from T6 was significantly higher than the plants receiving treatment T12 (containing cypress biochars at made $500^{\circ} \mathrm{C}$ ) but not from the control (T2). Some of the biochar treatments caused a reduction in shoot and root biomass dry weight but no significant difference from the control was observed. Particularly, plants that received the T12 resulted in the lowest amount of shoot and root biomass dry weight. There was an increase in the shoot to root ratios of the plants receiving biochar treatments compared to the control. 


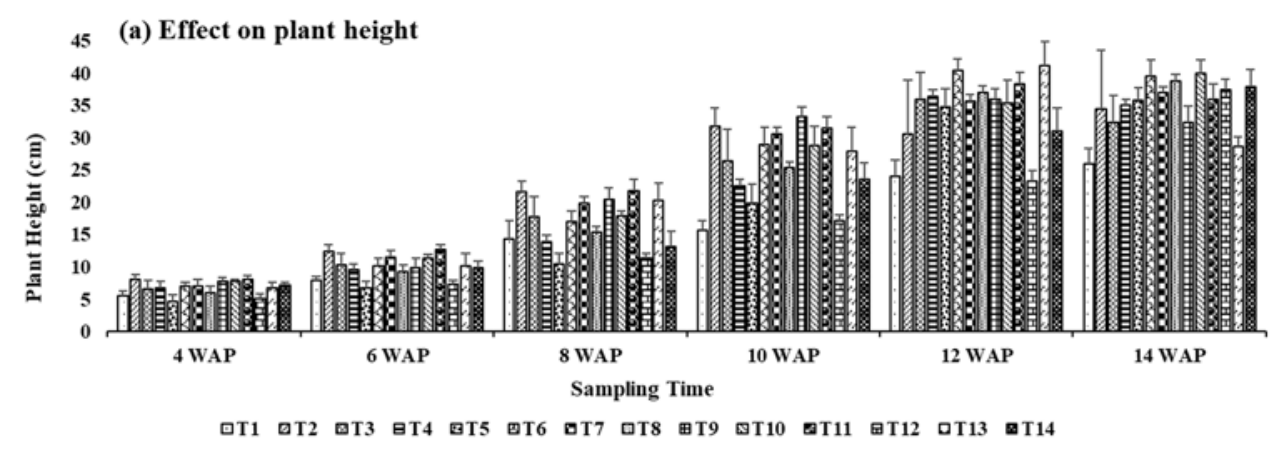

(b) Effect on number of leaves

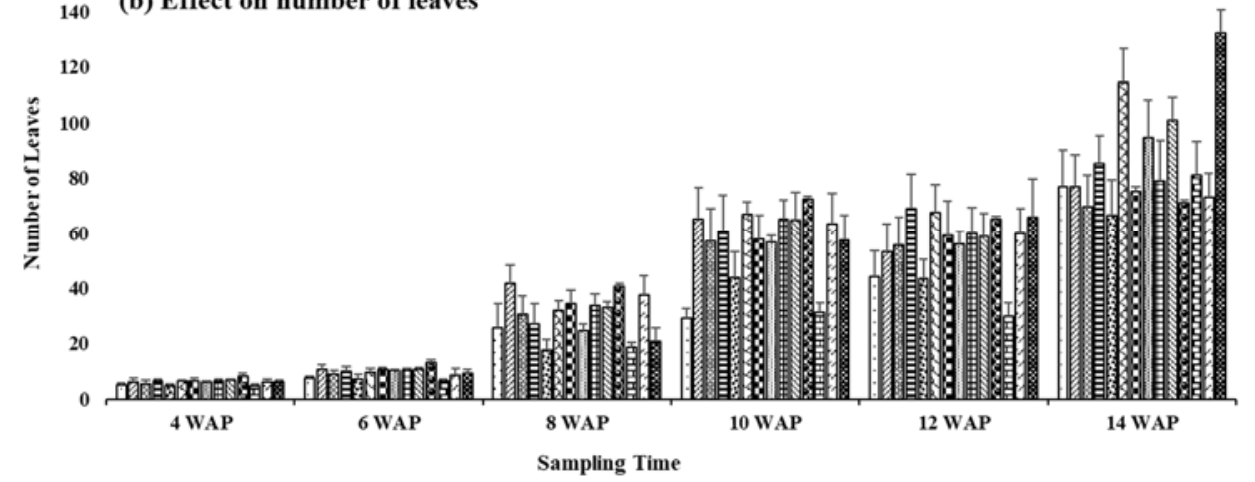

Figure 4. 2 Effect of different treatments on (a) plant height and (b) number of leaves throughout the growing season of Capsicum annuum 'Jalapeno'. Treatment abbreviations are the same as in Figure 4.1. Error bar represents standard error of mean values. WAP $=$ Weeks after planting.

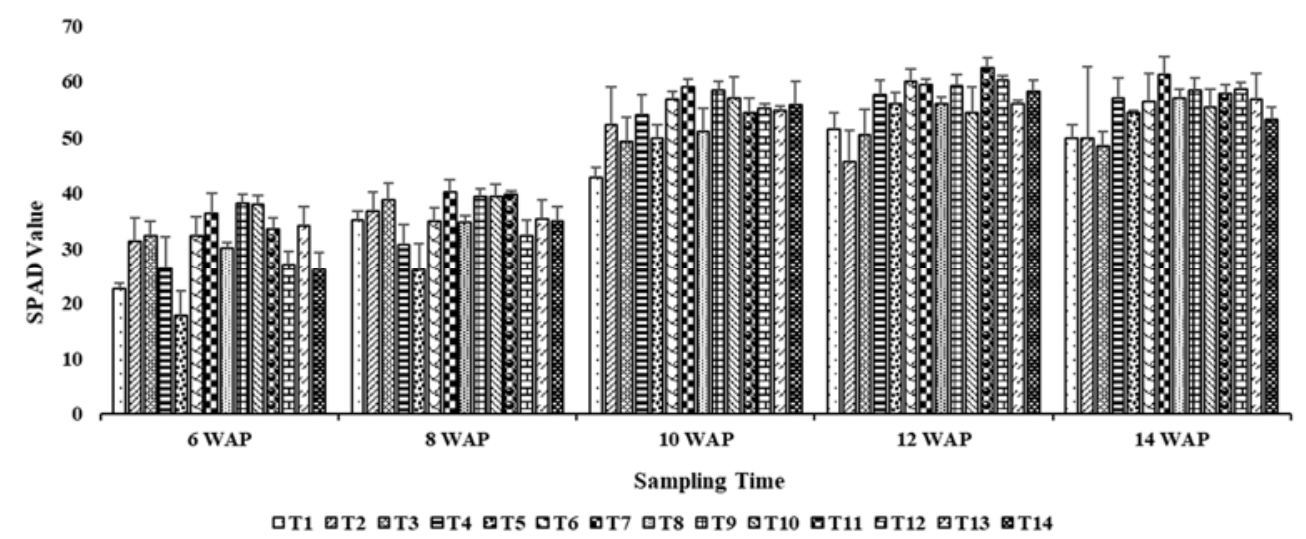

Figure 4. 3 Comparison of soil plant analysis development (SPAD) chlorophyll meter value of the leaves throughout the growing season of Capsicum annuum 'Jalapeno'. Treatment abbreviations are the same as in Figure 4.1. Error bar represents standard error of mean values. WAP = Weeks after planting. 
The variation among the biochar treatments significantly influenced the number and fresh weight (g) of Jalapeno fruits but the difference was not significant compared to the control. Plants that received treatments T3 (containing Australian pine derived biochar at $350^{\circ} \mathrm{C}$ ), T6 (containing Brazilian pepper derived biochar at $500^{\circ} \mathrm{C}$ ), T9 (containing loblolly pine derived biochar at $350^{\circ} \mathrm{C}$ ), and $\mathrm{T} 11$ (containing cypress derived biochar at $350^{\circ} \mathrm{C}$ ) produced $9 \%, 33 \%, 25 \%$, and $20 \%$, respectively, higher number of fruits than the control (not significant at $p<0.05$ ). Plants treated with T11 were found to have the maximum fresh weight of fruits which was almost double than the average weight of fruits from all the remaining treatments. The effect of $\mathrm{T} 11$ on fruit weight was significantly higher than the plants receiving T12 (containing cypress derived biochar at $500^{\circ} \mathrm{C}$ ) (Table 4.3) but not from the control (T2). Treatments T3 (containing Australian pine derived biochars at $350^{\circ} \mathrm{C}$ ), $\mathrm{T} 4$ (containing Australian pine derived biochars at $500^{\circ} \mathrm{C}$ ), T6 (containing Brazilian pepper derived biochar at $500^{\circ} \mathrm{C}$ ), T9 (containing loblolly pine derived biochar at $350^{\circ} \mathrm{C}$ ), T11 (cypress derived biochar at $350^{\circ} \mathrm{C}$ ) and $\mathrm{T} 14$ (pecan shell derived biochar at $500^{\circ} \mathrm{C}$ ) produced fruits that had fresh weights that were $18 \%, 19 \%, 38 \%$, $20 \%, 44 \%$ and $25 \%$, respectively, higher than that produced from plants receiving the control (T2), but not significant at $p<0.05$. Similar to shoot and root biomass dry weight, plants treated with T12 resulted in the lowest number and fresh weight of fruits. 
Table 4. 3 Effect of different treatments on plant leaf, branch, shoot and root dry weight, fruit number and fruit fresh weight.

\begin{tabular}{|c|c|c|c|c|c|c|c|}
\hline Treatment & $\begin{array}{c}\text { Leaf } \\
\text { Weight }(g)\end{array}$ & $\begin{array}{c}\text { Branch } \\
\text { Weight (g) }\end{array}$ & $\begin{array}{c}\text { Shoot } \\
\text { Weight (g) }\end{array}$ & $\begin{array}{c}\text { Root } \\
\text { Weight (g) }\end{array}$ & $\begin{array}{c}\text { Shoot to Root } \\
\text { Ratio }\end{array}$ & $\begin{array}{c}\text { Number of } \\
\text { Fruits }\end{array}$ & Fruit Weight (g) \\
\hline $\mathrm{T} 1$ & $1.736 \pm 0.28^{\mathrm{B}}$ & $1.55 \pm 0.23^{\mathrm{C}}$ & $3.29 \pm 0.48^{\mathrm{C}}$ & $1.12 \pm 0.22^{\mathrm{C}}$ & 3.17 & $1.33 \pm 0.29^{\mathrm{C}}$ & $10.96 \pm 2.21^{\mathrm{C}}$ \\
\hline $\mathrm{T} 2$ & $6.42 \pm 0.94^{\mathrm{A}}$ & $4.90 \pm 1.11^{\mathrm{AB}}$ & $12.06 \pm 2.11^{\mathrm{AB}}$ & $3.46 \pm 0.95^{\mathrm{A}}$ & 2.75 & $9.20 \pm 1.08^{\mathrm{AB}}$ & $71.76 \pm 13.17^{\mathrm{AB}}$ \\
\hline $\mathrm{T} 3$ & $4.33 \pm 1.17^{\mathrm{AB}}$ & $4.06 \pm 1.08^{\mathrm{ABC}}$ & $8.39 \pm 2.23^{\mathrm{ABC}}$ & $2.98 \pm 0.70^{\mathrm{ABC}}$ & 2.73 & $10.00 \pm 1.87^{\mathrm{AB}}$ & $84.98 \pm 15.20^{\mathrm{ABC}}$ \\
\hline $\mathrm{T} 4$ & $5.31 \pm 1.29^{\mathrm{A}}$ & $4.98 \pm 1.38^{\mathrm{A}}$ & $10.29 \pm 2.66^{\mathrm{ABC}}$ & $3.48 \pm 0.85^{\mathrm{A}}$ & 2.94 & $9.00 \pm 1.96^{\mathrm{AB}}$ & $85.23 \pm 11.84^{\mathrm{AB}}$ \\
\hline $\mathrm{T} 5$ & $4.00 \pm 0.71^{\mathrm{AB}}$ & $3.74 \pm 0.72^{\mathrm{ABC}}$ & $7.74 \pm 1.40^{\mathrm{ABC}}$ & $2.59 \pm 0.39^{\mathrm{ABC}}$ & 2.92 & $5.75 \pm 1.03^{\mathrm{ABC}}$ & $48.35 \pm 14.79^{\mathrm{ABC}}$ \\
\hline T6 & $7.26 \pm 0.73^{\mathrm{A}}$ & $6.63 \pm 0.69^{\mathrm{A}}$ & $13.90 \pm 1.34^{\mathrm{A}}$ & $4.71 \pm 0.39^{\mathrm{A}}$ & 2.94 & $12.25 \pm 1.70^{\mathrm{A}}$ & $98.66 \pm 8.28^{\mathrm{A}}$ \\
\hline $\mathrm{T} 7$ & $5.9 \pm 0.85^{\mathrm{AB}}$ & $5.13 \pm 0.86^{\mathrm{ABC}}$ & $11.03 \pm 1.71^{\mathrm{ABC}}$ & $3.74 \pm 0.61^{\mathrm{AB}}$ & 2.97 & $8.25 \pm 0.75^{\mathrm{ABC}}$ & $54.49 \pm 9.26^{\mathrm{ABC}}$ \\
\hline $\mathrm{T} 8$ & $4.76 \pm 0.73^{\mathrm{AB}}$ & $4.35 \pm 0.92^{\mathrm{ABC}}$ & $9.11 \pm 1.62^{\mathrm{ABC}}$ & $3.06 \pm 0.58^{\mathrm{ABC}}$ & 3.02 & $5.40 \pm 1.21^{\mathrm{ABC}}$ & $48.16 \pm 10.37^{\mathrm{ABC}}$ \\
\hline T9 & $6.20 \pm 0.75^{\mathrm{A}}$ & $6.04 \pm 0.73^{\mathrm{A}}$ & $12.24 \pm 1.48^{\mathrm{AB}}$ & $4.19 \pm 0.48^{\mathrm{A}}$ & 2.91 & $11.50 \pm 1.19^{\mathrm{AB}}$ & $85.57 \pm 16.00^{\mathrm{ABC}}$ \\
\hline $\mathrm{T} 10$ & $5.17 \pm 0.58^{\mathrm{AB}}$ & $4.87 \pm 0.97^{\mathrm{AB}}$ & $10.04 \pm 1.52^{\mathrm{ABC}}$ & $3.78 \pm 0.66^{\mathrm{A}}$ & 2.74 & $9.00 \pm 1.73^{\mathrm{AB}}$ & $71.82 \pm 15.50^{\mathrm{ABC}}$ \\
\hline $\mathrm{T} 11$ & $6.04 \pm 0.77^{\mathrm{A}}$ & $5.75 \pm 0.62^{\mathrm{A}}$ & $11.79 \pm 1.35^{\mathrm{AB}}$ & $4.21 \pm 0.42^{\mathrm{A}}$ & 2.78 & $11.00 \pm 1.34^{\mathrm{A}}$ & $103.30 \pm 12.84^{\mathrm{A}}$ \\
\hline $\mathrm{T} 12$ & $2.29 \pm 0.27^{\mathrm{B}}$ & $1.92 \pm 0.32^{\mathrm{BC}}$ & $4.21 \pm 0.58^{\mathrm{BC}}$ & $1.44 \pm 0.23^{\mathrm{BC}}$ & 2.99 & $2.80 \pm 0.58^{\mathrm{BC}}$ & $22.47 \pm 6.05^{\mathrm{BC}}$ \\
\hline $\mathrm{T} 13$ & $5.14 \pm 1.04^{\mathrm{AB}}$ & $5.28 \pm 1.20^{\mathrm{ABC}}$ & $10.42 \pm 2.16^{\mathrm{ABC}}$ & $3.79 \pm 0.91^{\mathrm{AB}}$ & 2.85 & $6.40 \pm 1.60^{\mathrm{ABC}}$ & $65.74 \pm 16.82^{\mathrm{ABC}}$ \\
\hline $\mathrm{T} 14$ & $4.35 \pm 0.83^{\mathrm{AB}}$ & $3.67 \pm 0.73^{\mathrm{ABC}}$ & $8.03 \pm 1.54^{\mathrm{ABC}}$ & $2.91 \pm 0.65^{\mathrm{ABC}}$ & 2.90 & $8.40 \pm 1.33^{\mathrm{AB}}$ & $89.63 \pm 13.35^{\mathrm{AB}}$ \\
\hline
\end{tabular}

Treatment abbreviations are the same as in Figure 4.1. Values are expressed as mean \pm standard error. Means within a column followed by the same letters are not significantly different at $p<0.05$. 
Biochar can have positive, negative, and even no effect on plant growth (Gaskin et al., 2010; Major et ai., 2010; Dunlop et al., 2015; Vaughn et al., 2015; Guo et al., 2018). The effect of biochar on plant growth depend on several factors including type of biochar, applicate rate, soil properties and plant species (Alburquerque et al., 2014, Yu, et al. 2020). In this study no significant effects of the biochar treatments were observed on plant growth and yield compared to the control. A study conducted by Tammeorg et al. (2014) using spruce (Picea abies (L.) H. Karst.) derived biochar made at $550-600^{\circ} \mathrm{C}$ also found no significant effects of biochar on the growth and yield of wheat. Similarly, de Melo Carvalho et al. (2013) observed no distinct effect of biochar made from Eucalyptus sp. at $400-500^{\circ} \mathrm{C}$ on rice yield. Generally, improved plant growth and yield have been attributed to improved structure, $\mathrm{pH}$ conditions, water, and nutrient availability in soil due to biochar addition (Lehman and Joseph, 2009; Sun et al., 2014, Akca and Namli, 2015). Even though soil nutrient levels were not measured in this study the properties of biochar including pore structure, specific surface area (SSA), and cation exchange capacity (CEC) can contribute towards the retention and slow release of nutrients to soil that can be conducive to the observed increase in shoot and root biomass dry weight and fruit yield of the Jalapeno pepper plants (Table 4.1) (Chan et al., 2008; Blackwell et al., 2010; Ding et al., 2016). Additionally, biochar can serve as a fertilizer by supplying certain macro- and micronutrients to soil which may be present in the ash fraction during the production of biochar (Altland and Locke, 2013; Caroline et al., 2016; Liu et al., 2019). Biochar can also influence the bacterial diversity which can enhance nitrogen mineralization, thus improving plant nutrition and growth (Weidner et al., 2015; Caroline et al., 2016). Lower plant biomass weight and yield can be attributed to the higher volatile matter (VM) content 
(> 23\%), C/N ratio and pH of the biochar (Deenik et al., 2010; Lenze and Ippolito, 2012; Gravel et al., 2013; Velez et al., 2018; Liu et al., 2019). High C/N ratios can cause higher nitrogen immobilization and result in decreased nitrogen availability and uptake by plants. Availability of macro- and micro- nutrients needed for plant growth can be reduced by the high $\mathrm{pH}$ of biochar $(\mathrm{pH}>8)$. Toxic substances (e.g., phenols, furans, and oligosaccharides) can be present in biochars, specially biochar made from woody feedstock, and this can severely affect the plant growth (Gundale and DeLuca, 2007; Deenik et al., 2010). The high $\mathrm{VM}$ content, $\mathrm{C} / \mathrm{N}$ ratio and $\mathrm{pH}$ observed in some of the biochars may have been responsible for the reduced growth and yield in plants receiving those treatments (Table 4.1). This study found that the biochars made from Brazilian pepper at $500^{\circ} \mathrm{C}$ performed best in affecting the overall growth and yield of Jalapeno pepper plants.

\subsubsection{Enumeration of soil microbial population}

The estimates of soil microbial population (colonies) based on dilution spread plate counts are presented in Figure 4.4. The effect of treatment, sampling time, and the interaction between treatment and sampling time on bacteria and fungi population in soil was significant $(p<0.05)$ (Table 4.4). The treatments containing biochars made from coconut husk (T7 and T8) resulted in the highest number of bacteria colonies in soils collected at 40 days after planting (DAP) Jalapeno. This was 9.5\% (significant at $p<0.05$ ) higher than the number of bacteria colonies observed in the control (T2). These treatments also resulted in $19 \%, 11 \%, 13 \%, 15 \%$ and $8 \%$, respectively, significantly higher bacteria colonies than the treatments containing Australian pine biochars (T3 and T4), Brazilian pepper biochars (T5 and T6), loblolly pine biochars (T9 and T10), cypress biochars (T11 and T12), and pecan shell biochars (T13 and T14). 
Table 4. 4 The $p$ values for the main and interaction effect on treatment and sampling time for bacterial and fungal population in soil.

\begin{tabular}{llc}
\hline Sources of Variation & Bacteria & Fungi \\
\hline Treatment & $0.0001^{*}$ & $0.0001^{*}$ \\
Sampling time & $0.0001^{*}$ & $0.0001^{*}$ \\
Treatment $\times$ Sampling time & $0.0001^{*}$ & $0.0001^{*}$ \\
\hline
\end{tabular}

${ }^{*}=$ Significant at $p 0.05$.

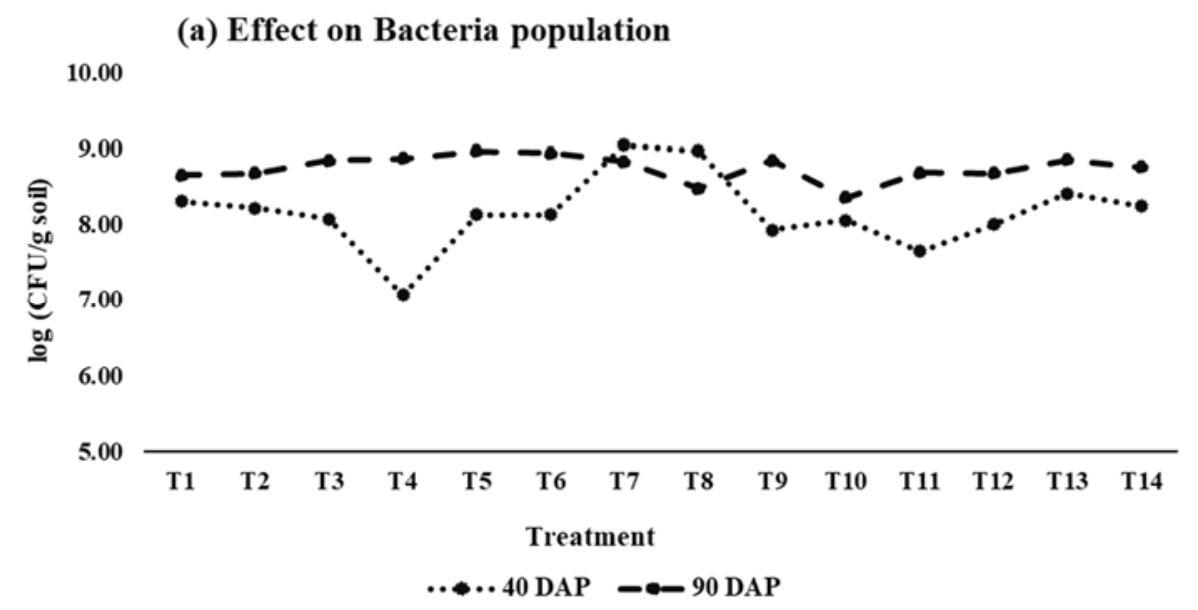

(b) Effect on Fungi population

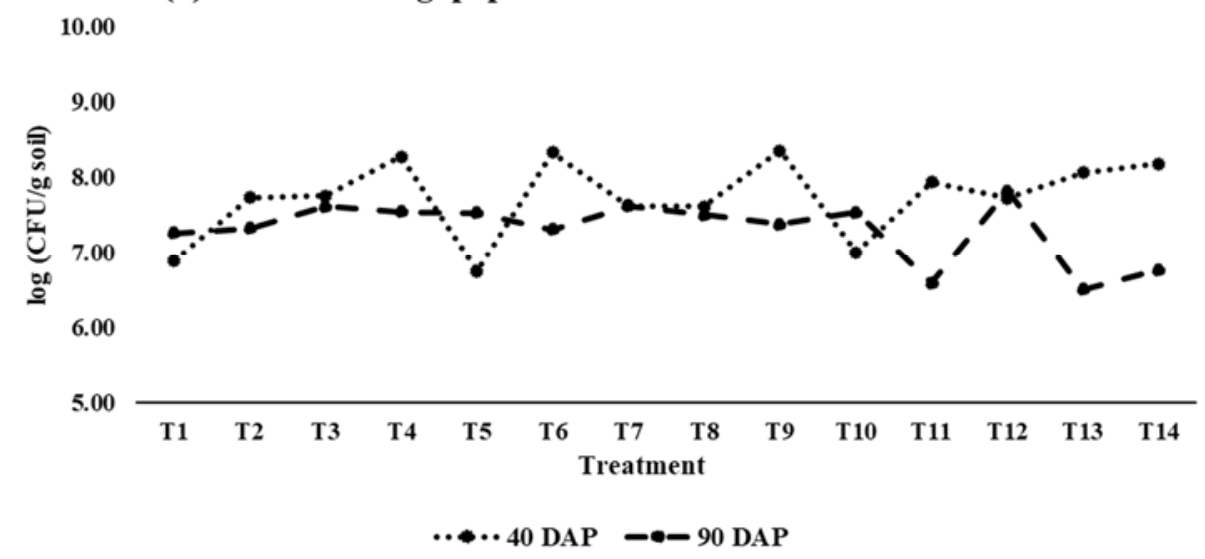

Figure 4. 4 Effect of different treatments on (a) bacteria and (b) fungi population in soil 40 days and 90 days after plating Capsicum annuum 'Jalapeno' based on dilution plate counts. Treatment abbreviations are the same as in Figure 4.1. DAP = Days after planting.

Soils containing treatments from Australian pine biochars (T3 and T4) resulted in the lowest number of bacteria colonies, particularly treatment T4 (biochars made from Australian pine at $\left.500^{\circ} \mathrm{C}\right)$ had the significantly lowest (14\%) compared to control (T2) at 
40 DAP soils. There was an overall average $10 \%$ increase $(p<0.05)$ in the bacteria population in soils collected at 90 DAP from soils at 40 DAP for most of the treatments including the control. However, coconut husk biochar treatments (T7 and T8) resulted in a $3.8 \%$ reduction (not significant at $p<0.05$ ) in bacteria population (Figure 4.4) at 90 DAP soils than the 40 DAP soils, possibly resulting from the toxicity of the comparatively high volatile matter (VM) content of these biochars (Table 4.1). Compared to the control (T2), soils treated with Australian pine biochars (T3 and T4), Brazilian pepper biochars (T5 and T6), pecan shell biochars (T13 and $\mathrm{T} 14)$, coconut husk biochars at $350^{\circ} \mathrm{C}(\mathrm{T} 7)$, and cypress biochars at $500^{\circ} \mathrm{C}(\mathrm{T} 12)$ resulted in a slightly higher (an average $2 \%$ ) bacteria colonies in 90 DAP soils. Treatment T10 (containing loblolly pine biochars made at $350^{\circ} \mathrm{C}$ ) had the lowest number of bacteria colonies at 90 DAP soils, which was significantly lower (7\%) than soils treated with $\mathrm{T} 5$ (containing Brazilian pepper biochars made at $350^{\circ} \mathrm{C}$ ) but the difference was not significant compared to the control (T2).

Similar to bacteria population, the fungi population was also significantly influenced by the effect of treatment, sampling time, and the interaction between treatment and sampling time (Table 4.4). The treatments T4 (containing Australian pine biochars made at $500^{\circ} \mathrm{C}$ ), $\mathrm{T} 6$ (containing Brazilian pepper biochars made at $500^{\circ} \mathrm{C}$ ), $\mathrm{T} 9$ (containing loblolly pine biochars made at $350^{\circ} \mathrm{C}$ ) and $\mathrm{T} 14$ (containing pecan shell biochars made at $500^{\circ} \mathrm{C}$ ) resulted in significantly higher number of fungi colonies in soils collected at 40 DAP when compared to the control (T2), which was $7 \%, 8 \%, 8 \%$, and $6 \%$ higher, respectively. Treatment $\mathrm{T} 9$ also had a $8 \%, 24 \%, 10 \%, 20 \%$, and $7 \%$, respectively, significantly higher fungi colonies compared to treatments containing Australian pine biochars made at $350^{\circ} \mathrm{C}(\mathrm{T} 3)$, Brazilian pepper biochars made at $350^{\circ} \mathrm{C}(\mathrm{T} 5)$, coconut husk 
biochars made at $350^{\circ} \mathrm{C}$ and $500^{\circ} \mathrm{C}(\mathrm{T} 7$ and $\mathrm{T} 8)$, loblolly pine biochars made at $500^{\circ} \mathrm{C}$ (T10), and cypress biochar made at $350^{\circ} \mathrm{C}$ and $500^{\circ} \mathrm{C}$ (T11 and T12). Among the different biochar treatments T5 resulted in the lowest number of fungi colonies at 40 DAP soils, which was significantly lower (15\%) than the control and the remaining biochar treatments, except T10 (containing loblolly pine biochars made at $500^{\circ} \mathrm{C}$ ). There was an overall average $8 \%$ decrease $(p<0.05)$ in the fungi population in soils collected at 90 DAP from soils at 40 DAP for most of the treatments including control, except for T5 and T10 treated soils, where $12 \%$ and $8 \%$ increase were observed, respectively. The average pore size of the Brazilian pepper derived biochars in treatment T5 and the total pore volume (TPV) of loblolly pine derived biochar in treatment T10 may have influenced higher fungi population in soil. The soils treated with $\mathrm{T} 12$ (containing cypress biochar made at $500^{\circ} \mathrm{C}$ ) had a significantly higher (7\%) fungi population compared to the control (T2) at 90 DAP soils. Considering the rest of the biochar treatments, T12 (treatments containing biochars made from cypress at $500^{\circ} \mathrm{C}$ ) resulted in a $5 \%, 6 \%$ and $18 \%$, respectively, significantly higher fungi population than $\mathrm{T} 5$ and $\mathrm{T} 6$ (treatments containing biochars made from Brazilian pepper at $350^{\circ} \mathrm{C}$ and $500^{\circ} \mathrm{C}$ ), $\mathrm{T} 9$ (treatment containing loblolly derived biochars at $350^{\circ} \mathrm{C}$ ), and $\mathrm{T} 13$ and $\mathrm{T} 14$ (treatments containing biochars made from pecan shell at $350^{\circ} \mathrm{C}$ and $500^{\circ} \mathrm{C}$ ) in $90 \mathrm{DAP}$ soils. The high specific surface area (SSA) and likely positive effect of the VM content of cypress biochar at $500^{\circ} \mathrm{C}(\mathrm{T} 12)$ may have played a role in the observed higher fungi population. Soils containing treatments from pecan shell biochars, particularly $\mathrm{T} 13$ (containing pecan shell biochars made at $350^{\circ} \mathrm{C}$ ) resulted in the lowest number of fungi colonies which was significantly lower (11\%) than the control (T2) at 90 
DAP soils possibly resulting from the low TPV of these biochars that could have exposed more fungi to predators.

The physicochemical properties of biochar, as well as the biochar-induced changes in soil physicochemical properties can alter the activities of soil microorganisms. In this study it was observed that there was an increase in bacteria population whereas a decrease in fungi population by the effects of the different biochar treatments. A study conducted by Jones et al. (2012) using biochars made from European ash tree (Fraxinus excelsior L.), European beech tree (Fagus sylvatica L.) and European oak tree (Quercus robur L.) at $450^{\circ} \mathrm{C}$ also observed an increase in bacterial growth with an inhibition in fungal growth. Similar results were also found by Chen et al. (2013) using biochars made from wheat (Triticum aestivum) at $350-550^{\circ} \mathrm{C}$. Several factors can contribute to the change in microbial population in soil caused by the effect of biochar. The porous structure of biochar can potentially provide a habitat for bacteria and fungi as well as protection from predators (Ezawa et al., 2002; Saito and Marumoto, 2002; Warnock et al., 2007; Thies and Rillig, 2009). The relatively larger sized fungi can be restricted to live on the surface and in the macro pores of biochars, whereas relatively smaller sized bacteria can live inside the micro pores. This may result in higher chances of protection for the bacteria than the fungi from predators, especially on the smaller pores. The biochar itself or biochar modified soil can sorb toxins thus lowering the toxicity to microbes and enhancing microbial population in soil (Kasozi et al., 2010; Chen et al., 2012). The addition of biochar increases the organic carbon content in soil which improves the retention and accessibility of nutrients to soil microbes (Lehmann et al., 2011). The organic compounds (VM content) present in biochar during production may suppress some members of the microbial community and promote 
others (Kolton et al., 2011; Lehmann et al., 2011). The microbial growth can be influenced by the $\mathrm{pH}$ of the biochar or the biochar modified soil (Marstorp et al., 2000; Chen et al. 2013; Graber et al., 2014). A neutral or slightly alkaline condition is favorable for bacterial growth but reduces fungal growth (Rousk et al., 2009). Another major component that can affect microbial population is the ash content of the biochars (Lehmann et al., 2011). As previously mentioned, the ash content includes macro- and micro- nutrients which can be available for microbial uptake. In this study the variable levels of VM content, ash content, $\mathrm{pH}$ and pore structure of the biochars influenced changes in bacteria and fungi population, where higher $\mathrm{pH}$ and pore structure favored higher bacteria population over fungi population (Table 4.1).

\subsubsection{Estimation of root colonization by arbuscular mycorrhizal (AM) fungi}

The biochar treatments significantly affected the arbuscular mycorrhizal (AM) fungi colonization in the Jalapeno plant roots (Table 4.5). Plant roots that received treatments containing coconut husk biochars (T7 and T8), loblolly pine biochar (T9 and T10), cypress biochars (T11 and T12), and pecan shell biochars (T13 and T14) resulted in $159 \%, 169 \%, 203 \%$, and 179\%, respectively, significantly $(p<0.05)$ higher root colonization by AM fungi than the control (T2). The control (T2) also had the lowest percentage of root colonization by AM fungi. It can be noted that among the different biochar treatments, the ones containing Australian pine derived biochars had the lowest percentage of root colonization, which was significantly lower than the remaining biochar treatments, except for treatments containing Brazilian pepper derived biochars. 
Table 4. 5 Effect of different treatments on arbuscular mycorrhizal (AM) fungi root colonization during Capsicum annuum 'Jalapeno' production.

\begin{tabular}{cc}
\hline Treatment & $\begin{array}{c}\text { AM Fungi Root } \\
\text { Colonization (\%) }\end{array}$ \\
\hline T1 & $34.0 \pm 1.15^{\mathrm{BCD}}$ \\
$\mathrm{T} 2$ & $21.0 \pm 5.26^{\mathrm{D}}$ \\
$\mathrm{T} 3$ & $29.0 \pm 3.42^{\mathrm{CD}}$ \\
$\mathrm{T} 4$ & $28.8 \pm 3.88^{\mathrm{D}}$ \\
$\mathrm{T} 5$ & $47.2 \pm 6.74^{\mathrm{ABCD}}$ \\
$\mathrm{T} 6$ & $44.8 \pm 1.96^{\mathrm{ABCD}}$ \\
$\mathrm{T} 7$ & $53.6 \pm 6.25^{\mathrm{ABC}}$ \\
$\mathrm{T} 8$ & $55.2 \pm 3.20^{\mathrm{AB}}$ \\
$\mathrm{T} 9$ & $57.6 \pm 3.71^{\mathrm{AB}}$ \\
$\mathrm{T} 10$ & $55.2 \pm 3.44^{\mathrm{AB}}$ \\
$\mathrm{T} 11$ & $61.6 \pm 4.31^{\mathrm{A}}$ \\
$\mathrm{T} 12$ & $65.6 \pm 2.04^{\mathrm{A}}$ \\
$\mathrm{T} 13$ & $59.2 \pm 2.65^{\mathrm{AB}}$ \\
$\mathrm{T} 14$ & $58.0 \pm 4.76^{\mathrm{ABC}}$ \\
\hline
\end{tabular}

Treatment abbreviations are the same as in Figure 4.1. Numbers are expressed as mean \pm standard error. Means within a column followed by a different letter are significantly different at $p<0.05$.

There are several ways biochar could affect AM fungi colonization in plant roots including protection in the biochar pores from grazers, change in soil physicochemical properties and nutrient availability, change in soil microbial population that support AM fungi colonization, sorption of signaling compounds or detoxification of allelochemicals that inhibit AM fungi colonization (Warnock et al. 2007; Elmer and Pignatello, 2011). Although the present study was not designed to explain the relative importance of the above-mentioned mechanisms, the study shows that biochar may have caused an increase in AM colonization through the sorption behavior (CEC and SSA) and pore structure of the biochars and by enhancing soil microbes that favor AM colonization. 


\subsubsection{Estimation of soil enzyme activity}

Significant changes in enzyme activities for alkaline phosphatase and $\beta-\mathrm{N}$ acetylglucosaminidase enzymes were observed in soils by the different biochar treatments whereas there was no significant influence in the $\beta$-1-4-glucisidase enzyme activity (Figure 4.5 and Table 4.6). Soils that received treatment T11 (containing cypress biochars made at $350^{\circ} \mathrm{C}$ ) showed the highest (3.5 times) alkaline phosphatase enzyme activity compared to the control (T2) (significant at $p<0.05$ ). Soils treated with T13 (containing pecan shell biochars made at $350^{\circ} \mathrm{C}$ ) resulted in the lowest alkaline phosphatase enzyme activity, which was significantly lower (98\%) from the soils that received biochar treatment T11 ( $p$ $<0.05$ ) but the difference was not significant compared to the control (T2). The effect of treatment T6 (containing Brazilian pepper biochars made at $500^{\circ} \mathrm{C}$ ) on $\beta-\mathrm{N}$ acetylglucosaminidase enzyme activity in soils was 19 times significantly higher compared to the control (T2). A relatively low activity was observed for $\beta$-1-4-glucisidase enzyme and $\beta$-N-acetylglucosaminidase enzyme whereas higher activity for alkaline phosphatase was found in soils treated with different biochars.

Table 4. 6 The $p$ values for the effect of different treatments on the $\beta$-1-4-glucisidase (for carbon), $\beta$-N-acetylglucosaminidase (for nitrogen), and alkaline phosphatase (for phosphorus) enzyme activities in soil.

\begin{tabular}{llll}
\hline $\begin{array}{l}\text { Sources of } \\
\text { Variation }\end{array}$ & $\beta-1-4$-glucisidase & $\begin{array}{l}\beta-\mathrm{N}- \\
\text { acetylglucosaminidase }\end{array}$ & $\begin{array}{l}\text { Alkaline } \\
\text { phosphatase }\end{array}$ \\
\hline Treatment & 0.5845 & $0.0099^{*}$ & $0.0001^{*}$ \\
\hline${ }^{*}=$ Significant at $p<0.05$. & &
\end{tabular}

A Number of factors influence the effect of biochar on soil enzyme activity. Changes in nutrient availability and microbial population by biochar addition could affect soil enzyme activities (Waldrop et al., 2000; Marschner et al., 2003). As a huge portion of 
carbon is present in a stable form in biochar it may not act as a stimulant to enzyme activity in soil, therefore, comparatively lower $\beta-1-4$-glucisidase activity can be observed by different biochar applications (Wu et al., 2013). Soil enzymes and the substrates can become sorbed to biochar particles (CEC, SSA and the pore structures of the biochars) and reduce or even inhibit enzyme activity in soil (Bailey et al. 2011; Lammirato et al., 2011).

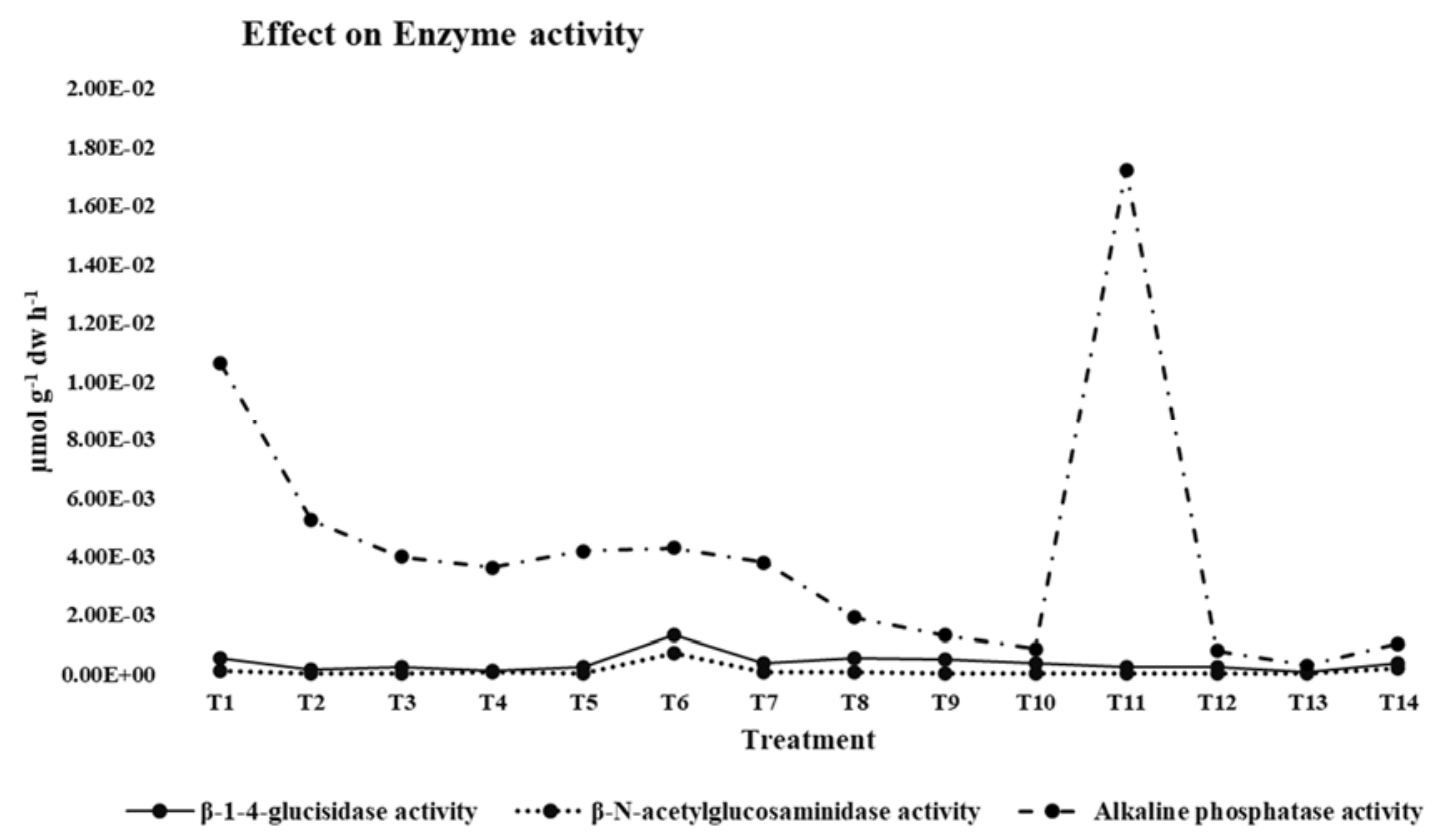

Figure 4. 5 Effect of different treatments on $\beta$-1-4-glucisidase, $\beta$-N-acetylglucosaminidase, and alkaline phosphatase enzyme activities in soil using the fluorescent model substrate 4-methylumbelliferone (MUF) assay. Treatment abbreviations are the same as in Figure 4.1.

Phosphatase enzyme activity is $\mathrm{pH}$ dependent and the high $\mathrm{pH}$ of biochars can influence the higher alkaline phosphatase activity in soil (Acosta-Martínez and Tabatabai, 2000). In this study the relatively higher phosphatase activity can be attributed to the higher $\mathrm{pH}$ of the biochars (Table 4.1). The relatively low activity observed for $\beta$-1-4-glucisidase enzyme and $\beta$-N-acetylglucosaminidase enzyme may have resulted for the biochar SSA and pore structure that caused inhibition of enzyme activity through sorption of the enzymes or even the substates to biochars. The comparatively lower SSA and TPV of cypress biochars made 
at $350^{\circ} \mathrm{C}$ can be considered responsible for the higher activity observed in soil alkaline phosphatase enzyme (Table 4.1). On the other hand, the relatively lower CEC observed in Brazilian pepper biochars made at $500^{\circ} \mathrm{C}$ were conducive for higher $\beta-\mathrm{N}$ acetylglucosaminidase enzyme activity in soil (Table 4.1). Biochars made from Brazilian pepper and cypress also enhanced the bacteria population in soil which may have indirectly influenced the higher enzyme activities in soils treated with these biochars.

\subsection{Conclusion}

This study found that the biochars did significantly affect the soil bacteria and fungi population, AM fungi root colonization and soil enzyme activities but no significant effect on the Jalapeno pepper growth and yield was observed. As potted plant growth cycles are relatively short, this might have been a limiting factor for adequately investigating the effects of biochars on Jalapeno. Applying this study on a field scale and measuring soil properties will allow for better evaluation of the effects of the biochars on plant growth. The results suggest that the sorption behavior (CEC and SSA), pore structure (TPV and pore size) of the biochars played important role in affecting microbial population in soil along with the possible indirect effects from the ash and VM content of the biochars. The enzyme activities in soil were also influenced by sorption behavior, pore structure and ash content of the biochars as well as potential effects from enhanced bacteria population in soil. The characteristics of biochars vary profoundly depending on the type of feedstock and pyrolysis temperature which in turn greatly influence the biochar application outcomes. Therefore, it is important to carefully select feedstocks and pyrolysis process to produce biochars in order to meet specific goals. In this study the type of feedstocks had a 
greater influence on the biochar performance than the selected production temperatures.

\section{CHAPTER 5 SUMMARY AND CONCLUSION}

The application of biochars in agricultural settings is a key to sequestering carbon along with improving soil quality. The properties of biochars and their effectiveness in various applications vary widely because of the type of feedstocks and production process. Biochar characterization is necessary in determining the behavior of biochars, therefore, is crucial in developing biochars with specific characteristics to meet specific goals. The type of soil, plants and climatic conditions further influence the effectiveness of biochars. More research is needed for better understanding these interactions to select appropriate biochars to successfully meet application objectives. In this study, Australian pine and Brazilian pepper (plant species invasive to South Florida) along with coconut husk and pecan shell (agricultural residues) were included as potential feedstocks for biochar production as a means to better manage invasive species and wastes. Results from this study showed that increase in pyrolysis temperature increased the aromaticity, ash content, $\mathrm{pH}$, specific surface area and pore volume and decreased the moisture and volatile matter content, cation exchange capacity and the average pore size of the biochars. In this study the aromaticity, surface area, pore structure and cation exchange capacity of the biochars were conducive in their ability to remove pesticide and also enhance microbial population in soil. The biochar made from coconut husk and pecan shell performed the best for controlling the sorption of atrazine in soil. Among the different feedstocks the biochars made from Brazilian pepper influenced overall growth and yield of Jalapeno pepper plants and the fungi population in soil. Australian pine derived biochars also enhanced pepper yield and soil fungi population. Similar to pesticide retention, coconut husk derived biochars resulted 
in higher root colonization by arbuscular mycorrhizal fungi. The results from this study demonstrate that the use of the invasive plant species- Australian pine and Brazilian pepper, and the agricultural residues-coconut husk and pecan shell as feedstocks for biochar production and subsequent application will provide a cost-effective and eco-friendly approach in agricultural settings. More research need be conducted to explore how these biochars will affect other agricultural crops grown locally and elsewhere, and perhaps in different agroclimatic regions to achieve both local and global benefits. 


\section{REFERENCES}

Acosta-Martinez, V., \& Tabatabai, M. A. (2000). Enzyme activities in a limed agricultural soil. Biology and Fertility of soils, 31(1), 85-91.

Agency for Toxic Substances and Disease Registry (ATSDR). 2003. Public health statement atrazine.

Agudo, A., Cabrera, L., Amiano, P., Ardanaz, E., Barricarte, A., Berenguer, T., ... \& Martínez, C. (2007). Fruit and vegetable intakes, dietary antioxidant nutrients, and total mortality in Spanish adults: findings from the Spanish cohort of the European Prospective Investigation into Cancer and Nutrition (EPIC-Spain). The American journal of clinical nutrition, 85(6), 1634-1642.

Ahmad, M., Lee, S. S., Dou, X., Mohan, D., Sung, J. K., Yang, J. E., \& Ok, Y. S. (2012). Effects of pyrolysis temperature on soybean stover-and peanut shell-derived biochar properties and TCE adsorption in water. Bioresource technology, 118, 536-544.

Ahmad, M., Rajapaksha, A. U., Lim, J. E., Zhang, M., Bolan, N., Mohan, D., \& Ok, Y. S. (2014). Biochar as a sorbent for contaminant management in soil and water: a review. Chemosphere, 99, 19-33.

Akça, M. O., \& Namli, A. (2015). Effects of poultry litter biochar on soil enzyme activities and tomato, pepper and lettuce plants growth. Eurasian Journal of Soil Science, 4(3), 161.

Alburquerque, J. A., Calero, J. M., Barrón, V., Torrent, J., del Campillo, M. C., Gallardo, A., \& Villar, R. (2014). Effects of biochars produced from different feedstocks on soil properties and sunflower growth. Journal of Plant Nutrition and Soil Science, 177(1), 1625.

Altland, J. E., \& Locke, J. C. (2013). Gasified rice hull biochar is a source of phosphorus and potassium for container-grown plants. Journal of Environmental Horticulture, 31(3), 138-144.

Ameloot, N., De Neve, S., Jegajeevagan, K., Yildiz, G., Buchan, D., Funkuin, Y. N., ... \& Sleutel, S. (2013). Short-term CO2 and N2O emissions and microbial properties of biochar amended sandy loam soils. Soil Biology and Biochemistry, 57, 401-410.

Antal, M. J., \& Grønli, M. (2003). The art, science, and technology of charcoal production. Industrial \& Engineering Chemistry Research, 42(8), 1619-1640.

Arbuckle, T. E., Lin, Z., \& Mery, L. S. (2001). An exploratory analysis of the effect of pesticide exposure on the risk of spontaneous abortion in an Ontario farm population. Environmental health perspectives, 109(8), 851-857.

ASTM International. (2007). Standard Test Method for Chemical Analysis of Wood Charcoal. ASTM. D1762-84. 2007.

Atwood, D., \& Paisley-Jones, C. (2017). Pesticides industry sales and usage: 2008-2012 market estimates. US Environmental Protection Agency, Washington, DC, 20460. 
Awad, Y. M., Blagodatskaya, E., Ok, Y. S., \& Kuzyakov, Y. (2012). Effects of polyacrylamide, biopolymer, and biochar on decomposition of soil organic matter and plant residues as determined by ${ }^{14} \mathrm{C}$ and enzyme activities. European Journal of Soil Biology, 48, $1-10$.

Bailey, V. L., Fansler, S. J., Smith, J. L., \& Bolton Jr, H. (2011). Reconciling apparent variability in effects of biochar amendment on soil enzyme activities by assay optimization. Soil Biology and Biochemistry, 43(2), 296-301.

Barbash, J. E., Thelin, G. P., Kolpin, D. W., \& Gilliom, R. J. (2001). Major herbicides in ground water. Journal of Environmental Quality, 30(3), 831-845.

Barco-Bonilla, N., Romero-González, R., Plaza-Bolaños, P., Vidal, J. L. M., \& Frenich, A. G. (2013). Systematic study of the contamination of wastewater treatment plant effluents by organic priority compounds in Almeria province (SE Spain). Science of the total environment, 447, 381-389.

Batista, E. M., Shultz, J., Matos, T. T., Fornari, M. R., Ferreira, T. M., Szpoganicz, B., \& Mangrich, A. S. (2018). Effect of surface and porosity of biochar on water holding capacity aiming indirectly at preservation of the Amazon biome. Scientific reports, 8(1), 1-9.

Baumert, K. A. (2005). Navigating the Numbers: Greenhouse Gas Data and International Climate Policy, Washington DC. http://www.wri.org/publication/navigating-the-numbers.

Bey, R., (2001). Microbiology Laboratory Manual. Wadsworth Group, Thomson Learning Inc. USA.

Bhandari, A., Novak, J. T., \& Berry, D. F. (1996). Binding of 4-monochlorophenol to soil. Environmental science \& Johnson, R., Crafton, R. E., \& Upton, H. F. (2017). Invasive species: major laws and the role of selected federal agencies. Washington, DC: Congressional Research Service. Johnson, R., Crafton, R. E., \& Upton, H. F. (2017). Invasive species: major laws and the role of selected federal agencies. Washington, DC: Congressional Research Service technology, 30(7), 23052311.

Birk, J. J., Steiner, C., Teixiera, W. C., Zech, W., \& Glaser, B. (2009). Microbial response to charcoal amendments and fertilization of a highly weathered tropical soil. In Amazonian dark earths: Wim Sombroek's vision (pp. 309-324). Springer, Dordrecht.

Blackwell, P., Riethmuller, G., \& Collins, M. (2009). Biochar application to soil. Biochar for environmental management: science and technology, 1, 207-226.

Blackwell, P., Krull, E., Butler, G., Herbert, A., \& Solaiman, Z. (2010). Effect of banded biochar on dryland wheat production and fertiliser use in south-western Australia: an agronomic and economic perspective. Soil Research, 48(7), 531-545.

Borchard, N., Siemens, J., Ladd, B., Möller, A., \& Amelung, W. (2014). Application of biochars to sandy and silty soil failed to increase maize yield under common agricultural practice. Soil and Tillage Research, 144, 184-194. 
Brewer, C. E., Schmidt-Rohr, K., Satrio, J. A., \& Brown, R. C. (2009). Characterization of biochar from fast pyrolysis and gasification systems. Environmental Progress \& Sustainable Energy: An Official Publication of the American Institute of Chemical Engineers, 28(3), 386-396.

Bridges, D. C., \& College, A. B. A. (2011). A biological analysis of the use and benefits of chloro-s-triazine herbicides in US corn and sorghum production.

Burns, R. G., DeForest, J. L., Marxsen, J., Sinsabaugh, R. L., Stromberger, M. E., Wallenstein, M. D., ... \& Zoppini, A. (2013). Soil enzymes in a changing environment: current knowledge and future directions. Soil Biology and Biochemistry, 58, 216-234.

Cabrera, A., Cox, L., Spokas, K. A., Celis, R., Hermosín, M. C., Cornejo, J., \& Koskinen, W. C. (2011). Comparative sorption and leaching study of the herbicides fluometuron and 4-chloro-2-methylphenoxyacetic acid (MCPA) in a soil amended with biochars and other sorbents. Journal of agricultural and food chemistry, 59(23), 12550-12560.

Cao, X., Ma, L., Gao, B., \& Harris, W. (2009). Dairy-manure derived biochar effectively sorbs lead and atrazine. Environmental science \& technology, 43(9), 3285-3291.

Cao, X., \& Harris, W. (2010). Properties of dairy-manure-derived biochar pertinent to its potential use in remediation. Bioresource technology, 101(14), 5222-5228.

Caroline, A., Debode, J., Vandecasteele, B., D'Hose, T., Cremelie, P., Haegeman, A., ... \& Maes, M. (2016). Biological, physicochemical and plant health responses in lettuce and strawberry in soil or peat amended with biochar. Applied Soil Ecology, 107, 1-12.

Cayuela, M. L., Van Zwieten, L., Singh, B. P., Jeffery, S., Roig, A., \& Sánchez-Monedero, M. A. (2014). Biochar's role in mitigating soil nitrous oxide emissions: A review and metaanalysis. Agriculture, Ecosystems \& Environment, 191, 5-16.

Chan, K. Y., Van Zwieten, L., Meszaros, I., Downie, A., \& Joseph, S. (2008). Agronomic values of greenwaste biochar as a soil amendment. Soil Research, 45(8), 629-634.

Chen, B., Johnson, E. J., Chefetz, B., Zhu, L., \& Xing, B. (2005). Sorption of polar and nonpolar aromatic organic contaminants by plant cuticular materials: role of polarity and accessibility. Environmental science \& technology, 39(16), 6138-6146.

Chen, B., Zhou, D., \& Zhu, L. (2008). Transitional adsorption and partition of nonpolar and polar aromatic contaminants by biochars of pine needles with different pyrolytic temperatures. Environmental science \& technology, 42(14), 5137-5143.

Chen, B., \& Chen, Z. (2009). Sorption of naphthalene and 1-naphthol by biochars of orange peels with different pyrolytic temperatures. Chemosphere, 76(1), 127-133.

Chen, B., Yuan, M., \& Qian, L. (2012). Enhanced bioremediation of PAH-contaminated soil by immobilized bacteria with plant residue and biochar as carriers. Journal of Soils and Sediments, 12(9), 1350-1359. 
Chen, D., Yu, X., Song, C., Pang, X., Huang, J., \& Li, Y. (2016). Effect of pyrolysis temperature on the chemical oxidation stability of bamboo biochar. Bioresource technology, 218, 1303-1306.

Chen, J., Liu, X., Zheng, J., Zhang, B., Lu, H., Chi, Z., ... \& Wang, J. (2013). Biochar soil amendment increased bacterial but decreased fungal gene abundance with shifts in community structure in a slightly acid rice paddy from Southwest China. Applied Soil Ecology, 71, 33-44.

Chen, Z., Chen, B., Zhou, D., \& Chen, W. (2012). Bisolute sorption and thermodynamic behavior of organic pollutants to biomass-derived biochars at two pyrolytic temperatures. Environmental science \& technology, 46(22), 12476-12483.

Chróst, R. J., \& Krambeck, H. J. (1986). Fluorescence correction for measurements of enzyme activity in natural waters using methylumbelliferyl-substrates. Archiv für Hydrobiologie, 106(1), 79-90.

Chun, Y., Sheng, G., Chiou, C. T., \& Xing, B. (2004). Compositions and sorptive properties of crop residue-derived chars. Environmental science \& technology, 38(17), 4649-4655.

Cornelissen, G., Nurida, N. L., Hale, S. E., Martinsen, V., Silvani, L., \& Mulder, J. (2018). Fading positive effect of biochar on crop yield and soil acidity during five growth seasons in an Indonesian Ultisol. Science of the Total Environment, 634, 561-568.

Deenik, J. L., McClellan, T., Uehara, G., Antal, M. J., \& Campbell, S. (2010). Charcoal volatile matter content influences plant growth and soil nitrogen transformations. Soil Science Society of America Journal, 74(4), 1259-1270.

Delwiche, K. B., Lehmann, J., \& Walter, M. T. (2014). Atrazine leaching from biocharamended soils. Chemosphere, 95, 346-352.

de Melo Carvalho, M. T., Madari, B. E., Bastiaans, L., van Oort, P. A. J., Heinemann, A. B., da Silva, M. A. S., ... \& Meinke, H. (2013). Biochar improves fertility of a clay soil in the Brazilian Savannah: short term effects and impact on rice yield. Journal of Agriculture and Rural Development in the Tropics and Subtropics (JARTS), 114(2), 101-107.

Deng, H., Yu, H., Chen, M., \& Ge, C. (2014). Sorption of atrazine in tropical soil by biochar prepared from cassava waste. BioResources, 9(4), 6627-6643.

Ding, Y., Liu, Y., Liu, S., Li, Z., Tan, X., Huang, X., ... \& Zheng, B. (2016). Biochar to improve soil fertility. A review. Agronomy for sustainable development, 36(2), 36.

Domingues, R. R., Trugilho, P. F., Silva, C. A., de Melo, I. C. N., Melo, L. C., Magriotis, Z. M., \& Sanchez-Monedero, M. A. (2017). Properties of biochar derived from wood and high-nutrient biomasses with the aim of agronomic and environmental benefits. PloS one, 12(5).

Downie, A., Crosky, A., \& Munroe, P. (2009). Physical properties of biochar. Biochar for environmental management: Science and technology, 1. 
Dunlop, S. J., Arbestain, M. C., Bishop, P. A., \& Wargent, J. J. (2015). Closing the loop: use of biochar produced from tomato crop green waste as a substrate for soilless, hydroponic tomato production. HortScience, 50(10), 1572-1581.

Elad, Y., David, D. R., Harel, Y. M., Borenshtein, M., Kalifa, H. B., Silber, A., \& Graber, E. R. (2010). Induction of systemic resistance in plants by biochar, a soil-applied carbon sequestering agent. Phytopathology, 100(9), 913-921.

Elmer, W. H., \& Pignatello, J. J. (2011). Effect of biochar amendments on mycorrhizal associations and Fusarium crown and root rot of asparagus in replant soils. Plant Disease, 95(8), 960-966.

Ezawa, T., Yamamoto, K., \& Yoshida, S. (2002). Enhancement of the effectiveness of indigenous arbuscular mycorrhizal fungi by inorganic soil amendments. Soil Science and Plant Nutrition, 48(6), 897-900.

Fang, Q., Chen, B., Lin, Y., \& Guan, Y. (2014). Aromatic and hydrophobic surfaces of wood-derived biochar enhance perchlorate adsorption via hydrogen bonding to oxygencontaining organic groups. Environmental science \& technology, 48(1), 279-288.

Fidel, R. B., Laird, D. A., \& Parkin, T. B. (2019). Effect of biochar on soil greenhouse gas emissions at the laboratory and field scales. Soil Systems, 3(1), 8.

Gai, X., Wang, H., Liu, J., Zhai, L., Liu, S., Ren, T., \& Liu, H. (2014). Effects of feedstock and pyrolysis temperature on biochar adsorption of ammonium and nitrate. PloS one, $9(12)$.

García-Jaramillo, M., Cox, L., Cornejo, J., \& Hermosín, M. C. (2014). Effect of soil organic amendments on the behavior of bentazone and tricyclazole. Science of the total environment, 466, 906-913.

Gaskin, J. W., Steiner, C., Harris, K., Das, K. C., \& Bibens, B. (2008). Effect of lowtemperature pyrolysis conditions on biochar for agricultural use. Transactions of the ASABE, 51(6), 2061-2069.

Gaskin, J. W., Speir, R. A., Harris, K., Das, K. C., Lee, R. D., Morris, L. A., \& Fisher, D. S. (2010). Effect of peanut hull and pine chip biochar on soil nutrients, corn nutrient status, and yield. Agronomy Journal, 102(2), 623-633.

Gaur, A., \& Adholeya, A. (2004). Prospects of arbuscular mycorrhizal fungi in phytoremediation of heavy metal contaminated soils. Current Science, 528-534.

Ghosh, R. K., \& Singh, N. (2013). Adsorption-desorption of metolachlor and atrazine in Indian soils: effect of fly ash amendment. Environmental monitoring and assessment, 185(2), 1833-1845.

Glaser, B., Haumaier, L., Guggenberger, G., \& Zech, W. (2001). The'Terra Preta'phenomenon: a model for sustainable agriculture in the humid tropics. Naturwissenschaften, 88(1), 37-41. 
Glaser, B., Parr, M., Braun, C., \& Kopolo, G. (2009). Biochar is carbon negative. Nature Geoscience, 2(1), 2-2.

Graber, E. R., Harel, Y. M., Kolton, M., Cytryn, E., Silber, A., David, D. R., \& Elad, Y. (2010). Biochar impact on development and productivity of pepper and tomato grown in fertigated soilless media. Plant and soil, 337(1-2), 481-496.

Graber, E. R., Tsechansky, L., Lew, B., \& Cohen, E. (2014). Reducing capacity of water extracts of biochars and their solubilization of soil M $\mathrm{n}$ and F e. European Journal of Soil Science, 65(1), 162-172.

Gravel, V., Dorais, M., \& Ménard, C. (2013). Organic potted plants amended with biochar: its effect on growth and Pythium colonization. Canadian Journal of Plant Science, 93(6), 1217-1227.

Grube, A. H., Donaldson, D., \& Kiely, T. (2004). Pesticides industry sales and usage: 2000 and 2001 market estimates. Biological and Economic Analysis Division, US Environmental Protection Agency.

Giudicianni, P., Cardone, G., \& Ragucci, R. (2013). Cellulose, hemicellulose and lignin slow steam pyrolysis: Thermal decomposition of biomass components mixtures. Journal of Analytical and Applied Pyrolysis, 100, 213-222.

Gundale, M. J., \& DeLuca, T. H. (2007). Charcoal effects on soil solution chemistry and growth of Koeleria macrantha in the ponderosa pine/Douglas-fir ecosystem. Biology and Fertility of soils, 43(3), 303-311.

Guo, Y., Niu, G., Starman, T., Volder, A., \& Gu, M. (2018). Poinsettia growth and development response to container root substrate with biochar. Horticulturae, 4(1), 1.

Hao, F., Zhao, X., Ouyang, W., Lin, C., Chen, S., Shan, Y., \& Lai, X. (2013). Molecular structure of corncob-derived Biochars and the mechanism of Atrazine sorption. Agronomy Journal, 105(3), 773-782.

Hayes, T. B., Collins, A., Lee, M., Mendoza, M., Noriega, N., Stuart, A. A., \& Vonk, A. (2002). Hermaphroditic, demasculinized frogs after exposure to the herbicide atrazine at low ecologically relevant doses. Proceedings of the National Academy of Sciences, 99(8), 5476-5480.

Hayes, T. B., Stuart, A. A., Mendoza, M., Collins, A., Noriega, N., Vonk, A., \& Kpodzo, D. (2006). Characterization of atrazine-induced gonadal malformations in African clawed frogs (Xenopus laevis) and comparisons with effects of an androgen antagonist (cyproterone acetate) and exogenous estrogen (17ß-estradiol): support for the demasculinization/feminization hypothesis. Environmental health perspectives, 114 (Suppl 1), 134-141.

Hayes, T. B., Khoury, V., Narayan, A., Nazir, M., Park, A., Brown, T., \& Gallipeau, S. (2010). Atrazine induces complete feminization and chemical castration in male African clawed frogs (Xenopus laevis). Proceedings of the National Academy of Sciences, 107(10), 4612-4617. 
Hoppe, H. G. (1993). Use of fluorogenic model substrates for extracellular enzyme activity (EEA) measurement of bacteria. Handbook of methods in aquatic microbial ecology, 423431.

Houben, D., Evrard, L., \& Sonnet, P. (2013). Mobility, bioavailability and pH-dependent leaching of cadmium, zinc and lead in a contaminated soil amended with biochar. Chemosphere, 92(11), 1450-1457.

Huang, H., Zhang, C., Zhang, P., Cao, M., Xu, G., Wu, H., \& Rong, Q. (2018). Effects of biochar amendment on the sorption and degradation of atrazine in different soils. Soil and Sediment Contamination: An International Journal, 27(8), 643-657.

Ippolito, J. A., Laird, D. A., \& Busscher, W. J. (2012). Environmental benefits of biochar. Journal of environmental quality, 41(4), 967-972.

Ishii, T., \& Kadoya, K. (1994). Effects of charcoal as a soil conditioner on citrus growth and vesicular-arbuscular mycorrhizal development. Journal of the Japanese Society for Horticultural Science, 63(3), 529-535.

Jaafar, N. M., Clode, P. L., \& Abbott, L. K. (2014). Microscopy observations of habitable space in biochar for colonization by fungal hyphae from soil. Journal of Integrative Agriculture, 13(3), 483-490.

Jeffery, S., Verheijen, F. G., van der Velde, M., \& Bastos, A. C. (2011). A quantitative review of the effects of biochar application to soils on crop productivity using metaanalysis. Agriculture, ecosystems \& environment, 144(1), 175-187.

Jindo, K., Mizumoto, H., Sawada, Y., Sánchez-Monedero, M. Á., \& Sonoki, T. (2014). Physical and chemical characterization of biochars derived from different agricultural residues.

Johnson, C. D., \& Decoteau, D. R. (1996). Nitrogen and potassium fertility affects Jalapeño pepper plant growth, pod yield, and pungency. HortScience, 31(7), 1119-1123.

Johnson, R., Crafton, R. E., \& Upton, H. F. (2017). Invasive species: major laws and the role of selected federal agencies. Washington, DC: Congressional Research Service.

Jones, D. L., Murphy, D. V., Khalid, M., Ahmad, W., Edwards-Jones, G., \& DeLuca, T. H. (2011). Short-term biochar-induced increase in soil CO2 release is both biotically and abiotically mediated. Soil Biology and Biochemistry, 43(8), 1723-1731.

Jones, D. L., Rousk, J., Edwards-Jones, G., DeLuca, T. H., \& Murphy, D. V. (2012). Biochar-mediated changes in soil quality and plant growth in a three year field trial. Soil Biology and Biochemistry, 45, 113-124.

Jung, C., Park, J., Lim, K. H., Park, S., Heo, J., Her, N., ... \& Yoon, Y. (2013). Adsorption of selected endocrine disrupting compounds and pharmaceuticals on activated biochars. Journal of Hazardous Materials, 263, 702-710. 
Kammann, C., Ratering, S., Eckhard, C., \& Müller, C. (2012). Biochar and hydrochar effects on greenhouse gas (carbon dioxide, nitrous oxide, and methane) fluxes from soils. Journal of environmental quality, 41(4), 1052-1066.

Kasozi, G. N., Zimmerman, A. R., Nkedi-Kizza, P., \& Gao, B. (2010). Catechol and humic acid sorption onto a range of laboratory-produced black carbons (biochars). Environmental science \& technology, 44(16), 6189-6195.

Keiluweit, M., Nico, P. S., Johnson, M. G., \& Kleber, M. (2010). Dynamic molecular structure of plant biomass- derived black carbon (biochar). Environmental science \& technology, 44(4), 1247-1253.

Khodadad, C. L., Zimmerman, A. R., Green, S. J., Uthandi, S., \& Foster, J. S. (2011). Taxaspecific changes in soil microbial community composition induced by pyrogenic carbon amendments. Soil Biology and Biochemistry, 43(2), 385-392.

Khorram, M. S., Zhang, Q., Lin, D., Zheng, Y., Fang, H., \& Yu, Y. (2016). Biochar: a review of its impact on pesticide behavior in soil environments and its potential applications. Journal of environmental sciences, 44, 269-279.

Koelmans, A. A., Meulman, B., Meijer, T., \& Jonker, M. T. (2009). Attenuation of polychlorinated biphenyl sorption to charcoal by humic acids. Environmental science \& technology, 43(3), 736-742.

Kolton, M., Harel, Y. M., Pasternak, Z., Graber, E. R., Elad, Y., \& Cytryn, E. (2011). Impact of biochar application to soil on the root-associated bacterial community structure of fully developed greenhouse pepper plants. Applied and environmental microbiology, 77(14), 4924-4930.

Komnitsas, K., Zaharaki, D., Bartzas, G., Kaliakatsou, G., \& Kritikaki, A. (2016). Efficiency of pecan shells and sawdust biochar on $\mathrm{Pb}$ and $\mathrm{Cu}$ adsorption. Desalination and Water Treatment, 57(7), 3237-3246.

Krutz, L. J., Senseman, S. A., McInnes, K. J., Zuberer, D. A., \& Tierney, D. P. (2003). Adsorption and desorption of atrazine, desethylatrazine, deisopropylatrazine, and hydroxyatrazine in vegetated filter strip and cultivated soil. Journal of agricultural and food chemistry, 51(25), 7379-7384.

Laird, D. A., Brown, R. C., Amonette, J. E., \& Lehmann, J. (2009). Review of the pyrolysis platform for coproducing bio-oil and biochar. Biofuels, bioproducts and biorefining, 3(5), 547-562.

Lal, R., \& Bruce, J. P. (1999). The potential of world cropland soils to sequester C and mitigate the greenhouse effect. Environmental Science \& Policy, 2(2), 177-185.

Lammirato, C., Miltner, A., \& Kaestner, M. (2011). Effects of wood char and activated carbon on the hydrolysis of cellobiose by $\beta$-glucosidase from Aspergillus niger. Soil Biology and Biochemistry, 43(9), 1936-1942. 
Lasserre, J. P., Fack, F., Revets, D., Planchon, S., Renaut, J., Hoffmann, L., \& Bohn, T. (2009). Effects of the endocrine disruptor's atrazine and PCB 153 on the protein expression of MCF-7 human cells. Journal of proteome research, 8(12), 5485-5496.

Lehmann, J., Gaunt, J., \& Rondon, M. (2006). Bio-char sequestration in terrestrial ecosystems-a review. Mitigation and adaptation strategies for global change, 11(2), 403427.

Lehmann, J., \& Joseph, S. (2009). Biochar for environmental management: an introduction. Biochar for environmental management: Science and technology, 1, 1-12.

Lehmann, J., Rillig, M. C., Thies, J., Masiello, C. A., Hockaday, W. C., \& Crowley, D. (2011). Biochar effects on soil biota-a review. Soil biology and biochemistry, 43(9), 18121836.

Lentz, R. D., \& Ippolito, J. A. (2012). Biochar and manure affect calcareous soil and corn silage nutrient concentrations and uptake. Journal of environmental quality, 41(4), 10331043.

Li, X., Shen, Q., Zhang, D., Mei, X., Ran, W., Xu, Y., \& Yu, G. (2013). Functional groups determine biochar properties ( $\mathrm{pH}$ and EC) as studied by two-dimensional $13 \mathrm{C} \mathrm{NMR}$ correlation spectroscopy. PLoS One, 8(6), e65949.

Lima, D. L., Silva, C. P., Schneider, R. J., \& Esteves, V. I. (2011). Development of an ELISA procedure to study sorption of atrazine onto a sewage sludge-amended luvisol soil. Talanta, 85(3), 1494-1499.

Liu, R., Gu, M., Huang, L., Yu, F., Jung, S. K., \& Choi, H. S. (2019). Effect of pine wood biochar mixed with two types of compost on growth of bell pepper (Capsicum annuum L.). Horticulture, Environment, and Biotechnology, 60(3), 313-319.

Liu, S., Manson, J. E., Lee, I. M., Cole, S. R., Hennekens, C. H., Willett, W. C., \& Buring, J. E. (2000). Fruit and vegetable intake and risk of cardiovascular disease: the Women's Health Study. The American journal of clinical nutrition, 72(4), 922-928.

Liu, Z., Clay, S. A., Clay, D. E., \& Harper, S. S. (1995). Ammonia fertilizer influences atrazine adsorption-desorption characteristics. Journal of Agricultural and Food Chemistry, 43(3), 815-819.

Maia, C. M. B., Madari, B. E., \& Novotny, E. H. (2011). Advances in biochar research in Brazil. Embrapa Solos-Artigo em periódico indexado (ALICE).

Major, J., Rondon, M., Molina, D., Riha, S. J., \& Lehmann, J. (2010). Maize yield and nutrition during 4 years after biochar application to a Colombian savanna oxisol. Plant and soil, 333(1-2), 117-128.

Mandal, A., \& Singh, N. (2017). Optimization of atrazine and imidacloprid removal from water using biochars: Designing single or multi-staged batch adsorption systems. International journal of hygiene and environmental health, 220(3), 637-645. 
Mandal, A., Singh, N., \& Purakayastha, T. J. (2017). Characterization of pesticide sorption behaviour of slow pyrolysis biochars as low cost adsorbent for atrazine and imidacloprid removal. Science of the Total Environment, 577, 376-385.

Masto, R. E., Kumar, S., Rout, T. K., Sarkar, P., George, J., \& Ram, L. C. (2013). Biochar from water hyacinth (Eichornia crassipes) and its impact on soil biological activity. Catena, 111, 64-71.

Marschner, P., Kandeler, E., \& Marschner, B. (2003). Structure and function of the soil microbial community in a long-term fertilizer experiment. Soil Biology and Biochemistry, 35(3), 453-461.

Marstorp, H., Guan, X., \& Gong, P. (2000). Relationship between dsDNA, chloroform labile $\mathrm{C}$ and ergosterol in soils of different organic matter contents and $\mathrm{pH}$. Soil Biology and Biochemistry, 32(6), 879-882.

McGonigle, T. P., Miller, M. H., Evans, D. G., Fairchild, G. L., \& Swan, J. A. (1990). A new method which gives an objective measure of colonization of roots by vesiculararbuscular mycorrhizal fungi. New phytologist, 115(3), 495-501.

McHenry, M. P. (2010). Carbon-based stock feed additives: a research methodology that explores ecologically delivered $\mathrm{C}$ biosequestration, alongside live weights, feed use efficiency, soil nutrient retention, and perennial fodder plantations. Journal of the Science of Food and Agriculture, 90(2), 183-187.

Mesa, A. C., \& Spokas, K. A. (2011). Impacts of biochar (black carbon) additions on the sorption and efficacy of herbicides. Herbicides and environment, 13, 315-340.

Moreno-González, R., Campillo, J. A., García, V., \& León, V. M. (2013). Seasonal input of regulated and emerging organic pollutants through surface watercourses to a Mediterranean coastal lagoon. Chemosphere, 92(3), 247-257.

Mylavarapu, R., Nair, V., \& Morgan, K. (2013). An Introduction to Biochars and Their Uses in Agriculture. EDIS, 2013(8).

NASERI, S., Dehghani, M., Amin, S., NADAFI, K., \& Zamanian, Z. (2009). Fate of atrazine in the agricultural soil of corn fields in Fars province of Iran.

Nomura, A. M., Wilkens, L. R., Murphy, S. P., Hankin, J. H., Henderson, B. E., Pike, M. C., \& Kolonel, L. N. (2008). Association of vegetable, fruit, and grain intakes with colorectal cancer: the Multiethnic Cohort Study. The American journal of clinical nutrition, 88(3), 730-737.

Novak, J. M., Lima, I., Xing, B., Gaskin, J. W., Steiner, C., Das, K. C., \& Schomberg, H. (2009). Characterization of designer biochar produced at different temperatures and their effects on a loamy sand. Annals of Environmental Science.

Novak, J. M., \& Busscher, W. J. (2013). Selection and use of designer biochars to improve characteristics of southeastern USA Coastal Plain degraded soils. In Advanced biofuels and bioproducts, 69-96. 
Obia, A., Mulder, J., Martinsen, V., Cornelissen, G., \& Børresen, T. (2016). In situ effects of biochar on aggregation, water retention and porosity in light-textured tropical soils. Soil and Tillage Research, 155, 35-44.

O’neill, B., Grossman, J., Tsai, M., Gomes, J. E., Lehmann, J., Peterson, J., ... \& Thies, J. E. (2009). Bacterial community composition in Brazilian Anthrosols and adjacent soils characterized using culturing and molecular identification. Microbial Ecology, 58(1), 2335 .

Organisation for Economic Co-operation and Development. (2000). Test No. 106: Adsorption--Desorption Using a Batch Equilibrium Method. OECD publishing.

Ozores-Hampton, M., \& McAvoy, G. (2014). Jalapeño and Other Hot Pepper Varieties for Florida1. Serie HS1241, Department of Horticultural Science, UF/IFAS Extension, University of Florida, Gainesville, FL.

Pan, M. (2020). Biochar Adsorption of Antibiotics and its Implications to Remediation of Contaminated Soil. Water, Air, \& Soil Pollution, 231, 1-15.

Paz-Ferreiro, J., Gascó, G., Gutiérrez, B., \& Méndez, A. (2012). Soil biochemical activities and the geometric mean of enzyme activities after application of sewage sludge and sewage sludge biochar to soil. Biology and fertility of soils, 48(5), 511-517.

Pietikäinen, J., Kiikkilä, O., \& Fritze, H. (2000). Charcoal as a habitat for microbes and its effect on the microbial community of the underlying humus. Oikos, 89(2), 231-242.

Pignatello, J. J., Kwon, S., \& Lu, Y. (2006). Effect of natural organic substances on the surface and adsorptive properties of environmental black carbon (char): attenuation of surface activity by humic and fulvic acids. Environmental science \& technology, 40(24), 7757-7763.

Qiu, Y., Xiao, X., Cheng, H., Zhou, Z., \& Sheng, G. D. (2009). Influence of environmental factors on pesticide adsorption by black carbon: $\mathrm{pH}$ and model dissolved organic matter. Environmental Science \& Technology, 43(13), 4973-4978.

Quilliam, R. S., Glanville, H. C., Wade, S. C., \& Jones, D. L. (2013). Life in the 'charosphere'-Does biochar in agricultural soil provide a significant habitat for microorganisms?. Soil Biology and Biochemistry, 65, 287-293.

Rafiq, M. K., Bachmann, R. T., Rafiq, M. T., Shang, Z., Joseph, S., \& Long, R. (2016). Influence of pyrolysis temperature on physico-chemical properties of corn stover (Zea mays L.) biochar and feasibility for carbon capture and energy balance. PloS one, 11(6), e0156894.

Raman, S., Krishna, M., \& Rao, P. C. (1988). Adsorption-desorption of atrazine on four soils of Hyderabad. Water, $\quad$ Air, and Soil Pollution, 40(1-2), 177-184.

Ronsse, F., Van Hecke, S., Dickinson, D., \& Prins, W. (2013). Production and characterization of slow pyrolysis biochar: influence of feedstock type and pyrolysis conditions. Gcb Bioenergy, 5(2), 104-115. 
Rousk, J., Brookes, P. C., \& Bååth, E. (2009). Contrasting soil pH effects on fungal and bacterial growth suggest functional redundancy in carbon mineralization. Applied and Environmental Microbiology, 75(6), 1589-1596.

Saito, M., \& Marumoto, T. (2002). Inoculation with arbuscular mycorrhizal fungi: the status quo in Japan and the future prospects. In Diversity and Integration in Mycorrhizas (pp. 273-279). Springer, Dordrecht.

Schmidt, M. W., \& Noack, A. G. (2000). Black carbon in soils and sediments: analysis, distribution, implications, and current challenges. Global biogeochemical cycles, 14(3), 777-793.

Schnell, R. W., Vietor, D. M., Provin, T. L., Munster, C. L., \& Capareda, S. (2012). Capacity of biochar application to maintain energy crop productivity: soil chemistry, sorghum growth, and runoff water quality effects. Journal of environmental quality, 41(4), 1044-1051.

Schulz, H., \& Glaser, B. (2012). Effects of biochar compared to organic and inorganic fertilizers on soil quality and plant growth in a greenhouse experiment. Journal of Plant Nutrition and Soil Science, 175(3), 410-422.

Scialabba, N. E. H., \& Müller-Lindenlauf, M. (2010). Organic agriculture and climate change. Renewable Agriculture and Food Systems, 25(2), 158-169.

Shaaban, A., Se, S. M., Dimin, M. F., Juoi, J. M., Husin, M. H. M., \& Mitan, N. M. M. (2014). Influence of heating temperature and holding time on biochars derived from rubber wood sawdust via slow pyrolysis. Journal of Analytical and Applied Pyrolysis, 107, 31-39.

Sinsabaugh, R. L., Findlay, S., Franchini, P., \& Fischer, D. (1997). Enzymatic analysis of riverine bacterioplankton production. Limnology and oceanography, 42(1), 29-38.

Sohi, S. P., Krull, E., Lopez-Capel, E., \& Bol, R. (2010). A review of biochar and its use and function in soil. In Advances in agronomy (Vol. 105, pp. 47-82). Academic Press.

Solaiman, Z. M., Murphy, D. V., \& Abbott, L. K. (2012). Biochars influence seed germination and early growth of seedlings. Plant and soil, 353(1-2), 273-287.

Sombroek, W. I. M., Ruivo, M. D. L., Fearnside, P. M., Glaser, B., \& Lehmann, J. (2003). Amazonian dark earths as carbon stores and sinks. In Amazonian dark earths (pp. 125139). Springer, Dordrecht.

Song, W., \& Guo, M. (2012). Quality variations of poultry litter biochar generated at different pyrolysis temperatures. Journal of analytical and applied pyrolysis, 94, 138-145.

Spokas, K. A., Koskinen, W. C., Baker, J. M., \& Reicosky, D. C. (2009). Impacts of woodchip biochar additions on greenhouse gas production and sorption/degradation of two herbicides in a Minnesota soil. Chemosphere, 77(4), 574-581.

Spokas, K. A., Cantrell, K. B., Novak, J. M., Archer, D. W., Ippolito, J. A., Collins, H. P., \& Lentz, R. D. (2012). Biochar: a synthesis of its agronomic impact beyond carbon sequestration. Journal of environmental quality, 41(4), 973-989. 
Steiner, C., Das, K. C., Garcia, M., Förster, B., \& Zech, W. (2008). Charcoal and smoke extract stimulate the soil microbial community in a highly weathered xanthic Ferralsol. Pedobiologia, 51(5-6), 359-366.

Sugumaran, P., \& Seshadri, S. (2009). Evaluation of selected biomass for charcoal production. Journal of Scientific and Industrial Research, 68(8), 719-723

Sugumaran, P., Susan, V. P., Ravichandran, P., \& Seshadri, S. (2012). Production and characterization of activated carbon from banana empty fruit bunch and Delonix regia fruit pod. Journal of Sustainable Energy \& Environment, 3(3), 125-132.

Sun, K., Gao, B., Zhang, Z., Zhang, G., Zhao, Y., \& Xing, B. (2010). Sorption of atrazine and phenanthrene by organic matter fractions in soil and sediment. Environmental Pollution, 158(12), 3520-3526.

Sun, K., Kang, M., Zhang, Z., Jin, J., Wang, Z., Pan, Z., \& Xing, B. (2013). Impact of deashing treatment on biochar structural properties and potential sorption mechanisms of phenanthrene. Environmental science \& technology, 47(20), 11473-11481.

Sun, Z., Bruun, E. W., Arthur, E., de Jonge, L. W., Moldrup, P., Hauggaard-Nielsen, H., \& Elsgaard, L. (2014). Effect of biochar on aerobic processes, enzyme activity, and crop yields in two sandy loam soils. Biology and Fertility of Soils, 50(7), 1087-1097.

Tammeorg, P., Simojoki, A., Mäkelä, P., Stoddard, F. L., Alakukku, L., \& Helenius, J. (2014). Short-term effects of biochar on soil properties and wheat yield formation with meat bone meal and inorganic fertiliser on a boreal loamy sand. Agriculture, Ecosystems \& Environment, 191, 108-116.

Teixidó, M., Pignatello, J. J., Beltrán, J. L., Granados, M., \& Peccia, J. (2011). Speciation of the ionizable antibiotic sulfamethazine on black carbon (biochar). Environmental science \& technology, 45(23), 10020-10027.

Thies, J. E., \& Rillig, M. C. (2009). Characteristics of biochar: biological properties. Biochar for environmental management: Science and technology, 1, 85-105.

United States Environmental Protection Agency (US-EPA) (2009). Drinking Water Contaminates, URL: http://water.epa.gov/drink/contaminants.

University of Florida-IFAS Center for Aquatic \& Invasive Plants. (2012). Florida noxious weed list. Rule 5B-57.007.

Van Zwieten, L., Singh, B., Joseph, S., Kimber, S., Cowie, A., \& Chan, K. Y. (2009). Biochar and emissions of non- $\mathrm{CO}_{2}$ greenhouse gases from soil. Biochar for environmental management: science and technology, 1, 227-250.

Vaughn, S. F., Eller, F. J., Evangelista, R. L., Moser, B. R., Lee, E., Wagner, R. E., \& Peterson, S. C. (2015). Evaluation of biochar-anaerobic potato digestate mixtures as renewable components of horticultural potting media. Industrial Crops and Products, 65, 467-471. 
Velez, T. I., Moonilall, N. I., Reed, S., Jayachandran, K., \& Scinto, L. J. (2018). Impact of Melaleuca quinquenervia Biochar on Phaseolus vulgaris Growth, Soil Nutrients, and Microbial Gas Flux. Journal of environmental quality, 47(6), 1487-1495.

Waldrop, M. P., Balser, T. C., \& Firestone, M. K. (2000). Linking microbial community composition to function in a tropical soil. Soil biology and biochemistry, 32(13), 18371846.

Warnock, D. D., Lehmann, J., Kuyper, T. W., \& Rillig, M. C. (2007). Mycorrhizal responses to biochar in soil-concepts and mechanisms. Plant and soil, 300(1-2), 9-20.

Warnock, D. D., Mummey, D. L., McBride, B., Major, J., Lehmann, J., \& Rillig, M. C. (2010). Influences of non-herbaceous biochar on arbuscular mycorrhizal fungal abundances in roots and soils: results from growth-chamber and field experiments. Applied Soil Ecology, 46(3), 450-456.

Weidner, S., Koller, R., Latz, E., Kowalchuk, G., Bonkowski, M., Scheu, S., \& Jousset, A. (2015). Bacterial diversity amplifies nutrient-based plant-soil feedbacks. Functional Ecology, 29(10), 1341-1349.

Wu, F., Jia, Z., Wang, S., Chang, S. X., \& Startsev, A. (2013). Contrasting effects of wheat straw and its biochar on greenhouse gas emissions and enzyme activities in a Chernozemic soil. Biology and Fertility of Soils, 49(5), 555-565.

Xiao, F., \& Pignatello, J. J. (2015). Interactions of triazine herbicides with biochar: Steric and electronic effects. Water research, 80, 179-188.

Yang, Y., Shu, L., Wang, X., Xing, B., \& Tao, S. (2011). Impact of de-ashing humic acid and humin on organic matter structural properties and sorption mechanisms of phenanthrene. Environmental science \& technology, 45(9), 3996-4002.

Yao, F. X., Arbestain, M. C., Virgel, S., Blanco, F., Arostegui, J., Maciá-Agulló, J. A., \& Macìas, F. (2010). Simulated geochemical weathering of a mineral ash-rich biochar in a modified Soxhlet reactor. Chemosphere, 80(7), 724-732.

Yu, P., Huang, L., Li, Q., Lima, I. M., White, P. M., \& Gu, M. (2020). Effects of mixed hardwood and sugarcane biochar as bark-based substrate substitutes on container plants production and nutrient leaching. Agronomy, 10(2), 15.

Yu, X. Y., Ying, G. G., \& Kookana, R. S. (2006). Sorption and desorption behaviors of diuron in soils amended with charcoal. Journal of agricultural and food chemistry, 54(22), 8545-8550.

Yu, X. Y., Mu, C. L., Gu, C., Liu, C., \& Liu, X. J. (2011). Impact of woodchip biochar amendment on the sorption and dissipation of pesticide acetamiprid in agricultural soils. Chemosphere, 85(8), 1284-1289.

Zackrisson, O., Nilsson, M. C., \& Wardle, D. A. (1996). Key ecological function of charcoal from wildfire in the Boreal forest. Oikos, 10-19. 
Zhao, L., Cao, X., Mašek, O., \& Zimmerman, A. (2013). Heterogeneity of biochar properties as a function of feedstock sources and production temperatures. Journal of hazardous materials, 256, 1-9.

Zhang, H., Lin, K., Wang, H., \& Gan, J. (2010). Effect of Pinus radiata derived biochars on soil sorption and desorption of phenanthrene. Environmental Pollution, 158(9), 28212825.

Zhang, P., Sun, H., Yu, L., \& Sun, T. (2013). Adsorption and catalytic hydrolysis of carbaryl and atrazine on pig manure-derived biochars: impact of structural properties of biochars. Journal of hazardous materials, 244, 217-224.

Zhang, P., Sun, H., Ren, C., Min, L., \& Zhang, H. (2018). Sorption mechanisms of neonicotinoids on biochars and the impact of deashing treatments on biochar structure and neonicotinoids sorption. Environmental pollution, 234, 812-820.

Zhao, S. X., Ta, N., \& Wang, X. D. (2017). Effect of temperature on the structural and physicochemical properties of biochar with apple tree branches as feedstock material. Energies, 10(9), 1293.

Zhu, D., Kwon, S., \& Pignatello, J. J. (2005). Adsorption of single-ring organic compounds to wood charcoals prepared under different thermochemical conditions. Environmental science \& technology, 39(11), 3990-3998.

Zornoza, R., Moreno-Barriga, F., Acosta, J. A., Muñoz, M. A., \& Faz, A. (2016). Stability, nutrient availability and hydrophobicity of biochars derived from manure, crop residues, and municipal solid waste for their use as soil amendments. Chemosphere, 144, 122-130. 
VITA

\section{SHAGUFTA GAFFAR}

Born, Bangladesh

$2004-2009$

B.Sc., Soil, Water and Environment

Department of Soil, Water and Environment

University of Dhaka

Dhaka, Bangladesh

$2009-2011$

M.S., Soil, Water and Environment

Department of Soil, Water and Environment

University of Dhaka

Dhaka, Bangladesh

$2015-2018$

M.S., Environmental Studies

Department of Earth and Environment

Florida International University

Miami, Florida, USA

$2015-2020$

Ph.D., Earth Systems Science

Department of Earth and Environment

Florida International University

Miami, Florida, USA

Graduate Teaching Assistant

Department of Earth and Environment

Florida International University

Miami, Florida, USA

2019

L. Russell Norton Memorial Fellowship

Dade County AGRI Council, INC. Awards

\section{PUBLICATIONS AND PRESENTATIONS}

Gaffar, S., Ferdous, M. J., Begum, A., \& Ullah, S. M. (2014). Transfer of natural radionuclides from soil to plants in North Western parts of Dhaka. Malaysian Journal of Soil Science, 18, 61-74.

Gaffar, S., Dautel, J., Khadka, G., \& Jayachandran, K. N. (2017, October). Management of South Florida Invasive Plants through Biochar Production. In ASA, CSSA and SSSA International Annual Meetings. ASA-CSSA-SSSA. 
Gaffar, S. (2019, January). Effects of Different Biochars on the Adsorption and Desorption of Atrazine. In SSSA International Soils Meeting. ASA, CSSA, and SSSA. $3^{\text {rd }}$ Place Presentation.

Gaffar, S. (2019, November). Effect of Different Biochars on Plant Growth, Soil Microbes and Enzyme Activity. In ASA, CSSA and SSSA International Annual Meetings (2019). ASA, CSSA, and SSSA.

Gaffar, S., Dattamudi, S., Baboukani, A., Chanda, S., Watts, D., Novak, J., Wang, C., \& Jayachandran, J. (2020). Physiochemical Characterization of Six Biochar Feedstocks and Their Effects on the Sorption Behavior of Atrazine. Soil Syst. (Submitted).

Gaffar, S., Riquelme, C., \& Jayachandran, J. Investigating the Effects of Twelve Different Biochars on the Growth of Capsicum annuum 'Jalapeno', Soil Microbial Population, and Enzyme Activity. (Awaiting submission). 